\title{
Platinum-Catalyzed Asymmetric Alkylation of Secondary Phosphines: \\ Enantioselective Synthesis of P-Stereogenic Phosphines
}

Corina Scriban and David S. Glueck

6128 Burke Laboratory, Department of Chemistry, Dartmouth College, Hanover NH, 03755

\section{Supporting Information}

Experimental Section Unless otherwise noted, all reactions and manipulations were performed in dry glassware under a nitrogen atmosphere at $20^{\circ} \mathrm{C}$ in a dry box or using standard Schlenk techniques. Petroleum ether (bp 38-53 ${ }^{\circ} \mathrm{C}$ ), ether, THF, toluene, and $\mathrm{CH}_{2} \mathrm{Cl}_{2}$ were dried using columns of activated alumina. ${ }^{1}$ NMR spectra were recorded using Varian 300 or $500 \mathrm{MHz}$ spectrometers. ${ }^{1} \mathrm{H}$ and ${ }^{13} \mathrm{C}$ NMR chemical shifts are reported vs $\mathrm{Me}_{4} \mathrm{Si}$ and were determined by reference to the residual ${ }^{1} \mathrm{H}$ and ${ }^{13} \mathrm{C}$ solvent peaks. ${ }^{31} \mathrm{P}$ NMR chemical shifts are reported $\mathrm{vs}_{3} \mathrm{PO}_{4}(85 \%)$ used as an external reference. Coupling constants are reported in $\mathrm{Hz}$ as absolute values. Unless indicated, peaks in NMR spectra are singlets. IR spectra were obtained on $\mathrm{KBr}$ pellets and are reported in $\mathrm{cm}^{-1}$. Elemental analyses were provided by Schwarzkopf Microanalytical Laboratory or Quantitative Technologies Inc. Mass spectra were recorded at the University of Illinois Urbana-Champaign.

Reagents were from commercial suppliers, except for these compounds, which were made by the literature procedures: $\mathrm{Pt}(\mathrm{COD})(\mathrm{Ph}) \mathrm{Cl})(\mathrm{COD}=$ cyclooctadiene $),{ }^{2} \mathrm{Pt}((\mathrm{R}, \mathrm{R})-\mathrm{Me}-\mathrm{Duphos}) \mathrm{Cl}_{2},{ }^{3} \mathrm{Pt}((\mathrm{R}, \mathrm{R})-$ Me-Duphos) $\mathrm{I}_{2}$ and $\operatorname{Pt}((\mathrm{R}, \mathrm{R})-\mathrm{Me}-\mathrm{Duphos})(\mathrm{Ph})(\mathrm{Cl}),{ }^{4} \mathrm{Pt}((\mathrm{R}, \mathrm{R})-\mathrm{Me}-\mathrm{Duphos})(\mathrm{Me})(\mathrm{Cl}){ }^{5} \quad \mathrm{Pt}(\mathrm{R}-\mathrm{Tol}-$ Binap) $(\mathrm{Me})(\mathrm{Cl}){ }^{6} \quad(\mathrm{~S})-\left\{\mathrm{Pd}\left[\mathrm{NMe}_{2} \mathrm{CH}(\mathrm{Me}) \mathrm{C}_{6} \mathrm{H}_{4}\right](\mathrm{Cl})\right\}_{2} \quad$ and $\quad(\mathrm{S})-\left\{\mathrm{Pd}\left[\mathrm{NMe}_{2} \mathrm{CH}(\mathrm{Me}) \mathrm{C}_{10} \mathrm{H}_{6}\right](\mathrm{Cl})\right\}_{2},{ }^{7}$ $\mathrm{Pd}((\mathrm{R}, \mathrm{R})-\mathrm{Me}-\mathrm{Duphos})\left(\mathrm{C}_{6} \mathrm{~F}_{5}\right)(\mathrm{I}),{ }^{8} \mathrm{PHMe}(\mathrm{Is})\left(\mathrm{Is}=2,4,6-(i-\mathrm{Pr})_{3} \mathrm{C}_{6} \mathrm{H}_{2}\right),{ }^{9}$ and $\mathrm{PH}(\mathrm{Ph})(o-\mathrm{An}) .{ }^{10} \mathrm{PHMe}(\mathrm{Phes})$ and $\mathrm{PHMe}(\mathrm{Mes})^{11}$ were prepared as for $\mathrm{PHMe}(\mathrm{Is})^{9}$ and details will be reported separately. ${ }^{12}$ The synthesis of PHMe(Men) (Men $=\left((-)\right.$-menthyl) will also be reported separately. ${ }^{12}$

\section{Preparation of the Catalyst Precursor Pt((R,R)-Me-Duphos)(Ph)(PMeIs) (3) PHMe(Is) (141} $\mathrm{mg}, 0.56 \mathrm{mmol})$ was added with a microsyringe to a stirring slurry of $\mathrm{Pt}((\mathrm{R}, \mathrm{R})-\mathrm{Me}-\mathrm{Duphos})(\mathrm{Ph})(\mathrm{Cl})(346$ $\mathrm{mg}, 0.56 \mathrm{mmol})$ in toluene $(10 \mathrm{~mL}) . \mathrm{NaOSiMe}_{3}(63.3 \mathrm{mg}, 0.56 \mathrm{mmol})$ in toluene $(10 \mathrm{~mL})$ was added to the reaction mixture. As soon as $\mathrm{Pt}((\mathrm{R}, \mathrm{R})-\mathrm{Me}-\mathrm{Duphos})(\mathrm{Ph})(\mathrm{Cl})$ reacted, the mixture turned yellow; it was stirred for $\sim 3 \mathrm{~h}$. The slurry was filtered through Celite and the yellow filtrate was concentrated under 
vacuum. Petroleum ether was added to the yellow residue, yielding yellow crystals, which were washed further with petroleum ether, and dried under vacuum, yielding $415.5 \mathrm{mg}(89 \%)$ of yellow crystals suitable for X-ray crystallography.

Anal calcd for $\mathrm{C}_{40} \mathrm{H}_{59} \mathrm{P}_{3} \mathrm{Pt}$ : C, 58.03; H, 7.18. Found: C, 56.29; H, 7.41. Elemental analyses for carbon were consistently low, perhaps due to decomposition of the air-sensitive complex: Anal calcd for $\mathrm{C}_{40} \mathrm{H}_{59} \mathrm{P}_{3} \mathrm{PtO}: \mathrm{C}, 56.93 ; \mathrm{H}, 7.05$. We previously observed that the analogous $\mathrm{Pt}($ Duphos) phosphido complex Pt((R,R)-Me-Duphos)(H)(PPhIs) also failed to give satisfactory analyses. ${ }^{13}$ Since we could not obtain good analyses on this or the other Pt-phosphido complexes, we protonated them with $\mathrm{HBF}_{4}$ and isolated the resulting secondary phosphine complexes in analytically pure form after recrystallization (see below). ${ }^{14}$

HRMS m/z calcd. for $\mathrm{C}_{40} \mathrm{H}_{60} \mathrm{P}_{3} \mathrm{Pt}\left(\mathrm{MH}^{+}\right): \mathrm{m} / \mathrm{z}$ 828.3569. Found, 828.3571. ${ }^{1} \mathrm{H}$ NMR $\left(\mathrm{C}_{6} \mathrm{D}_{6}\right): \delta 8.07(\mathrm{t}$, $\mathrm{J}=6, \mathrm{~J}_{\mathrm{Pt}-\mathrm{H}}=51,1 \mathrm{H}, \mathrm{Ph}$ ortho $), 7.68\left(\mathrm{t}, \mathrm{J}=7, \mathrm{~J}_{\mathrm{Pt}-\mathrm{H}}=51,1 \mathrm{H}, \mathrm{Ph}\right.$ ortho $), 7.37(\mathrm{t}, \mathrm{J}=7,1 \mathrm{H}, \operatorname{Ar}), 7.29(\mathrm{t}, \mathrm{J}=7$, 1H, Ar), 7.21-7.18 (t, J = 6, 1H, Ar), 7.16 (2H, Is), 7.13-7.11 (m, 1H, Ar), 7.04 (t, J = 7, 1H, Ar), 6.97-6.90 (m, 2H, Ar), 5.16 (broad, 2H, CH, Is), 3.01-2.94 (m, 1H, CH), 2.89-2.81 (m, 1H, CH), 2.36-2.28 (m, 1H, $\mathrm{CH}), 2.17-2.08(\mathrm{~m}, 1 \mathrm{H}, \mathrm{CH}), 1.81-1.67(\mathrm{~m}, 3 \mathrm{H}), 1.62(\mathrm{dd}, \mathrm{J}=17,6,6 \mathrm{H}, \mathrm{Me}), 1.51(\mathrm{~d}, \mathrm{~J}=7,6 \mathrm{H}, \mathrm{Me})$, 1.48-1.43 (m, 3H, P-Me), 1.40 (dd, J = 18, 7, 6H, Me), 1.28 (d, J = 8, 3H, Me), 1.27 (d, J = 7, 3H, Me), $0.99(\mathrm{qd}, \mathrm{J}=13,5,1 \mathrm{H}), 0.90-0.80(\mathrm{~m}, 1 \mathrm{H}), 0.64\left(\mathrm{dd}, \mathrm{J}=14,7, \mathrm{~J}_{\mathrm{Pt}-\mathrm{H}}=53,3 \mathrm{H}, \mathrm{Me}\right), 0.58(\mathrm{dd}, \mathrm{J}=15,8,3 \mathrm{H}$, Me). ${ }^{13} \mathrm{C}\left\{{ }^{1} \mathrm{H}\right\} \operatorname{NMR}\left(\mathrm{C}_{6} \mathrm{D}_{6}\right): \delta 154.7$ (quat, $\mathrm{Ar}$ ), 147.7 (quat, $\mathrm{Ar}$ ), 147.2 (quat, $\mathrm{Ar}$ ), 143.9-143.5 (m, Ar), 139.9 (Ph ortho), 137.6 (broad, Ph ortho), 133.1 (dd, J = 86, 14, Duphos), 130.0 (d, J = 78, Duphos), 128.2-127.7 (m, Ar overlapping with $\mathrm{C}_{6} \mathrm{D}_{6}$ signals), 122.2 (Ph para), 120.5 (broad, 2C, Is meta), 44.1 (d, J = 30, $\mathrm{CH}$ Duphos), 41.9-41.4 (m, $\mathrm{CH}$ Duphos), $37.8\left(\mathrm{CH}_{2}\right), 36.3\left(\mathrm{CH}_{2}\right), 35.5$ (overlapping $\mathrm{CH}_{2}$ and $\mathrm{CH}$, Is), 34.7 (CH, Is), 34.3 (CH, Is), 32.8-32.1 (overlapping m and d, J = 42, 2CH Duphos), 27.2 (broad, $\mathrm{CH}_{3}$, Is), $24.5\left(\mathrm{CH}_{3}\right.$, Is), $22.6\left(\mathrm{CH}_{3}\right.$, Is), 18.1 (dd, $\mathrm{J}=20,9, \mathrm{CH}_{3}$, Duphos), 15.6 (d, J = 9, $\mathrm{CH}_{3}$, Duphos), 14.8 (d, $\mathrm{J}=3, \mathrm{CH}_{3}$, Duphos), 14.5 (d, J = 2, $\mathrm{CH}_{3}$, Duphos), 12.5-12.0 (m, P-CH $\left.\mathrm{CH}_{3}\right) \cdot{ }^{31} \mathrm{P}\left\{{ }^{1} \mathrm{H}\right\} \mathrm{NMR}\left(\mathrm{C}_{6} \mathrm{D}_{6}, 21{ }^{\circ} \mathrm{C}\right): \delta$ $58.3\left(\right.$ broad, $\left.\mathrm{J}_{\mathrm{Pt}-\mathrm{P}}=1869\right), 57.6\left(\mathrm{dd}, \mathrm{J}=133,8, \mathrm{~J}_{\mathrm{Pt}-\mathrm{P}}=1621\right),-51.8\left(\operatorname{broad} \mathrm{d}, \mathrm{J}=133, \mathrm{~J}_{\mathrm{Pt}-\mathrm{P}}=899\right)$.

${ }^{31} \mathrm{P}\left\{{ }^{1} \mathrm{H}\right\}$ NMR $\left(\mathrm{THF}_{-} \mathrm{d}_{8},-75^{\circ} \mathrm{C}\right): \delta 57.3\left(\mathrm{~J}_{\mathrm{Pt}-\mathrm{P}}=1868\right), 56.5\left(\mathrm{~d}, \mathrm{~J}=136, \mathrm{~J}_{\mathrm{Pt}-\mathrm{P}}=1653\right),-55.9(\mathrm{~d}, \mathrm{~J}=136$, $\mathrm{J}_{\mathrm{Pt}-\mathrm{P}}=889$ ). In addition, the phosphido resonances of three minor diastereomers were also observed: $\delta$ $-47.3\left(\mathrm{~d}, \mathrm{~J}=136, \mathrm{~J}_{\mathrm{Pt}-\mathrm{P}} \sim 940\right),-49.5(\mathrm{~d}, \mathrm{~J}=142),-51.6(\mathrm{~d}, \mathrm{~J}=134)$. The approximate ratio of the diastereomers was 120:2:1:1. In low-temperature ${ }^{31} \mathrm{P}$ NMR studies of analogous Pt(Duphos) phosphido 
complexes, to be reported separately, we have observed similar behavior; the "extra" diastereomers, besides the expected two, appear to be rotamers as a result of restricted rotation about the P-C(Is) and/or Pt-PMeIs bonds.

$[\operatorname{Pt}((\mathbf{R}, \mathbf{R})-M e-D u p h o s)(P h)(P H M e(I s))]\left[B_{4}\right] \quad(8)$ To a stirring solution of Pt((R,R)-MeDuphos $)(\mathrm{Ph})\left(\mathrm{PMe}(\mathrm{Is})(\mathbf{3}, 64 \mathrm{mg}, 0.08 \mathrm{mmol})\right.$ in $\mathrm{Et}_{2} \mathrm{O}(10 \mathrm{~mL})$ was added $\mathrm{HBF}_{4} \bullet \mathrm{Me}_{2} \mathrm{O}(12 \mathrm{mg}, 0.085$ mmol). A white precipitate formed immediately. After it settled, the solvent was removed with a pipette and the precipitate was washed with $\mathrm{Et}_{2} \mathrm{O}(3 \times 5 \mathrm{~mL})$. The precipitate was dried under vacuum, yielding 55 $\mathrm{mg}(75 \%)$ of white powder. The ${ }^{31} \mathrm{P}$ NMR spectrum is reported for a mixture of two diastereomers a and $\mathbf{b}$, whose ratio varied over time (ratio $\mathbf{b}: \mathbf{a}=1: 5$ after $1 \mathrm{~h}, 1: 14$ after $1 \mathrm{~d}$ ).

Anal. Calcd. for $\mathrm{C}_{40} \mathrm{H}_{60} \mathrm{P}_{3} \mathrm{PtBF}_{4}$ : C, 52.47; H, 6.60. Found: C, 52.09; H, 6.66. ${ }^{31} \mathrm{P}\left\{{ }^{1} \mathrm{H}\right\} \mathrm{NMR}\left(\mathrm{CD}_{2} \mathrm{Cl}_{2}\right)$ : diastereomer a: $\delta 63.1\left(\mathrm{dd}, \mathrm{J}=372,8, \mathrm{~J}_{\mathrm{Pt}-\mathrm{P}}=2623\right), 62.8\left(\mathrm{dd}, \mathrm{J}=18,8, \mathrm{~J}_{\mathrm{Pt}-\mathrm{P}}=1643\right),-62.6(\mathrm{dd}, \mathrm{J}=372$, $\left.18, \mathrm{~J}_{\mathrm{Pt}-\mathrm{P}}=2513\right)$; diastereomer b: $\delta 61.4\left(\mathrm{dd}, \mathrm{J}=376,6, \mathrm{~J}_{\mathrm{Pt}-\mathrm{P}}=2618\right), 67.6\left(\mathrm{~m}, \mathrm{~J}_{\mathrm{Pt}-\mathrm{P}}=1691\right),-55.2(\mathrm{dd}, \mathrm{J}=$ 376, 18, $\left.\mathrm{J}_{\mathrm{Pt}-\mathrm{P}}=2472\right)$. Selected ${ }^{1} \mathrm{H}$ NMR data $\left(\mathrm{CD}_{2} \mathrm{Cl}_{2}\right.$, all for the major diastereomer a unless indicated): $\delta 7.24$ (dm, J = 355, P-H, b), 7.21 (d, J = 4, 2H, Is), 6.79 (dm, J = 361, P-H), 1.45 (dd, J = 19, 7, 3H, CH

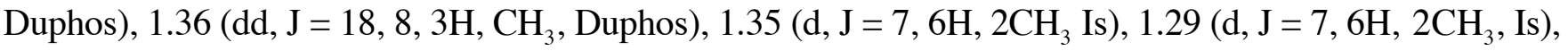
$1.26\left(\mathrm{~d}, \mathrm{~J}=7,6 \mathrm{H}, 2 \mathrm{CH}_{3}, \mathrm{Is}\right), 1.08\left(\mathrm{ddd}, \mathrm{J}=7,4,2, \mathrm{~J}_{\mathrm{Pt}-\mathrm{H}}=38, \mathrm{P}-\mathrm{CH}_{3}\right), 0.87$ (dd, J = 17, 8, 3H, $\mathrm{CH}_{3}$, Duphos), 0.74 (m, 1H, CH, Duphos), 0.69 (dd, J = 16, 7, 3H, $\mathrm{J}_{\mathrm{Pt}-\mathrm{H}}=131, \mathrm{CH}_{3}$, Duphos).

Preparation of the Catalyst Precursor Pt((R,R)-i-Pr-Duphos)(Ph)(Cl) A solution of (R,R)- $i-\operatorname{Pr}-$ Duphos $(293 \mathrm{mg}, 0.7 \mathrm{mmol})$ in $\mathrm{CH}_{2} \mathrm{Cl}_{2}(2 \mathrm{~mL})$ was added dropwise to a solution of $\mathrm{Pt}(\mathrm{COD})(\mathrm{Ph})(\mathrm{Cl})$ (291 mg, $0.7 \mathrm{mmol})$ in $\mathrm{CH}_{2} \mathrm{Cl}_{2}(3 \mathrm{~mL})$ to give a colorless solution. In the air, the solvent was removed under reduced pressure and the remaining crystals were washed with diethyl ether $(3 \times 2 \mathrm{~mL})$ and recrystallized from $\mathrm{CH}_{2} \mathrm{Cl}_{2}$ and diethyl ether at $-25{ }^{\circ} \mathrm{C}$ to yield $350 \mathrm{mg}(70 \%)$ of white $\mathrm{Pt}((\mathrm{R}, \mathrm{R})-i-\mathrm{Pr}-$ Duphos $)(\mathrm{Ph})(\mathrm{Cl})$ crystals. Anal. Calcd. for $\mathrm{C}_{32} \mathrm{H}_{49} \mathrm{ClP}_{2} \mathrm{Pt}$ : C, 52.92; H, 6.80. Found: C, 52.79; H, 6.41.

\footnotetext{
${ }^{31} \mathrm{P}\left\{{ }^{1} \mathrm{H}\right\} \operatorname{NMR}\left(\mathrm{C}_{6} \mathrm{D}_{6}\right): \delta 58.8\left(\mathrm{~d}, \mathrm{~J}=3, \mathrm{~J}_{\mathrm{Pt} \mathrm{P}}=1627\right), 47.2\left(\mathrm{~d}, \mathrm{~J}=3, \mathrm{~J}_{\mathrm{Pt}-\mathrm{P}}=3944\right) .{ }^{1} \mathrm{H} \mathrm{NMR}\left(\mathrm{C}_{6} \mathrm{D}_{6}\right): \delta$ $7.96\left(\mathrm{t}, \mathrm{J}=7, \mathrm{~J}_{\mathrm{Pt}-\mathrm{H}}=36,2 \mathrm{H}\right), 7.36-7.32(\mathrm{~m}, 3 \mathrm{H}), 7.20-7.16(\mathrm{~m}, 1 \mathrm{H}), 7.10(\mathrm{t}, \mathrm{J}=8,1 \mathrm{H}), 7.07-7.00(\mathrm{~m}, 2 \mathrm{H})$, 3.38-3.21 (m, 1H), 3.08-3.00 (m, 1H), 2.85-2.76 (m, 1H), 2.55-2.45 (m, 1H), 2.29-2.21 (m, 1H), 2.13-2.03 (m, 2H), 2.02-1.92 (m, 2H), 1.75-1.36 (m, 6H), 1.19 (d, J = 7, 3H, Me), 1.15 (d, J = 7, 3H, Me), 1.12-1.03 (m, 1H), 0.99 (d, J = 7, 3H, Me), $0.91(\mathrm{~d}, \mathrm{~J}=7,3 \mathrm{H}, \mathrm{Me}), 0.80(\mathrm{~d}, \mathrm{~J}=7,3 \mathrm{H}, \mathrm{Me}), 0.71(\mathrm{~d}, \mathrm{~J}=7,3 \mathrm{H}, \mathrm{Me})$, $0.64(\mathrm{~d}, \mathrm{~J}=7,3 \mathrm{H}, \mathrm{Me}), 0.56(\mathrm{~d}, \mathrm{~J}=7,3 \mathrm{H}, \mathrm{Me}) .{ }^{13} \mathrm{C}\left\{{ }^{1} \mathrm{H}\right\} \mathrm{NMR}\left(\mathrm{C}_{6} \mathrm{D}_{6}\right): \delta 161.5(\mathrm{dd}, \mathrm{J}=120,8$, quat, Pt-
} 
Ph), 145.3 (dd, $\mathrm{J}=45,38$, quat Ar), 144.3 (dd, J = 32, 24, quat Ar), $139.3(\mathrm{Ph}), 133.9$ (d, J = 13, Ar), 133.1 (dd, J = 15, 4, Ar), 131.4-131.2 (m, Ar), 131.1-130.9 (m, Ar), 128.6 (d, J = 7, Ph), $123.6(\mathrm{Ph}), 54.7$ (d, J = 23, CH), $53.8(\mathrm{~d}, \mathrm{~J}=38, \mathrm{CH}), 48.0(\mathrm{~d}, \mathrm{~J}=24, \mathrm{CH}), 46.6(\mathrm{~d}, \mathrm{~J}=34, \mathrm{CH}), 31.9,31.7,31.4,30.5(\mathrm{~d}, \mathrm{~J}=8)$, $30.4(\mathrm{~d}, \mathrm{~J}=7), 30.0(\mathrm{~d}, \mathrm{~J}=5), 29.4(\mathrm{~d}, \mathrm{~J}=2), 28.4(\mathrm{~m}), 26.3(\mathrm{~d}, \mathrm{~J}=7, \mathrm{Me}), 26.1(\mathrm{~d}, \mathrm{~J}=4, \mathrm{Me}), 25.5(\mathrm{~d}, \mathrm{~J}=$ 6, Me), $24.6(\mathrm{~d}, \mathrm{~J}=6, \mathrm{Me}), 22.2(\mathrm{~d}, \mathrm{~J}=11, \mathrm{Me}), 21.9(\mathrm{~d}, \mathrm{~J}=9, \mathrm{Me}), 21.5(\mathrm{~d}, \mathrm{~J}=6, \mathrm{Me}), 21.3(\mathrm{~d}, \mathrm{~J}=8$, $\mathrm{Me})$.

Preparation of the Catalyst Precursor Pt((R,R)-i-Pr-Duphos)(Ph)(PMeIs) PHMe(Is) (112.5 mg, $0.45 \mathrm{mmol})$ was added with a microsyringe to a stirring slurry of $\mathrm{Pt}((\mathrm{R}, \mathrm{R})-i$-Pr-Duphos $)(\mathrm{Ph})(\mathrm{Cl})(327 \mathrm{mg}$, $0.45 \mathrm{mmol})$ in THF $(20 \mathrm{~mL}) . \mathrm{NaOSiMe}_{3}(50.5 \mathrm{mg}, 0.45 \mathrm{mmol})$ in toluene $(10 \mathrm{~mL})$ was added to the reaction mixture. The mixture turned yellow immediately. The solvent was removed under vacuum, and toluene $(20 \mathrm{~mL})$ was added to the residue. The toluene slurry was filtered through Celite, and the yellow filtrate was concentrated under vacuum. Petroleum ether was added to the yellow residue. The yellow solution was stored at $-25^{\circ} \mathrm{C}$ for $24 \mathrm{~h}$, yielding yellow crystals suitable for X-ray crystallography, and a yellow solution. The yellow crystals were further washed with petroleum ether $(3 \times 5 \mathrm{~mL})$ and dried under vacuum, yielding $300 \mathrm{mg}(71 \%)$ of yellow crystals. Anal. Calcd. for $\mathrm{C}_{48} \mathrm{H}_{75} \mathrm{P}_{3} \mathrm{Pt}$ : C, 61.32; H, 8.04. Found: C, 59.14; H, 7.90. Satisfactory analyses for C could not be obtained, perhaps because of the airsensitivity of the complex (Anal. Calcd. for $\mathrm{C}_{48} \mathrm{H}_{75} \mathrm{P}$ PtO: C, 60.30; H, 7.91). Mass spectroscopy was also consistent with oxidation. HRMS (FAB) calcd for $\mathrm{C}_{48} \mathrm{H}_{76} \mathrm{OP}_{3} \mathrm{Pt}^{+}\left(\mathrm{M}(\mathrm{O}) \mathrm{H}^{+}\right): \mathrm{m} / \mathrm{z}$ 956.4771. Found: $\mathrm{m} / \mathrm{z}$ 956.4668.

${ }^{31} \mathrm{P}\left\{{ }^{1} \mathrm{H}\right\}$ NMR $\left(\mathrm{THF}-\mathrm{d}_{8}\right): \delta 54.3\left(\mathrm{~d}, \mathrm{~J}=131, \mathrm{~J}_{\mathrm{Pt}-\mathrm{P}}=1654\right), 50.8$ (broad, $\left.\mathrm{J}_{\mathrm{Pt}-\mathrm{P}}=1818\right),-60.0\left(\right.$ broad). ${ }^{1} \mathrm{H}$ NMR (THF-d ${ }_{8}$ ): $\delta$ 7.88-7.86 (m, 1H, Ar, Duphos), 7.83-7.80 (m, 1H, Ar, Duphos), 7.57 (broad, 1H, Ph ortho), 7.48-7.43 (m, 2H, Ar, Duphos), 7.39 (broad t, J = 7, 1H, $\mathrm{J}_{\mathrm{Pt}-\mathrm{H}}=49$, Ph ortho), 6.98 (broad t, J = 8, 1H, Ph meta), 6.94 (broad, 1H, Ph para), 6.90 (2H, Is meta), 6.72 (broad t, J = 8, 1H, Ph meta), 4.68 (broad, 2H, CH, Is), 2.83-2.71 (m, 2H, overlapping $\mathrm{CH}$ Duphos + $\mathrm{CH}$ Is), 2.70-2.62 (broad, 1H, $\mathrm{CH}$ Duphos), 2.45-2.33 (m, 2H, 2CH Duphos), 2.30-2.16 (broad m, 1H, CH Duphos), 1.99-1.75 (m, 5H, $\left.\mathrm{CH}+\mathrm{CH}_{2}\right), 1.75-1.68\left(\mathrm{~m}, 2 \mathrm{H}, \mathrm{CH}_{2}\right), 1.64-1.55\left(\mathrm{~m}, 2 \mathrm{H}, \mathrm{CH}_{2}\right), 1.49$ (qd, J = 13, 5, 2H, CH Duphos), 1.25$1.18\left(\mathrm{~m}, 18 \mathrm{H}, \mathrm{CH}_{3}\right), 1.05$ (broad, 3H, $\mathrm{CH}_{3}$ ), 0.96-0.82 (m, 9H, overlapping $\mathrm{CH}_{3}$ Duphos and P-Me), 0.68$0.62\left(\mathrm{~m}, 9 \mathrm{H}\right.$, overlapping $\left.\mathrm{CH}_{3}\right), 0.49$ (broad, $\left.3 \mathrm{H}, \mathrm{CH}_{3}\right), 0.38\left(\operatorname{broad}, 3 \mathrm{H}, \mathrm{CH}_{3}\right) \cdot{ }^{13} \mathrm{C}\left\{{ }^{1} \mathrm{H}\right\} \mathrm{NMR}\left(\mathrm{THF}^{-\mathrm{d}_{8}}\right): \delta$ 161.4 (m, Pt-C, quat Ph), 155.0 (broad, quat Is), 149.0-148.5 (m, quat Duphos), 147.8 (quat Is), 145.2- 
144.7 (m, quat Duphos), 144.2 (m, quat Is), 140.3 (broad, Ph ortho), 139.2 (Ph ortho), 135.5 (d, J = 15, Ar, Duphos), 134.3 (d, J = 12, Ar, Duphos), 131.3 (m, Ar, Duphos), 130.8 (m, Ar, Duphos), 128.2 (d, J = 6, Ph meta), 127.8 (m, Ph para), 122.2 (Ph meta), 121.1 (Is), 57.2 (d, J = 24, CH, Duphos), 55.9 (d, J = 25, CH, Duphos), 50.1 (broad m, CH, Duphos), 46.1 (d, J = 23, CH Duphos), 35.3 (CH, Is), 33.7 (d, J = 17, CH, Is), 32.5 (CH, Duphos), 31.6 (m, CH, Duphos), $31.1\left(\mathrm{~d}, \mathrm{~J}=6, \mathrm{CH}_{2}\right), 30.9-30.5$ (m, $\mathrm{CH}$, Duphos), 30.129.8 (m, CH, Duphos), 29.8 (d, J = 8, $\left.\mathrm{CH}_{2}\right), 29.2\left(\mathrm{CH}_{2}\right.$, Duphos), $27.9\left(\mathrm{CH}_{3}\right), 26.9\left(\mathrm{~d}, \mathrm{~J}=4, \mathrm{CH}_{3}\right), 26.5(\mathrm{~d}$, $\left.\mathrm{J}=2, \mathrm{CH}_{3}\right), 25.1\left(\mathrm{~d}, \mathrm{~J}=6, \mathrm{CH}_{3}\right), 24.6\left(\mathrm{~m}, \mathrm{CH}_{3}, \mathrm{Is}\right), 22.3\left(\mathrm{~d}, \mathrm{~J}=11, \mathrm{CH}_{3}\right), 22.2\left(\mathrm{~d}, \mathrm{~J}=11, \mathrm{CH}_{3}\right), 21.1(\mathrm{~d}, \mathrm{~J}$ $\left.=6, \mathrm{CH}_{3}\right), 20.0\left(\right.$ broad, $\left.\mathrm{CH}_{3}\right), 12.8\left(\right.$ broad $\left.\mathrm{m}, \mathrm{P}-\mathrm{CH}_{3}\right)$.

$\left[\mathbf{P t}((\mathbf{R}, \mathbf{R})-\boldsymbol{i}-\mathbf{P r}-\mathrm{Duphos})(\mathbf{P h})(\mathbf{P H M e}(\mathbf{I s})]\left[\mathbf{B F}_{4}\right]\right.$ A solution of $\mathrm{HBF}_{4} \bullet \mathrm{Me}_{2} \mathrm{O}(11.6 \mathrm{mg}, 0.086 \mathrm{mmol})$ in $10 \mathrm{~mL}$ of $\mathrm{Et}_{2} \mathrm{O}$ was added to a yellow solution of $\mathrm{Pt}((\mathrm{R}, \mathrm{R})-i$-Pr-Duphos)(Ph)(PMeIs) (74 mg, $0.08 \mathrm{mmol})$ in $10 \mathrm{~mL}$ of $\mathrm{Et}_{2} \mathrm{O}$. A white precipitate formed immediately. The solvent was removed with a pipet, and the precipitate was washed with $\mathrm{Et}_{2} \mathrm{O}(3$ portions of $5 \mathrm{~mL})$, then dried under vacuum, yielding $55 \mathrm{mg}(67 \%)$ of the product as a mixture of two diastereomers $\mathbf{a}$ and $\mathbf{b}$ in a ratio 1.3:1 (from both ${ }^{1} \mathrm{H}$ and ${ }^{31} \mathrm{P}\left\{{ }^{1} \mathrm{H}\right\}$ NMR integration). Recrystallization from THF/petroleum ether yielded crystals of diastereomer a, as shown by NMR spectroscopy in $\mathrm{CD}_{2} \mathrm{Cl}_{2}$. The solvent was removed from this sample under vacuum to give a solid which analyzed correctly for a $\mathrm{CD}_{2} \mathrm{Cl}_{2}$ solvate.

Anal. Calcd. for $\mathrm{C}_{48} \mathrm{H}_{76} \mathrm{P}_{3} \mathrm{PtBF}_{4} \cdot \mathrm{CD}_{2} \mathrm{Cl}_{2}$ : C, 52.79; H, 6.87. Found: C, 52.74; H, 7.16. From comparison of the NMR spectra of the 1.3:1 mixture and pure diastereomer a, assignments of most of the NMR signals could be made. ${ }^{31} \mathrm{P}\left\{{ }^{1} \mathrm{H}\right\} \mathrm{NMR}\left(\mathrm{CD}_{2} \mathrm{Cl}_{2}\right)$ : diastereomer $\mathbf{a}: \delta 58.4\left(\mathrm{dd}, \mathrm{J}=372,6, \mathrm{~J}_{\mathrm{Pt}-\mathrm{P}}=\right.$ 2681), $57.3\left(\mathrm{dd}, \mathrm{J}=17,6, \mathrm{~J}_{\mathrm{Pt}-\mathrm{P}}=1656\right),-66.1\left(\mathrm{dd}, \mathrm{J}=372,17, \mathrm{~J}_{\mathrm{Pt}-\mathrm{P}}=2510\right)$; diastereomer $\mathbf{b}: \delta 57.1(\mathrm{dd}, \mathrm{J}$ $\left.=372,5, \mathrm{~J}_{\mathrm{Pt}-\mathrm{P}}=2687\right), 53.7\left(\mathrm{dd}, \mathrm{J}=15,5, \mathrm{~J}_{\mathrm{Pt}-\mathrm{P}}=1631\right),-60.3\left(\mathrm{dd}, \mathrm{J}=377,15, \mathrm{~J}_{\mathrm{Pt}-\mathrm{P}}=2481\right)$.

${ }^{1} \mathrm{H}$ NMR (diastereomer a, $\mathrm{CD}_{2} \mathrm{Cl}_{2}$ ): $\delta$ 7.85-7.80 (m, 1H, Ar), 7.77-7.74 (m, 1H, Ar), 7.74-7.66 (m, 2H, Ar), 7.65-7.50 (t, J = 6, J $\mathrm{Pt}-\mathrm{H}=41,1 \mathrm{H}, \operatorname{Ar}), 7.31-7.24(\mathrm{~m}, 3 \mathrm{H}, \mathrm{Ar}), 7.18(\mathrm{~d}, \mathrm{~J}=3,2 \mathrm{H}, \mathrm{Ar}), 7.12-7.02(\mathrm{~m}, 1 \mathrm{H}$, Ar), $6.76(\mathrm{dm}, \mathrm{J}=358,1 \mathrm{H}, \mathrm{PH}), 3.52-3.50(\mathrm{~m}, 2 \mathrm{H}, i$-Pr CH), 2.94-2.89 (m, 1H), 2.74-2.51 (m, 5H), 2.09$1.83(\mathrm{~m}, 5 \mathrm{H}), 1.71-1.66(\mathrm{~m}, 1 \mathrm{H}), 1.60-1.44(\mathrm{~m}, 5 \mathrm{H}), 1.33-1.28$ (overlapping $\mathrm{m}, 15 \mathrm{H}), 1.23$ (overlapping d, $\mathrm{J}=7,6 \mathrm{H}), 1.12-1.07(\mathrm{~m}, 3 \mathrm{H}, \mathrm{P}-\mathrm{Me}), 1.03(\mathrm{~d}, \mathrm{~J}=6,3 \mathrm{H}), 0.76(\mathrm{~d}, \mathrm{~J}=6,3 \mathrm{H}), 0.64(\mathrm{~d}, \mathrm{~J}=6,3 \mathrm{H}), 0.56(\mathrm{~d}, \mathrm{~J}$ $=6,3 \mathrm{H}), 0.30(\mathrm{~d}, \mathrm{~J}=6,3 \mathrm{H}), 0.18(\mathrm{~d}, \mathrm{~J}=6,3 \mathrm{H}) .{ }^{1} \mathrm{H} \mathrm{NMR}$ (selected signals for diastereomer $\mathbf{b}, \mathrm{CD}_{2} \mathrm{Cl}_{2}$; in some cases, overlap with signals from a precluded assignment): $\delta$ 7.93-7.91 (m, 1H, Ar), 7.82-7.72 (m, overlapping signals from major diastereomer, 2H, Ar), 7.01 (broad, 2H, Ar), 6.86-6.84 (m, 2H, Ar), 6.74- 
$6.71(\mathrm{~m}, 1 \mathrm{H}, \mathrm{Ar}), 6.44(\mathrm{dm}, \mathrm{J}=372,1 \mathrm{H}, \mathrm{PH}), 1.36-1.28$ (m, overlapping signals from major diastereomer, 9H), 1.23 (d, J = 7, 6H), 1.14-1.08 (m, overlapping signals from major diastereomer, 9H), 0.99 (d, J = 7, $3 \mathrm{H}), 0.89(\mathrm{~d}, \mathrm{~J}=6,3 \mathrm{H}), 0.87(\mathrm{~d}, \mathrm{~J}=6,3 \mathrm{H}), 0.78(\mathrm{~d}, \mathrm{~J}=7,3 \mathrm{H}), 0.71(\mathrm{~d}, \mathrm{~J}=6,3 \mathrm{H}), 0.70(\mathrm{~d}, \mathrm{~J}=6,3 \mathrm{H})$, $0.58(\mathrm{~d}, \mathrm{~J}=6,3 \mathrm{H})$.

Preparation of the Catalyst Precursor Pt((R,R)-Me-Duphos)(I)(PMeIs) PHMe(Is) (91 mg, 0.36 mmol) was added with a microsyringe to a stirring slurry of $\mathrm{Pt}((\mathrm{R}, \mathrm{R})-\mathrm{Me}-\mathrm{Duphos}) \mathrm{I}_{2}$ (275 $\left.\mathrm{mg}, 0.36 \mathrm{mmol}\right)$ in toluene $(10 \mathrm{~mL}) . \mathrm{NaOSiMe}_{3}(40.8 \mathrm{mg}, 0.36 \mathrm{mmol})$ in toluene $(10 \mathrm{~mL})$ was added to the reaction mixture. The mixture turned yellow, and the solution became homogeneous after $10 \mathrm{~min}$. The slurry was filtered through Celite, and the yellow filtrate was concentrated under vacuum. Petroleum ether was added to the yellow residue. The solution was stored at $-25^{\circ} \mathrm{C}$ for $24 \mathrm{~h}$, yielding yellow crystals suitable for $\mathrm{X}$ ray crystallography and a yellow solution. The yellow crystals were further washed with petroleum ether (3 x $5 \mathrm{~mL}$ ) and dried under vacuum, yielding $250 \mathrm{mg}(78 \%)$ of yellow crystals.

HRMS m/z calcd. for $\mathrm{C}_{34} \mathrm{H}_{55} \mathrm{IP}_{3} \mathrm{Pt}\left(\mathrm{MH}^{+}\right)$877.2188. Found, 877.1935. Anal. calcd. for $\mathrm{C}_{34} \mathrm{H}_{54} \mathrm{IP}_{3} \mathrm{Pt}$ : C, 46.53; H, 6.20. Found: C, 35.09; H, 5.19. The poor analytical results presumably stem from decomposition of the air-sensitive sample. ${ }^{31} \mathrm{P}\left\{{ }^{1} \mathrm{H}\right\} \mathrm{NMR}\left(21{ }^{\circ} \mathrm{C}\right.$, toluene- $\left.\mathrm{d}_{8}\right): \delta 64.5\left(\right.$ broad d, $\left.\mathrm{J}=117, \mathrm{~J}_{\mathrm{Pt}-\mathrm{P}}=1559\right), 54.4$ (broad, $\left.\mathrm{J}_{\mathrm{Pt}-\mathrm{P}}=3943\right),-68.3\left(\right.$ broad, $\left.\mathrm{J}_{\mathrm{Pt}-\mathrm{P}}=842\right) .{ }^{31} \mathrm{P}\left\{{ }^{1} \mathrm{H}\right\} \mathrm{NMR}\left(-40{ }^{\circ} \mathrm{C}\right.$, toluene- $\left.\mathrm{d}_{8}\right): \delta 65.8\left(\mathrm{~d}, \mathrm{~J}=113, \mathrm{~J}_{\mathrm{Pt}-\mathrm{P}}\right.$ $=1633, \mathbf{b}), 64.0\left(\mathrm{dd}, \mathrm{J}=113,17, \mathrm{~J}_{\mathrm{Pt}-\mathrm{P}}=1575, \mathbf{a}\right), 65.0\left(\mathrm{broad}, \mathrm{J}_{\mathrm{Pt}-\mathrm{P}}=3876, \mathbf{b}\right), 54.1\left(\mathrm{dd}, \mathrm{J}=21,17, \mathrm{~J}_{\mathrm{Pt}-\mathrm{P}}=\right.$ $3954, \mathbf{a}),-42.5\left(\mathrm{~d}, \mathrm{~J}=110, \mathrm{~J}_{\mathrm{Pt}-\mathrm{P}}=935, \mathbf{b}\right),-69.6\left(\mathrm{dd}, \mathrm{J}=113,21, \mathrm{~J}_{\mathrm{Pt}-\mathrm{P}}=820, \mathbf{a}\right) .{ }^{1} \mathrm{H} \mathrm{NMR}\left(21^{\circ} \mathrm{C}\right.$, toluene$\left.\mathrm{d}_{8}\right): \delta$ 7.25-7.19 (m, 1H, Ar), 7.18-7.12 (m, 3H, Ar), 7.08-7.04 (m, 2H, Ar), 5.21 (broad, 2H, CH), 3.973.87 (m, 1H, CH), 2.87-2.80 (m, 1H, CH), 2.77-2.60 (broad, 3H), 2.58-2.49 (m, 2H), 2.36 (broad, 1H), 2.22-1.80 (m, 5H), $1.60\left(\mathrm{dd}, \mathrm{J}=18,7,3 \mathrm{H}, \mathrm{CH}_{3}\right), 1.48\left(\mathrm{~d}, \mathrm{~J}=8,3 \mathrm{H}, \mathrm{CH}_{3}\right), 1.45\left(\mathrm{~d}, \mathrm{~J}=7,6 \mathrm{H}, 2 \mathrm{CH}_{3}\right), 1.38$ $\left(\mathrm{d}, \mathrm{J}=7,6 \mathrm{H}, 2 \mathrm{CH}_{3}\right), 1.29\left(\mathrm{~d}, \mathrm{~J}=7,6 \mathrm{H}, 2 \mathrm{CH}_{3}\right), 0.86\left(\mathrm{~d}, \mathrm{~J}=7,3 \mathrm{H}, \mathrm{CH}_{3}\right), 0.54\left(\mathrm{dd}, \mathrm{J}=15,7,3 \mathrm{H}, \mathrm{CH}_{3}\right)$, $0.51\left(\mathrm{dd}, \mathrm{J}=14,7,3 \mathrm{H}, \mathrm{CH}_{3}\right)$.

$[\operatorname{Pt}((\mathbf{R}, \mathbf{R})-\mathbf{M e}-D u p h o s)(\mathbf{I})(\mathbf{P H M e}(\mathbf{I s}))]\left[\mathbf{B F}_{4}\right] . \quad$ To a stirring solution of $\operatorname{Pt}((\mathrm{R}, \mathrm{R})-\mathrm{Me}-$ Duphos)(I)(PMeIs) $(88 \mathrm{mg}, 0.1 \mathrm{mmol})$ in $\mathrm{Et}_{2} \mathrm{O}(10 \mathrm{~mL})$ was added $\mathrm{HBF}_{4} \bullet \mathrm{Me}_{2} \mathrm{O}(16 \mathrm{mg}, 12.5 \mu \mathrm{L}, 0.12$ mmol). An off-white precipitate formed immediately. After it settled, the solvent was removed with a pipette and the precipitate was washed with $\mathrm{Et}_{2} \mathrm{O}(3 \times 5 \mathrm{~mL})$. The precipitate was dried under vacuum, yielding 85 $\mathrm{mg}(88 \%)$ of off-white powder, which was recrystallized from $\mathrm{CH}_{2} \mathrm{Cl}_{2} / \mathrm{Et}_{2} \mathrm{O}$ for elemental analyses. Note: this and the related cationic secondary phosphine complexes tended to co-crystallize with these solvents, 
which were readily lost on standing. In this case, a trace of $\mathrm{CH}_{2} \mathrm{Cl}_{2}$, quantified by integration, was observed by ${ }^{1} \mathrm{H}$ NMR spectroscopy in the analytical sample. Anal. Calcd. for $\mathrm{C}_{34} \mathrm{H}_{55} \mathrm{IP}_{3} \mathrm{PtBF}_{4}: \mathrm{C}, 42.30 ; \mathrm{H}, 5.74$. Anal. Calcd. for $\mathrm{BC}_{34} \mathrm{~F}_{4} \mathrm{H}_{55} \mathrm{IP}_{3} \mathrm{Pt} \bullet 0.05 \mathrm{CH}_{2} \mathrm{Cl}_{2}$ : C, 42.17; H, 5.73. Found: C, 41.77; H, 5.80. HRMS m/z calcd for $\left(\mathrm{C}_{34} \mathrm{H}_{55} \mathrm{IP}_{3} \mathrm{Pt}\right)^{+}\left(\mathrm{M}^{+}\right)$: 877.2188. Found: 877.2193.

The NMR spectra are reported for a mixture of two diastereomers $\mathbf{a}$ and $\mathbf{b}$ (ratio $\mathbf{a}: \mathbf{b}=3: 1$ based on integration of the ${ }^{1} \mathrm{H}$ NMR spectrum). ${ }^{31} \mathrm{P}\left\{{ }^{1} \mathrm{H}\right\}$ NMR $\left(\mathrm{CD}_{2} \mathrm{Cl}_{2}\right)$ : diastereomer a: $\delta 74.8\left(\mathrm{~d}, \mathrm{~J}=374, \mathrm{~J}_{\mathrm{Pt}-\mathrm{P}}\right.$ $=2321), 65.0\left(\mathrm{~d}, \mathrm{~J}=18, \mathrm{~J}_{\mathrm{Pt}-\mathrm{P}}=3102\right),-72.0\left(\mathrm{dd}, \mathrm{J}=374,18, \mathrm{~J}_{\mathrm{Pt}-\mathrm{P}}=2213\right)$; diastereomer $\mathbf{b}: \delta 73.4(\mathrm{~d}, \mathrm{~J}=$ $\left.383, \mathrm{~J}_{\mathrm{Pt}-\mathrm{P}}=2289\right), 72.0\left(\mathrm{~d}, \mathrm{~J}=15, \mathrm{~J}_{\mathrm{Pt}-\mathrm{P}}=3175\right),-65.8\left(\mathrm{dd}, \mathrm{J}=383,15, \mathrm{~J}_{\mathrm{Pt}-\mathrm{P}}=2164\right) .{ }^{1} \mathrm{H} \mathrm{NMR}\left(\mathrm{CD}_{2} \mathrm{Cl}_{2}\right): \delta$ 7.92-7.76 (m, 3H), $7.73(\mathrm{tm}, \mathrm{J}=7,1 \mathrm{H}), 7.22(\mathrm{~d}, \mathrm{~J}=4,2 \mathrm{H}, \mathrm{Is}, \mathbf{a}), 7.16(\mathrm{~d}, \mathrm{~J}=4,2 \mathrm{H}, \mathrm{Is}, \mathbf{b}), 6.67(\mathrm{dm}, \mathrm{J}=$ 384, P-H, b), 6.43 (dm, J = 343, P-H, a), 4.06-3.93 (m, 1H, a), 3.88-3.78 (m, 1H), 3.62-3.54 (m, 1H, b), 3.12-2.79 (m, 2H), 2.63-2.23 (m, 5H), 2.23-2.08 (m, 1H, a), 2.08-1.78 (m, 2H), 1.78-1.66 (m, 1H, b), 1.54 $(\mathrm{d}, \mathrm{J}=7,3 \mathrm{H}, \mathbf{a}), 1.53(\mathrm{dd}, \mathrm{J}=20,7,3 \mathrm{H}$, a, overlapping $3 \mathrm{H}, \mathbf{b}), 1.43-1.33(\mathrm{~m}, 4 \mathrm{H}), 1.33-1.24(\mathrm{~m}, 18 \mathrm{H})$, $1.12(\mathrm{dd}, \mathrm{J}=7,3,3 \mathrm{H}, \mathbf{b}), 1.09$ (d, J = 7, 3H, b), 0.90-0.82 (m, 3H), 0.69 (dd, J = 17, 7, 3H, a).

Preparation of the Catalyst Precursor Pt((R,R)-Me-Duphos)(PMeIs) ${ }_{2}$ PHMe(Is) (120 mg, 0.48 mmol) was added with a microsyringe to a stirring slurry of $\operatorname{Pt}((\mathrm{R}, \mathrm{R})-\mathrm{Me}-\mathrm{Duphos}) \mathrm{Cl}_{2}(137 \mathrm{mg}, 0.24$ $\mathrm{mmol})$ in toluene $(10 \mathrm{~mL}) . \mathrm{NaOSiMe}_{3}(53.8 \mathrm{mg}, 0.48 \mathrm{mmol})$ in toluene $(10 \mathrm{~mL})$ was added to the reaction mixture. The mixture turned orange, and the solution became homogeneous after 30 min. The slurry was filtered through Celite, and the orange filtrate was concentrated under vacuum. Petroleum ether was added to the yellow residue. The solution was stored at $-25{ }^{\circ} \mathrm{C}$ for $24 \mathrm{~h}$, yielding yellow crystals suitable for Xray crystallography and a yellow solution. The yellow crystals were further washed with petroleum ether (3 x $5 \mathrm{~mL}$ ) and dried under vacuum, yielding $195 \mathrm{mg}(81 \%)$ of yellow crystals. Satisfactory elemental analyses could not be obtained for this complex, perhaps because of its air sensitivity. Anal. Calcd. for $\mathrm{C}_{50} \mathrm{H}_{80} \mathrm{P}_{4} \mathrm{Pt}$ : C, 60.04; H, 8.06. Found: C, 58.32; H, 8.11. These results are consistent with oxidation at both phosphorus centers: Anal. Calcd. for $\mathrm{C}_{50} \mathrm{H}_{80} \mathrm{O}_{2} \mathrm{P}_{4} \mathrm{Pt}$ : C, 58.18; H, 7.81. Mass spectroscopy was also consistent with oxidation: HRMS m/z calcd for $\mathrm{C}_{50} \mathrm{H}_{81} \mathrm{P}_{4} \mathrm{PtO}_{2}\left(\mathrm{MO}_{2} \mathrm{H}\right)^{+}$1032.4849. Found: $\mathrm{m} / \mathrm{z}$ 1032.4847.

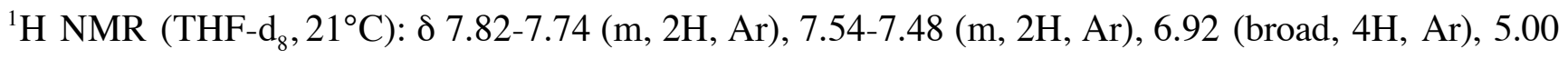
(broad, 4H, CH), 2.87-2.62 (m, 4H), 2.65-2.35 (broad, 2H), 2.28-2.10 (m, 2H), 2.10-1.70 (m, 6H), 1.62$1.54(\mathrm{~m}, 12 \mathrm{H}, \mathrm{Me}), 1.26-1.13$ (overlapping $\left.\mathrm{m}, 36 \mathrm{H}, \mathrm{CH}_{3}\right), 0.55\left(\mathrm{dd}, \mathrm{J}=25,12,6 \mathrm{H}, \mathrm{CH}_{3}\right) .{ }^{31} \mathrm{P}\left\{{ }^{1} \mathrm{H}\right\} \mathrm{NMR}$ 
$\left(\mathrm{C}_{6} \mathrm{D}_{6}, 21^{\circ} \mathrm{C}\right): \delta 57.1$ (broad), -56.9 (broad). ${ }^{31} \mathrm{P}\left\{{ }^{1} \mathrm{H}\right\} \mathrm{NMR}\left(\mathrm{THF}-\mathrm{d}_{8},-50^{\circ} \mathrm{C}\right): \delta 66.2\left(\mathrm{~d}, \mathrm{~J}=84, \mathrm{~J}_{\mathrm{Pt}-\mathrm{P}}=\right.$ $1677, \mathbf{a}), 60.6(\mathrm{~d}, \mathrm{~J}=99, \mathbf{c}), 57.8(\mathrm{~d}, \mathrm{~J}=115, \mathbf{d}), 52.1\left(\mathrm{~d}, \mathrm{~J}=110, \mathrm{~J}_{\mathrm{Pt} P}=1854, \mathbf{b}\right),-48.3\left(\mathrm{~d}, \mathrm{~J}=110, \mathrm{~J}_{\mathrm{Pt} P}=\right.$ $1001, \mathbf{b}),-62.9\left(\mathrm{dd}, \mathrm{J}=84,11, \mathrm{~J}_{\mathrm{Pt} \mathrm{P}}=887, \mathbf{a}\right),-64.5(\mathrm{~d}, \mathrm{~J}=99, \mathbf{c})$.

$\left[\operatorname{Pt}((\mathbf{R}, \mathbf{R})-M e-D u p h o s)(\operatorname{PHMe}(\mathbf{I s}))_{2}\right]\left[\mathbf{B F}_{4}\right]_{2} . \quad$ To a stirring solution of $\operatorname{Pt}((\mathrm{R}, \mathrm{R})-\mathrm{Me}-$ Duphos)(PMeIs) $)_{2}(100 \mathrm{mg}, 0.1 \mathrm{mmol})$ in $\mathrm{Et}_{2} \mathrm{O}(10 \mathrm{~mL})$ was added $\mathrm{HBF}_{4} \bullet \mathrm{Me}_{2} \mathrm{O}(32 \mathrm{mg}, 25 \mu \mathrm{L}, 0.24$ mmol). A white precipitate formed immediately. After it settled, the solvent was removed with a pipette and the precipitate was washed with $\mathrm{Et}_{2} \mathrm{O}(3 \times 5 \mathrm{~mL})$. The precipitate was dried under vacuum, yielding $115 \mathrm{mg}$ (98\%) of white powder. The ${ }^{31} \mathrm{P}$ NMR spectrum is reported for a mixture of at least 8 diastereomers. Recrystallization from $\mathrm{CH}_{2} \mathrm{Cl}_{2} / \mathrm{Et}_{2} \mathrm{O}$ yielded white crystals of a methylene chloride solvate that consisted of a mixture of only four diastereomers (as observed by ${ }^{1} \mathrm{H}$ NMR spectroscopy). Anal. Calcd. for $\mathrm{C}_{50} \mathrm{H}_{82} \mathrm{P}_{4} \mathrm{PtB}_{2} \mathrm{~F}_{8}: \mathrm{C}, 51.08 ; \mathrm{H}, 7.03$. Anal. Calcd. for $\mathrm{C}_{50} \mathrm{H}_{82} \mathrm{P}_{4} \mathrm{PtB}_{2} \mathrm{~F}_{8} \bullet \mathrm{CH}_{2} \mathrm{Cl}_{2}: \mathrm{C}, 48.59 ; \mathrm{H}, 6.72$. Found: $\mathrm{C}, 48.60 ; \mathrm{H}, 6.97$. HRMS m/z calcd for $\mathrm{C}_{50} \mathrm{H}_{83} \mathrm{P}_{4} \mathrm{Pt}(\mathrm{MH})^{3+}$ : 1001.5072. Found: 1001.4654.

${ }^{31} \mathrm{P}\left\{{ }^{1} \mathrm{H}\right\}$ NMR $\left(\mathrm{CD}_{2} \mathrm{Cl}_{2}\right)$ : diastereomer a: $\delta 70.3\left(\mathrm{AA}^{\prime} \mathrm{XX}\right.$ ' pattern, $\left.\mathrm{J}_{\mathrm{Pt}-\mathrm{P}}=2190\right)$, -71.6 (AA'XX', $\mathrm{J}_{\mathrm{Pt}-\mathrm{P}}=$ 2200); diastereomer b: $\delta 78.9\left(\mathrm{dd}, \mathrm{J}=377,3, \mathrm{~J}_{\mathrm{Pt} \mathrm{P}}=2377\right),-60.4\left(\mathrm{dd}, \mathrm{J}=377,18, \mathrm{~J}_{\mathrm{Pt} \mathrm{P}}=2228\right)$; diastereomer c: $\delta 78.8\left(\mathrm{dd}, \mathrm{J}=380,3, \mathrm{~J}_{\mathrm{Pt} \mathrm{P}}=2364\right),-53.5\left(\mathrm{dd}, \mathrm{J}=380,17, \mathrm{~J}_{\mathrm{Pt} \mathrm{P}}=2228\right)$; diastereomer $\mathbf{d}: \delta$ $80.6\left(\mathrm{dd}, \mathrm{J}=340,11, \mathrm{~J}_{\mathrm{Pt}-\mathrm{P}}=1848\right),-67.4\left(\mathrm{dd}, \mathrm{J}=340,18, \mathrm{~J}_{\mathrm{Pt}-\mathrm{P}}=2472\right)$; diastereomer e: $\delta 81.8(\mathrm{dd}, \mathrm{J}=314$, 3), $-59.1(\mathrm{dd}, \mathrm{J}=314,20)$; other diastereomers: $\delta 78.2\left(\mathrm{dd}, \mathrm{J}=252,18, \mathrm{~J}_{\mathrm{Pt}-\mathrm{P}}=2277\right), 68.3(\mathrm{dd}, \mathrm{J}=271,5$, $\mathrm{J}_{\mathrm{Pt} \mathrm{P}}=2472$ ), -65.4 (dd, J = 339, 17), -68.4 (broad), -69.9 (broad), -71.6 (broad). ${ }^{31} \mathrm{P}\left\{{ }^{1} \mathrm{H}\right\} \mathrm{NMR}\left(\mathrm{CD}_{2} \mathrm{Cl}_{2}\right)$ after recrystallization: diastereomer a: $\delta 70.7$ (AA'XX' pattern, $\mathrm{J}_{\mathrm{AX}}=297, \mathrm{~J}_{\mathrm{AX}}=-23, \mathrm{~J}_{\mathrm{AA}}=31, \mathrm{~J}_{\mathrm{XX}}=0, \mathrm{~J}_{\mathrm{Pt}-}$ $\left.{ }_{\mathrm{P}}=2188\right),-71.6\left(\mathrm{AA}^{\prime} \mathrm{XX}^{\prime}\right.$ pattern, $\left.\mathrm{J}_{\mathrm{AX}}=297, \mathrm{~J}_{\mathrm{AX}}=-23, \mathrm{~J}_{\mathrm{AA}^{\prime}}=31, \mathrm{~J}_{\mathrm{XX}}=0, \mathrm{~J}_{\mathrm{Pt} \mathrm{P}}=2202\right)$; other signals: $\delta$ 77.9 (broad d, $\mathrm{J}=294$ ), 68.5 (apparent dd, $\mathrm{J}=296,23, \mathrm{~J}_{\mathrm{Pt}-\mathrm{P}}=2150$ ), -67.9 (broad), -69.4 (broad). Selected ${ }^{1} \mathrm{H}$ NMR $\left(\mathrm{CD}_{2} \mathrm{Cl}_{2}\right)$ signals: $7.20\left(\mathrm{dm}, \mathrm{J}_{\mathrm{P}-\mathrm{H}}=391\right), 7.14\left(\mathrm{dm}, \mathrm{J}_{\mathrm{P}-\mathrm{H}}=385\right), 6.72\left(\mathrm{dm}, \mathrm{J}_{\mathrm{P}-\mathrm{H}}=390\right)$, $6.46\left(\mathrm{dm}, \mathrm{J}_{\mathrm{P}-\mathrm{H}} \sim 390\right.$, lowest intensity of the four P-H signals).

Preparation of the Catalyst Precursor Pt(R-Tol-Binap)(Ph)(Cl) A solution of (R)-Tol-Binap (94 $\mathrm{mg}, 0.23 \mathrm{mmol})$ in $\mathrm{CH}_{2} \mathrm{Cl}_{2}(2 \mathrm{~mL})$ was added dropwise to a solution of $\mathrm{Pt}(\mathrm{COD})(\mathrm{Ph})(\mathrm{Cl})(153 \mathrm{mg}, 0.23$ $\mathrm{mmol})$ in $\mathrm{CH}_{2} \mathrm{Cl}_{2}(3 \mathrm{~mL})$ to give a pale-yellow solution. In the air, the solvent was removed under reduced pressure and the remaining crystals were washed with diethyl ether $(3 \times 2 \mathrm{~mL})$ and recrystallized from $\mathrm{CH}_{2} \mathrm{Cl}_{2}$ and diethyl ether at $-25{ }^{\circ} \mathrm{C}$ to yield $200 \mathrm{mg}(90 \%)$ of white crystals. This material consistently (four samples) gave elemental analyses low in carbon, consistent with co-crystallization with $\mathrm{CH}_{2} \mathrm{Cl}_{2}$. 
However, the solid appeared to lose $\mathrm{CH}_{2} \mathrm{Cl}_{2}$ on standing, which made quantitative analyses of the solvation

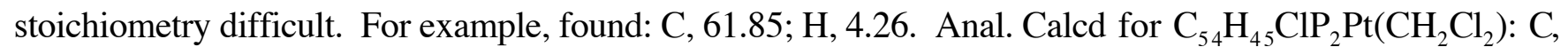
61.66; $\mathrm{H}, 4.42$. For another sample, analyses were consistent with the presence of 0.7 equiv of $\mathrm{CH}_{2} \mathrm{Cl}_{2}$. Found: C, 62.63; H, 4.29. Anal. Calcd for $\mathrm{C}_{54} \mathrm{H}_{45} \mathrm{ClP}_{2} \mathrm{Pt}\left(\mathrm{CH}_{2} \mathrm{Cl}_{2}\right)_{0.7}: \mathrm{C}, 62.82 ; \mathrm{H}, 4.47$. Integration of the NMR spectrum of this material in $\mathrm{CDCl}_{3}$ showed the presence of 0.6 equiv of $\mathrm{CH}_{2} \mathrm{Cl}_{2}$. When the crystalline material used for analysis was stored for one week, then redissolved again in $\mathrm{CDCl}_{3}$, the ${ }^{1} \mathrm{H}$ NMR spectrum showed that $\mathrm{CH}_{2} \mathrm{Cl}_{2}$ was no longer present. HRMS m/z calcd for $\mathrm{C}_{54} \mathrm{H}_{45} \mathrm{P}_{2} \mathrm{Pt}^{+}\left((\mathrm{M}-\mathrm{Cl})^{+}\right)$: 949.2623. Found: 949.2632.

${ }^{31} \mathrm{P}\left\{{ }^{1} \mathrm{H}\right\} \operatorname{NMR}\left(\mathrm{CDCl}_{3}\right): \delta 17.0\left(\mathrm{~d}, \mathrm{~J}=18, \mathrm{~J}_{\mathrm{Pt}-\mathrm{P}}=1630\right), 13.0\left(\mathrm{~d}, \mathrm{~J}=18, \mathrm{~J}_{\mathrm{Pt}-\mathrm{P}}=4358\right) .{ }^{1} \mathrm{H} \mathrm{NMR}$ $\left(\mathrm{CDCl}_{3}\right): \delta 7.83(\mathrm{dd}, \mathrm{J}=11,9,1 \mathrm{H}, \mathrm{Ar}), 7.74(\mathrm{dd}, \mathrm{J}=11,8,2 \mathrm{H}, \mathrm{Ar}), 7.63(\mathrm{dd}, \mathrm{J}=9,2,1 \mathrm{H}, \mathrm{Ar}), 7.55(\mathrm{~d}, \mathrm{~J}=$ 9, 2H, Ar), 7.43-7.27 (m, 10H, Ar), 7.16-7.11 (m, 3H, Ar), 7.05-7.01 (m, 2H, Ar), 6.83 (d, J = 9, 1H, Ar), $6.78(\mathrm{dd}, \mathrm{J}=8,3,2 \mathrm{H}, \mathrm{Ar}), 6.72(\mathrm{td}, \mathrm{J}=7,2,2 \mathrm{H}, \operatorname{Ar}), 6.62(\mathrm{t}, \mathrm{J}=9,2 \mathrm{H}, \operatorname{Ar}), 6.45$ (d, J = 8, 2H, Ar), 6.37 (broad, 3H, Ar), $2.42\left(3 \mathrm{H}, \mathrm{CH}_{3}\right), 2.20\left(3 \mathrm{H}, \mathrm{CH}_{3}\right), 1.98\left(3 \mathrm{H}, \mathrm{CH}_{3}\right), 1.96\left(3 \mathrm{H}, \mathrm{CH}_{3}\right) .{ }^{13} \mathrm{C}\left\{{ }^{1} \mathrm{H}\right\} \mathrm{NMR}$ $\left(\mathrm{CDCl}_{3}\right): \delta 140.2(\mathrm{~d}, \mathrm{~J}=2$, Ar), 139.8 (d, J = 3, Ar), $139.7(\mathrm{~d}, \mathrm{~J}=2$, Ar), 139.5 (d, J = 3, Ar), 139.1 (d, J = 4, Ar), 139.0 (d, J = 4, Ar), 137.8 (m, Ar), 135.7 (d, J = 11, Ar), 135.3 (d, J = 13, Ar), 134.9 (d, J = 10, Ar), 133.7 (d, J = 2, Ar), 133.6 (d, J = 2, Ar), 133.4 (d, J = 7, Ar), 133.2 (d, J = 9, Ar), 131.7 (Ar), 131.4 (Ar), 130.9 (Ar), 128.9 (d, J = 11, Ar), 128.4-128.1 (m, Ar), 128.0-127.6 (m, Ar), 127.2 (d, J = 8, Ar), 126.8 (d, J =11, Ar), $126.4(\mathrm{Ar}), 126.3(\mathrm{Ar}), 126.0(\mathrm{Ar}), 123.2(\mathrm{Ar}), 122.7(\mathrm{Ar}), 122.4(\mathrm{Ar}), 122.3(\mathrm{Ar}), 21.7\left(\mathrm{CH}_{3}\right)$, $21.32\left(\mathrm{CH}_{3}\right), 21.29\left(\mathrm{CH}_{3}\right), 21.24\left(\mathrm{CH}_{3}\right)$.

\section{General Procedure for Catalytic Reaction of Benzyl Halides with Secondary Phosphines To a} secondary phosphine $(0.1 \mathrm{mmol})$ in $0.2 \mathrm{~mL}$ of solvent (toluene or THF) was added $\mathrm{NaOSiMe}_{3}(11.2 \mathrm{mg}$, $0.1 \mathrm{mmol})$ suspended in $0.2 \mathrm{~mL}$ of solvent. The mixture was added to the catalyst precursor $(0.005 \mathrm{mmol}$, $5 \mathrm{~mol} \%)$ in $0.1 \mathrm{~mL}$ of solvent. The reaction mixture was transferred to an NMR tube. Benzyl halide $(0.1$ mmol) was added via microliter syringe, and the reaction mixture was monitored by ${ }^{31} \mathrm{P}$ NMR spectroscopy. After the reaction went to completion, the catalyst and the sodium halide were removed from the reaction mixture on a silica column (14 cm height, $1 \mathrm{~cm}$ diameter), using a 9:1 petroleum ether:THF mixture as eluent. The catalyst and the sodium halide did not elute. The solvent was removed under vacuum, and the tertiary phosphines were dissolved in $0.5 \mathrm{~mL}$ of $\mathrm{C}_{6} \mathrm{D}_{6}$ for spectroscopic characterization. 
Determination of ee The $\mathrm{C}_{6} \mathrm{D}_{6}$ solution of tertiary phosphines was added to (S)$\left\{\mathrm{Pd}\left[\mathrm{NMe}_{2} \mathrm{CH}(\mathrm{Me}) \mathrm{C}_{6} \mathrm{H}_{4}\right](\mu-\mathrm{Cl})\right\}_{2}(0.12 \mathrm{mmol}, 69.6 \mathrm{mg})$ and the ee was determined by integration of the ${ }^{31} \mathrm{P}$ NMR signals of the diastereomers (Table 1).

Table 1. Determination of the ee of the tertiary phosphines: ${ }^{31} \mathrm{P}$ NMR data of their diastereomeric adducts with a chiral Pd complex

\begin{tabular}{|l|l|}
\hline & $14.1,14.8^{\mathrm{b}}$ \\
\hline & \\
\hline
\end{tabular}




\begin{tabular}{|l|l|}
\hline & $37.7,39.0(\mathbf{b})$ \\
\hline
\end{tabular}

${ }^{a}$ The chemical shift of the major diastereomer is listed first. For diphosphines, chemical shifts for the rac isomer are listed first, followed by those for the meso isomer. ${ }^{b}$ In one case for the phosphine $\mathrm{PMe}(\mathrm{Is})\left(\mathrm{CH}_{2} \mathrm{Ph}\right)$, ee was determined using an analogous method with the (S)$\left\{\mathrm{Pd}\left[\mathrm{NMe}_{2} \mathrm{CH}(\mathrm{Me}) \mathrm{C}_{10} \mathrm{H}_{6}\right](\mathrm{Cl})\right\}_{2}$ complex. The resulting ${ }^{31} \mathrm{P}$ NMR shifts were $\delta 12.9$ and 15.3. ${ }^{\mathrm{c}}$ Peaks were not baseline resolved, so the error in the reported ee is larger than in the other examples.

\section{Stoichiometric reaction of $\operatorname{Pt}((\mathrm{R}, \mathrm{R})$-Me-Duphos)(Ph)(PMeIs) with benzyl bromide. Synthesis} of $\operatorname{Pt}((\mathbf{R}, \mathbf{R})-M e-D u p h o s)(P h)(B r)(6)$. A solution of $\operatorname{Pt}((\mathrm{R}, \mathrm{R})-\mathrm{Me}-\mathrm{Duphos})(\mathrm{Ph})(\mathrm{PMeIs})(\mathbf{3}, 124.2 \mathrm{mg}$, $0.15 \mathrm{mmol})$ in toluene $(5 \mathrm{~mL})$ was transferred into an NMR tube, which was fitted with a septum. The tube was cooled in a NaCl/ice bath at $-5{ }^{\circ} \mathrm{C}$. Benzyl bromide (26 $\mathrm{mg}, 18 \mu \mathrm{L}, 0.15 \mathrm{mmol}$ ) was added via a microliter syringe, and the reaction mixture was kept at $-15^{\circ} \mathrm{C}$ for $10 \mathrm{~h}$, when the reaction was completed, according to ${ }^{31} \mathrm{P}$ NMR. Pt(Me-Duphos $)(\mathrm{Ph})(\mathrm{Br})(\mathbf{6})$ and $\mathrm{PMeIs}\left(\mathrm{CH}_{2} \mathrm{Ph}\right)(5)$ were the only components of the mixture observed in toluene. The solvent was removed under vacuum and $5 \mathrm{~mL}$ of petroleum ether was added to the white solid. The solid was allowed to settle and the liquid was removed with a pipette. The white solid was further washed with 3 portions of $5 \mathrm{~mL}$ of petroleum ether, dried under vacuum, and redissolved in $\mathrm{CD}_{2} \mathrm{Cl}_{2}$. $\mathrm{Pt}(\mathrm{Me}-\mathrm{Duphos})(\mathrm{Ph})(\mathrm{Br})(41 \%)$ and $\mathrm{PMeIs}\left(\mathrm{CH}_{2} \mathrm{Ph}\right)(36 \%)$ were observed as the major components of the mixture, along with $23 \%$ of $\left[\mathrm{Pt}(\mathrm{Me}-\mathrm{Duphos})(\mathrm{Ph})\left(\mathrm{PMeIs}\left(\mathrm{CH}_{2} \mathrm{Ph}\right)\right][\mathrm{Br}]\right.$, which was independently synthesized as the $\mathrm{BF}_{4}$ salt (see below). The solvent was removed under vacuum and 5 mL of a 9:1 mixture of petroleum ether:THF was added to the residue. A white precipitate was formed. The precipitate was washed with 5 portions of $5 \mathrm{~mL}$ of the 9:1 mixture of petroleum ether:THF. The washes were collected and the tertiary phosphine was isolated by filtration on a silica column $(5 \mathrm{~cm}$ height, $0.6 \mathrm{~cm}$ 
diameter), using a 9:1 petroleum ether:THF mixture as eluent, followed by solvent removal under vacuum, yielding $38 \mathrm{mg}$ of colorless liquid ( $75 \%$ yield). The white precipitate (the Pt-bromide complex) was dried under vacuum and recrystallized from THF and petroleum ether at $-10{ }^{\circ} \mathrm{C}$, yielding $80 \mathrm{mg}(82 \%)$ of white crystals suitable for X-ray crystallography.

Anal. Calcd. for $\mathrm{BrC}_{24} \mathrm{H}_{33} \mathrm{P}$ Pt: C, 43.78; H, 5.05. Found: C, 43.85; H, 4.97. ${ }^{31} \mathrm{P}\left\{{ }^{1} \mathrm{H}\right\} \mathrm{NMR}\left(\mathrm{CD}_{2} \mathrm{Cl}_{2}\right)$ : $\delta 66.0\left(\mathrm{~d}, \mathrm{~J}=6, \mathrm{~J}_{\mathrm{Pt}-\mathrm{P}}=1647\right), 56.8\left(\mathrm{~d}, \mathrm{~J}=6, \mathrm{~J}_{\mathrm{Pt}-\mathrm{P}}=3960\right) .{ }^{1} \mathrm{H} \mathrm{NMR}\left(\mathrm{CD}_{2} \mathrm{Cl}_{2}\right): \delta 7.78-7.73(\mathrm{~m}, 1 \mathrm{H}), 7.66-$ $7.56(\mathrm{~m}, 3 \mathrm{H}), 7.47\left(\mathrm{t}, \mathrm{J}=7, \mathrm{~J}_{\mathrm{Pt}-\mathrm{H}}=36,2 \mathrm{H}, \mathrm{Ar}\right), 7.10(\mathrm{td}, \mathrm{J}=8,2,2 \mathrm{H}), 6.88(\mathrm{t}, \mathrm{J}=7,1 \mathrm{H}), 3.49-3.40(\mathrm{~m}, 1 \mathrm{H})$, 3.32-3.16 (m, 1H), 2.86-2.74 (m, 1H), 2.74-2.53 (m, 1H), 2.44-2.24 (m, 2H), 2.13-1.97 (m, 2H), 1.94-1.82 (m, 1H), 1.82-1.72 (m, 1H), 1.64-1.54 (m, 1H), 1.45 (dd, J = 19, 7, 3H, Me), 1.19 (dd, J = 19, 7, 3H, Me), 0.94-0.87 (m, 6H, Me), 0.84-0.74 (m, 1H). ${ }^{13} \mathrm{C}\left\{{ }^{1} \mathrm{H}\right\}$ NMR $\left(\mathrm{CD}_{2} \mathrm{Cl}_{2}\right): \delta 138.3(\mathrm{Ph}), 132.9(\mathrm{~d}, \mathrm{~J}=13, \mathrm{Ar})$, 132.6 (m, Ar), 131.6-131.4 (m, Ar), 127.7 (d, J = 7, Ph), $122.9(\mathrm{Ph}), 41.7$ (d, J = 7), 41.5, 37.6, $37.0(\mathrm{~d}, \mathrm{~J}=$ 3), 36.5, $35.8(\mathrm{~d}, \mathrm{~J}=29), 35.2(\mathrm{~d}, \mathrm{~J}=6), 33.2(\mathrm{~d}, \mathrm{~J}=38), 17.2(\mathrm{~d}, \mathrm{~J}=9, \mathrm{Me}), 16.0(\mathrm{~d}, \mathrm{~J}=5, \mathrm{Me}), 14.3(\mathrm{~d}, \mathrm{~J}$ $=19,2 \mathrm{Me}$ ). The quaternary aryl carbons were not observed.

Addition of benzyl bromide to $\mathrm{Pt}((\mathrm{R}, \mathrm{R})-\mathrm{Me}-\mathrm{Duphos})(\mathrm{Ph})(\mathrm{PMeIs})$ (modified workup and measurement of the ee of the phosphine product). A solution of $\mathrm{Pt}((\mathrm{R}, \mathrm{R})-\mathrm{Me}-\mathrm{Duphos})(\mathrm{Ph})(\mathrm{PMeIs})$ $(82.7 \mathrm{mg}, 0.1 \mathrm{mmol})$ in toluene $(0.5 \mathrm{~mL})$ was transferred into an NMR tube, which was fitted with a septum. The tube was cooled in a $\mathrm{NaCl} /$ ice bath at $-5^{\circ} \mathrm{C}$. Benzyl bromide $(17 \mathrm{mg}, 12 \mu \mathrm{L}, 0.1 \mathrm{mmol})$ was added via a microliter syringe. The reaction mixture was kept at $-5^{\circ} \mathrm{C}$ for $6 \mathrm{~h}$, and at $-15^{\circ} \mathrm{C}$ for $15 \mathrm{~h}$, when the reaction was complete, according to ${ }^{31} \mathrm{P}$ NMR. $\mathrm{Pt}(\mathrm{Me}-\mathrm{Duphos})(\mathrm{Ph})(\mathrm{Br})$ and $\mathrm{PMeIs}\left(\mathrm{CH}_{2} \mathrm{Ph}\right)(\delta-40.4)$ were the only components of the mixture observed in toluene; no precipitate was observed.

The solvent was removed under vacuum and $0.5 \mathrm{~mL}$ of a 9:1 mixture of petroleum ether:THF was added to the residue. A white precipitate was formed. The precipitate was washed with 5 portions of $0.5 \mathrm{~mL}$ of the 9:1 mixture of petroleum ether:THF. The washes were collected and the solvent was removed under vacuum. The tertiary phosphine was isolated by filtration on a silica column ( $5 \mathrm{~cm}$ height, $0.6 \mathrm{~cm}$ diameter), using a 9:1 petroleum ether:THF mixture as eluent, followed by solvent removal under vacuum, yielding 21 mg of colorless liquid (62\% yield, $79 \%$ ee). In an analogous experiment carried out at room temperature, the phosphine PMeIs $\left(\mathrm{CH}_{2} \mathrm{Ph}\right)(70 \%$ ee) was isolated in $45 \%$ yield.

The white precipitate was dried under vacuum, yielding $68 \mathrm{mg}$ of white powder that consisted of $\mathrm{Pt}(\mathrm{Me}-$ Duphos $)(\mathrm{Ph})(\mathrm{Br})$ contaminated by PMeIs $\left(\mathrm{CH}_{2} \mathrm{Ph}\right)$, according to the ${ }^{31} \mathrm{P}$ NMR spectrum. A 9:1 mixture of 
petroleum ether:THF ( $1 \mathrm{~mL})$ was added to the residue, and the remaining tertiary phosphine was separated from the Pt compound by filtration on a silica column $(5 \mathrm{~cm}$ height, $0.6 \mathrm{~cm}$ diameter), using a 9:1 petroleum ether:THF mixture as eluent, followed by solvent removal under vacuum, yielding $9 \mathrm{mg}$ of colorless liquid (88\% total yield). $\mathrm{Pt}(\mathrm{Me}-\mathrm{Duphos})(\mathrm{Ph})(\mathrm{Br})$ was removed from the silica by elution with 6 portions of $0.5 \mathrm{~mL}$ of THF, followed by solvent removal under vacuum, yielding $55 \mathrm{mg}$ of off-white powder of the Pt-bromide complex, contaminated by $\sim 5 \%$ PMeIs $\left(\mathrm{CH}_{2} \mathrm{Ph}\right)$, according to ${ }^{31} \mathrm{P} \mathrm{NMR}$ spectroscopy. $\operatorname{Pt}\left(\right.$ Me-Duphos) $(\mathbf{P h})(\mathrm{Br}) .{ }^{31} \mathrm{P}\left\{{ }^{1} \mathrm{H}\right\}$ NMR (toluene): $\delta 65.1\left(\mathrm{~d}, \mathrm{~J}=6, \mathrm{~J}_{\mathrm{Pt}-\mathrm{P}}=1616\right), 56.1$ $\left(\mathrm{d}, \mathrm{J}=6, \mathrm{~J}_{\mathrm{Pt}-\mathrm{P}}=3890\right)$.

\section{Stoichiometric reaction of $\mathrm{Pt}((\mathrm{R}, \mathrm{R})-\mathrm{Me}-\mathrm{Duphos})(\mathrm{Ph})(\mathrm{PMeIs})$ with benzyl bromide, followed}

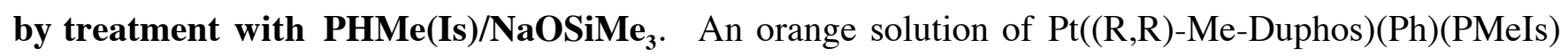
(33 mg, $0.04 \mathrm{mmol})$ in toluene $(5 \mathrm{~mL})$ was transferred into an NMR tube, which was fitted with a septum. Benzyl bromide $(7 \mathrm{mg}, 5 \mu \mathrm{L}, 0.04 \mathrm{mmol}$ ) was added via a microliter syringe. After 10 min the color bleached and the reaction was almost complete according to ${ }^{31} \mathrm{P}$ NMR spectroscopy. $\mathrm{Pt}(\mathrm{Me}-$ Duphos $)(\mathrm{Ph})(\mathrm{Br})$ and $\mathrm{PMeIs}\left(\mathrm{CH}_{2} \mathrm{Ph}\right)$ were observed, plus a trace of the starting material phosphido complex.

The reaction mixture was added to 1 equiv of PHMe(Is) (10 mg, $0.04 \mathrm{mmol})$. Initially, the solution turned yellow, but after $\sim 30 \mathrm{sec}$ the color bleached again. The ${ }^{31} \mathrm{P}$ NMR spectrum showed $\mathrm{Pt}(\mathrm{Me}-$ Duphos $)(\mathrm{Ph})(\mathrm{Br}), \mathrm{PMeIs}\left(\mathrm{CH}_{2} \mathrm{Ph}\right)$ and PHMeIs (ratio tertiary:secondary phosphine $\left.\sim 1: 1\right)$. The mixture was added to 1 equiv of $\mathrm{NaOSiMe}_{3}(5 \mathrm{mg}, 0.04 \mathrm{mmol})$. The color turned orange, and a small amount of precipitate was observed. As indicated by ${ }^{31} \mathrm{P}$ NMR spectroscopy, the main components of the mixture were $\mathrm{Pt}((\mathrm{R}, \mathrm{R})-\mathrm{Me}-\mathrm{Duphos})(\mathrm{Ph})(\mathrm{PMeIs})$ ( $60 \%$ of the Pt species) and $\mathrm{PMeIs}\left(\mathrm{CH}_{2} \mathrm{Ph}\right)$, along with $\mathrm{Pt}(\mathrm{Me}-$ Duphos $)(\mathrm{Ph})(\mathrm{Br})$ and a small amount of $\left[\mathrm{Pt}((\mathrm{R}, \mathrm{R})-\mathrm{Me}-\mathrm{Duphos})(\mathrm{Ph})\left(\mathrm{PMeIs}\left(\mathrm{CH}_{2} \mathrm{Ph}\right)\right)\right][\mathrm{Br}](\sim 10 \%$ of the Pt species). This is consistent with the presence of a slight excess of benzyl bromide, which was shown to react with $\mathrm{Pt}((\mathrm{R}, \mathrm{R})-\mathrm{Me}-\mathrm{Duphos})(\mathrm{Ph})(\mathrm{PMeIs})$ under similar conditions to yield $\mathrm{Pt}(\mathrm{Me}-\mathrm{Duphos})(\mathrm{Ph})(\mathrm{Br})$ and the cation.

\section{Generation of $\operatorname{Pt}((\mathrm{R}, \mathrm{R})-\mathrm{Me}-\mathrm{Duphos})(\mathrm{Ph})(\mathrm{PMeIs})$ and its subsequent reactions with benzyl}

bromide and PHMe(Is)/NaOSiMe ${ }_{3}$. A solution of PHMe(Is) (10 mg, $\left.0.04 \mathrm{mmol}\right)$ in $0.2 \mathrm{~mL}$ of toluene was added to a suspension of $\mathrm{NaOSiMe}_{3}(5 \mathrm{mg}, 0.04 \mathrm{mmol})$ in $0.2 \mathrm{~mL}$ of toluene. The resulting colorless solution was added to a suspension of $\mathrm{Pt}(\mathrm{Me}-\mathrm{Duphos})(\mathrm{Ph})(\mathrm{Cl})(25 \mathrm{mg}, 0.04 \mathrm{mmol})$ in $0.1 \mathrm{~mL}$ of toluene. 
The color turned yellow immediately, indicating the formation of $\mathrm{Pt}((\mathrm{R}, \mathrm{R})-\mathrm{Me}-\mathrm{Duphos})(\mathrm{Ph})(\mathrm{PMeIs})$. The mixture was transferred into an NMR tube, which was fitted with a septum. Benzyl bromide (7 mg, $5 \mu \mathrm{L}$, $0.04 \mathrm{mmol}$ ) was added via a microliter syringe. The color bleached in less than $5 \mathrm{~min}$, and the major components of the mixture, observed by ${ }^{31} \mathrm{P}$ NMR spectroscopy, were $\mathrm{Pt}(\mathrm{Me}-\mathrm{Duphos})(\mathrm{Ph})(\mathrm{Br})$ and PMeIs $\left(\mathrm{CH}_{2} \mathrm{Ph}\right)$. A small amount of $\left[\mathrm{Pt}((\mathrm{R}, \mathrm{R})-\mathrm{Me}-\mathrm{Duphos})(\mathrm{Ph})\left(\mathrm{PMeIs}\left(\mathrm{CH}_{2} \mathrm{Ph}\right)\right)\right][\mathrm{Br}]$ and $\mathrm{Pt}((\mathrm{R}, \mathrm{R})-\mathrm{Me}-$ Duphos)(Ph)(PMeIs) was also observed, presumably because a substoichiometric amount of benzyl bromide was added.

$\mathrm{NaOSiMe}_{3}(5 \mathrm{mg}, 0.04 \mathrm{mmol})$ and PHMe(Is) $(10 \mathrm{mg}, 0.04 \mathrm{mmol})$ were added to the reaction mixture. The color turned yellow immediately, and ${ }^{31} \mathrm{P}$ NMR spectroscopy showed that $\operatorname{Pt}((\mathrm{R}, \mathrm{R})-\mathrm{Me}-$ Duphos)(Ph)(PMeIs) and PMeIs $\left(\mathrm{CH}_{2} \mathrm{Ph}\right)$ were the main components of the mixture, along with a small amount of $\left[\mathrm{Pt}((\mathrm{R}, \mathrm{R})-\mathrm{Me}-\mathrm{Duphos})(\mathrm{Ph})\left(\mathrm{PMeIs}\left(\mathrm{CH}_{2} \mathrm{Ph}\right)\right)\right][\mathrm{Br}] \quad$ and $\mathrm{PHMe}(\mathrm{Is})$ (ratio PMeIs $\left.\left(\mathrm{CH}_{2} \mathrm{Ph}\right): \mathrm{PHMe}(\mathrm{Is})=1.9: 1\right)$. Evidently a slight excess of the secondary phosphine was added.

$[\operatorname{Pt}((\mathbf{R}, \mathbf{R})-$ Me-Duphos $)(\mathrm{Ph})(\mathbf{N C M e})]\left[\mathrm{BF}_{4}\right]$ To a stirring solution of $\mathrm{Pt}((\mathrm{R}, \mathrm{R})-\mathrm{Me}-\mathrm{Duphos})(\mathrm{Ph})(\mathrm{Cl})$ (92.1 mg, $0.15 \mathrm{mmol})$ in $\mathrm{MeCN}(15 \mathrm{~mL})$ was added $\mathrm{AgBF}_{4}(29.2 \mathrm{mg}, 0.15 \mathrm{mmol})$. An off-white precipitate formed immediately, which turned black over time. The mixture was filtered through Celite, yielding a pale brown solution. The solvent was removed under vacuum, and petroleum ether $(5 \mathrm{~mL}) \mathrm{was}$ added to the pale brown residue. A pale brown precipitate formed. The solvent was removed with a pipette and the precipitate was dried under vacuum, yielding $105 \mathrm{mg}$ (99\%) of off-brown powder. The solid was redissolved in $\mathrm{CH}_{2} \mathrm{Cl}_{2}$ and filtered through Celite, yielding a colorless solution. The solvent was removed under vacuum, and the white residue was washed with $5 \mathrm{~mL}$ of petroleum ether and dried under vacuum, yielding an off-white powder. This complex was not obtained in analytically pure form, presumably because of the presence of trace silver salts (brown color), but it could be used successfully (either as generated, or after isolation) to prepare cation 7 by displacement of $\mathrm{MeCN}$ with the phosphine PMeIs $\left(\mathrm{CH}_{2} \mathrm{Ph}\right)$. Anal. Calcd. for $\mathrm{C}_{26} \mathrm{H}_{36} \mathrm{NP}_{2} \mathrm{PtBF}_{4}$ : C, 44.21; H, 5.14; N, 1.98. Anal. Calcd. for $\mathrm{C}_{26} \mathrm{H}_{36} \mathrm{NP}_{2} \mathrm{PtBF}_{4} \bullet 0.05 \mathrm{AgCl}: \mathrm{C}, 43.76 ; \mathrm{H}, 5.09 ; \mathrm{N}, 1.96$. Found: C, 43.55; H, 5.08; N, 1.57. HRMS m/z calcd for $\left(\mathrm{C}_{26} \mathrm{H}_{36} \mathrm{NP}_{2} \mathrm{Pt}\right)^{+}\left(\mathrm{M}^{+}\right)$: 618.1950. Found: 618.1949.

\footnotetext{
${ }^{31} \mathrm{P}\left\{{ }^{1} \mathrm{H}\right\} \mathrm{NMR}\left(\mathrm{CD}_{2} \mathrm{Cl}_{2}\right): \delta 71.4\left(\mathrm{~d}, \mathrm{~J}=4, \mathrm{~J}_{\mathrm{Pt}-\mathrm{P}}=1656\right), 50.5\left(\mathrm{~d}, \mathrm{~J}=4, \mathrm{~J}_{\mathrm{Pt}-\mathrm{P}}=4085\right) .{ }^{1} \mathrm{H} \mathrm{NMR}\left(\mathrm{CD}_{2} \mathrm{Cl}_{2}\right)$ : ठ 7.84-7.78 (m, 1H), 7.75-7.68 (m, 3H), 7.50-7.46 (m, $\left.\mathrm{J}_{\mathrm{Pt}-\mathrm{H}}=35,2 \mathrm{H}\right), 7.24-7.20(\mathrm{~m}, 2 \mathrm{H}), 7.04(\mathrm{t}, \mathrm{J}=8$, $1 \mathrm{H}), 3.24-3.12(\mathrm{~m}, 1 \mathrm{H}), 3.02-2.89(\mathrm{~m}, 2 \mathrm{H}), 2.76-2.64(\mathrm{~m}, 1 \mathrm{H}), 2.57-2.42(\mathrm{~m}, 2 \mathrm{H}), 2.44\left(3 \mathrm{H}, \mathrm{NCCH}_{3}\right)$,
} 
2.14-2.04 (m, 1H), 2.02-1.89 (m, 1H), 1.88-1.77 (m, 1H), 1.72-1.57 (m, 2H), $1.41\left(\mathrm{dd}, \mathrm{J}=19,7,3 \mathrm{H}, \mathrm{CH}_{3}\right)$, $1.21\left(\mathrm{dd}, \mathrm{J}=19,7,3 \mathrm{H}, \mathrm{CH}_{3}\right), 0.98-0.89\left(\mathrm{~m}, 6 \mathrm{H}, 2 \mathrm{CH}_{3}\right), 0.82-0.70(\mathrm{~m}, 1 \mathrm{H}) .{ }^{13} \mathrm{C}\left\{{ }^{1} \mathrm{H}\right\} \mathrm{NMR}\left(\mathrm{CD}_{2} \mathrm{Cl}_{2}\right): \delta$ 155.6 (dd, $\mathrm{J}=101,8$, quat), 141.5 (dd, $\mathrm{J}=54,36$, quat), 138.5 (dd, $\mathrm{J}=42,21$, quat), 137.4 (Ar), 133.6 (d, $\mathrm{J}$ $=11, \operatorname{Ar}), 133.0(\mathrm{~d}, \mathrm{~J}=5, \operatorname{Ar}), 132.9-132.8(\mathrm{~m}, \operatorname{Ar}), 128.5\left(\mathrm{~d}, \mathrm{~J}=6, \mathrm{~J}_{\mathrm{Pt}-\mathrm{C}}=42, \operatorname{Ar}\right), 124.6(\operatorname{Ar}), 123.9(\mathrm{~d}, \mathrm{~J}=$ 6, $\mathrm{CN}$ ), $41.8(\mathrm{~d}, \mathrm{~J}=42, \mathrm{CH}), 40.7(\mathrm{~d}, \mathrm{~J}=29, \mathrm{CH}), 37.1$ (overlapping $\left.\mathrm{d}, \mathrm{J}=28, \mathrm{CH}+\mathrm{CH}_{2}\right), 36.8(\mathrm{~d}, \mathrm{~J}=5$, $\left.\mathrm{CH}_{2}\right), 36.4\left(\mathrm{CH}_{2}\right), 35.0\left(\mathrm{~d}, \mathrm{~J}=6, \mathrm{CH}_{2}\right), 33.7(\mathrm{~d}, \mathrm{~J}=40, \mathrm{CH}), 17.7\left(\mathrm{~d}, \mathrm{~J}=8, \mathrm{CH}_{3}\right), 16.0\left(\mathrm{~d}, \mathrm{~J}=3, \mathrm{~J}_{\mathrm{Pt}-\mathrm{C}}=40\right.$, $\left.\mathrm{CH}_{3}\right), 14.2\left(\mathrm{~d}, \mathrm{~J}=3, \mathrm{CH}_{3}\right), 14.0\left(\mathrm{~d}, \mathrm{~J}=2, \mathrm{CH}_{3}\right), 3.7\left(\mathrm{NCCH}_{3}\right)$.

$\left[\operatorname{Pt}((\mathbf{R}, \mathbf{R})-M e-D u p h o s)(\operatorname{Ph})\left(\mathbf{P M e I s}\left(\mathrm{CH}_{2} \mathbf{P h}\right)\right)\right]\left[\mathrm{BF}_{4}\right](\mathbf{7})$. To a stirring solution of $[\mathrm{Pt}((\mathrm{R}, \mathrm{R})-\mathrm{Me}-$ Duphos) $(\mathrm{Ph})(\mathrm{NCMe})]\left[\mathrm{BF}_{4}\right](66.4 \mathrm{mg}, 0.94 \mathrm{mmol})$ in $\mathrm{MeCN}(15 \mathrm{~mL})$ was added $\mathrm{PMeIs}\left(\mathrm{CH}_{2} \mathrm{Ph}\right)(31 \mathrm{mg}$, $0.94 \mathrm{mmol})$, which was prepared catalytically at $-5{ }^{\circ} \mathrm{C}(82 \%$ ee $)$. The solvent was removed under vacuum, and petroleum ether $(5 \mathrm{~mL})$ was added to the white residue. A white precipitate formed. The solvent was removed with a pipette and the precipitate was dried under vacuum, yielding $90 \mathrm{mg}$ (95\%) of white powder. [Note: if a trace of silver salts remained in the nitrile complex precursor (see above), then a small amount of what appears to be the silver-phosphine complex $\left[\mathrm{Ag}\left(\mathrm{PMeIs}\left(\mathrm{CH}_{2} \mathrm{Ph}\right)\right)\right]^{+}$was also formed $\left({ }^{31} \mathrm{P}\left\{{ }^{1} \mathrm{H}\right\} \mathrm{NMR}\right.$ $\left.\left(\mathrm{CD}_{2} \mathrm{Cl}_{2}\right): \delta-17.4, \mathrm{~J}\left({ }^{107} \mathrm{Ag}-\mathrm{P}\right)=528, \mathrm{~J}\left({ }^{107} \mathrm{Ag}-\mathrm{P}\right)=616\right)$.] Recrystallization from $\mathrm{CH}_{2} \mathrm{Cl}_{2} / \mathrm{Et}_{2} \mathrm{O}$ gave crystals suitable for X-ray crystallography and elemental analyses. Anal. Calcd. for $\mathrm{C}_{47} \mathrm{H}_{66} \mathrm{P}_{3} \mathrm{PtBF}_{4}$ : C, 56.12; H, 6.61. Found: C, 55.74; H, 6.70. HRMS m/z calcd for $\mathrm{C}_{47} \mathrm{H}_{66} \mathrm{P}_{3} \mathrm{Pt}^{+}\left(\mathrm{M}^{+}\right)$: 917.4004. Found: 917.4011.

${ }^{31} \mathrm{P}$ NMR spectroscopy showed a mixture of two diastereomers $\mathbf{a}$ and $\mathbf{b}$ (ratio $\mathbf{a}: \mathbf{b} \sim 10: 1$ ). The following NMR spectra are reported for the major diastereomer a unless otherwise indicated. ${ }^{31} \mathrm{P}\left\{{ }^{1} \mathrm{H}\right\} \mathrm{NMR}$ $\left(\mathrm{CD}_{2} \mathrm{Cl}_{2}, 21^{\circ} \mathrm{C}\right)$ : diastereomer $\mathbf{a}: \delta 64.7\left(\right.$ broad, $\left.\mathrm{J}_{\mathrm{Pt}-\mathrm{P}}=1705\right), 58.2\left(\mathrm{dd}, \mathrm{J}=370,6, \mathrm{~J}_{\mathrm{Pt}-\mathrm{P}}=2443\right), 0.1(\mathrm{~d}, \mathrm{~J}=$ $\left.370, \mathrm{~J}_{\mathrm{Pt}-\mathrm{P}}=2500\right)$; diastereomer b: $\delta 58.25\left(\mathrm{dd}, \mathrm{J}=366,8, \mathrm{~J}_{\mathrm{Pt}-\mathrm{P}}=2459\right), 59.2\left(\mathrm{broad}, \mathrm{J}_{\mathrm{Pt}-\mathrm{P}} \sim 1730\right),-5.7(\mathrm{~d}, \mathrm{~J}$ = 366). ${ }^{1} \mathrm{H}$ NMR $\left(\mathrm{CD}_{2} \mathrm{Cl}_{2}, 21{ }^{\circ} \mathrm{C}\right): \delta 7.99-7.95(\mathrm{~m}, 1 \mathrm{H}), 7.81-7.75(\mathrm{~m}, 1 \mathrm{H}), 7.75-7.66(\mathrm{~m}, 3 \mathrm{H}), 7.34(\mathrm{~m}$, $\left.\mathrm{J}_{\mathrm{Pt}-\mathrm{P}}=35,1 \mathrm{H}\right), 7.26(\mathrm{broad}, 1 \mathrm{H}), 7.18(\mathrm{t}, \mathrm{J}=8,1 \mathrm{H}), 7.16-7.11(\mathrm{~m}, 1 \mathrm{H}), 7.07(\mathrm{t}, \mathrm{J}=8,2 \mathrm{H}), 6.85(\mathrm{t}, \mathrm{J}=7$, 1H), 6.77 (broad, 1H), 6.65 (broad, 1H), 6.45 (1H, Ar), 6.44 (1H, Ar), 4.22 (broad, 1H), 3.94 (broad, 1H, P- $\mathrm{CH}_{2}$ ), 3.22 (broad d, J = 12, 1H, P-CH $\mathrm{CH}_{2}$, 3.20-3.06 (overlapping m, 2H), 3.00-2.83 (m, 2H), 2.71-2.53 (broad m, 2H), 2.29-2.16 (broad m, 1H), 2.14-1.88 (m, 5H), 1.85-1.74 (m, 2H), 1.55-1.47 (broad m, 9H, $\mathrm{CH}_{3}$ ), 1.292 (d, J = 7, 3H, $\mathrm{CH}_{3}$, Is), 1.288 (d, J = 7, 3H, $\mathrm{CH}_{3}$, Is), 1.19 (dd, J = 19, 8, 6H, $\mathrm{CH}_{3}$ ), 1.28-1.17 (m, $3 \mathrm{H}, \mathrm{P}-\mathrm{CH}_{3}$, overlapping the other peaks), $0.80\left(\mathrm{dd}, \mathrm{J}=16,7,3 \mathrm{H}, \mathrm{CH}_{3}\right), 0.36\left(\right.$ broad, $\left.3 \mathrm{H}, \mathrm{CH}_{3}\right), 0.12$ 
(broad, $\left.3 \mathrm{H}, \mathrm{CH}_{3}\right) .{ }^{13} \mathrm{C}\left\{{ }^{1} \mathrm{H}\right\} \operatorname{NMR}\left(\mathrm{CD}_{2} \mathrm{Cl}_{2}, 21{ }^{\circ} \mathrm{C}\right): \delta 155.2$ (m, quat), 152.7 (m, quat), 151.0-150.7 (m, quat), 141.6-141.3 (m, quat), 138.8-138.4 (m, quat), 134.3-133.9 (m, Ar), 133.6 (d, J = 5, Ar), 133.5 (d, J = 5, Ar), 133.2 (broad, Ar), 133.1-132.8 (m, Ar), 132.6 (broad, Ar), 130.1 (m, Ar), 128.6 (m, Ar), 128.0-127.6 (broad m, Ar), 124.8 (broad, Ar), 123.7 (m, Ar), 123.4 (m, Ar), 44.8-44.1 (m), 42.9-42.3 (m), 41.1-40.6 (m), $39.7(\mathrm{dd}, \mathrm{J}=26,3), 37.9-37.6$ (broad m), 37.1 (broad), 36.1, 35.0-34.8 (m), $34.4(\mathrm{~d}, \mathrm{~J}=7)$ overlapping with 34.6-34.0 (broad), 33.0 (dd, J 35, 5, CH), 29.6 (broad), 27.9 (broad), 25.6, 25.1-24.8 (broad m), $23.9(\mathrm{~d}, \mathrm{~J}=4)$ overlapping with 24.1-23.6 (broad m), 18.9-18.6 (m), 15.5-15.1 (m), $14.8(\mathrm{~d}, \mathrm{~J}=$ 6), 14.6, 13.8-13.2(m).

${ }^{31} \mathrm{P}\left\{{ }^{1} \mathrm{H}\right\} \mathrm{NMR}\left(\mathrm{CD}_{2} \mathrm{Cl}_{2},-20{ }^{\circ} \mathrm{C}\right)$ : diastereomer $\mathbf{a}: \delta 64.4\left(\mathrm{dd}, \mathrm{J}=14,6, \mathrm{~J}_{\mathrm{Pt}-\mathrm{P}}=1695\right), 57.9(\mathrm{dd}, \mathrm{J}=368$, $\left.6, \mathrm{~J}_{\mathrm{Pt}-\mathrm{P}}=2434\right), 0.9\left(\mathrm{dd}, \mathrm{J}=368,14, \mathrm{~J}_{\mathrm{Pt}-\mathrm{P}}=2490\right)$; diastereomer $\mathbf{b}: \delta 58.6\left(\mathrm{dd}, \mathrm{J}=17,7, \mathrm{~J}_{\mathrm{Pt}-\mathrm{P}}=1731\right), 58.1$ $\left(\mathrm{dd}, \mathrm{J}=364,7, \mathrm{~J}_{\mathrm{Pt}-\mathrm{P}}=2448\right),-5.7\left(\mathrm{~d}, \mathrm{~J}=364, \mathrm{~J}_{\mathrm{Pt}-\mathrm{P}}=2563\right.$, overlapping the satellite peaks of diastereomer a). ${ }^{1} \mathrm{H}$ NMR $\left(\mathrm{CD}_{2} \mathrm{Cl}_{2},-20{ }^{\circ} \mathrm{C}\right)$ : $\delta$ 7.96-7.93 (m, $\left.1 \mathrm{H}\right), 7.80-7.74(\mathrm{~m}, 1 \mathrm{H}), 7.74-7.63(\mathrm{~m}, 3 \mathrm{H}), 7.39-7.27(\mathrm{~m}$, 1H), $7.24(\mathrm{~m}, 1 \mathrm{H}), 7.16(\mathrm{t}, \mathrm{J}=8,1 \mathrm{H}), 7.14-7.07(\mathrm{~m}, 1 \mathrm{H}), 7.07-6.96(\mathrm{~m}, 2 \mathrm{H}), 6.83(\mathrm{t}, \mathrm{J}=8,1 \mathrm{H}), 6.73-6.67$ (broad m, 1H), 6.65-6.60 (broad m, 1H), 6.39 (1H, Ar), 6.38 (1H, Ar), 4.24-4.14 (m, 1H), 3.90 (dd, J = 14, 7, 1H, P-CH ${ }_{2}$ ), 3.16 (dm, J = 14, 1H, P-CH $_{2}, 3.18-3.00$ (overlapping m, 2H), 3.00-2.75 (m, 2H), 2.70-2.47 (m, 2H), 2.24-2.15 (m, 1H), 2.08-1.82 (m, 5H), 1.81-1.70 (m, 2H), $1.56\left(\mathrm{~d}, \mathrm{~J}=7,3 \mathrm{H}, \mathrm{CH}_{3}, \mathrm{Is}\right), 1.51$ (dd, J $\left.=19,7,3 \mathrm{H}, \mathrm{CH}_{3}\right), 1.46$ (d, J = 6, 3H, $\left.\mathrm{CH}_{3}, \mathrm{Is}\right), 1.262$ (d, J = 7, 3H, $\left.\mathrm{CH}_{3}, \mathrm{Is}\right), 1.255$ (d, J = 7, 3H, $\left.\mathrm{CH}_{3}, \mathrm{Is}\right)$, $1.19\left(\mathrm{dd}, \mathrm{J}=16,7,3 \mathrm{H}, \mathrm{CH}_{3}\right), 1.17\left(\mathrm{dd}, \mathrm{J}=19,7,3 \mathrm{H}, \mathrm{CH}_{3}\right), 1.23-1.09\left(\mathrm{~m}, 3 \mathrm{H}, \mathrm{P}_{-} \mathrm{CH}_{3}\right.$, obscured by the other peaks), 0.77 (dd, $\left.\mathrm{J}=16,7,3 \mathrm{H}, \mathrm{CH}_{3}\right), 0.33$ (d, J = 7, 3H, $\left.\mathrm{CH}_{3}, \mathrm{Is}\right), 0.02$ (d, J = 7, 3H, $\mathrm{CH}_{3}$, Is).

\section{Reaction of $\left[\mathrm{Pt}((\mathrm{R}, \mathrm{R})-\mathrm{Me}-\mathrm{Duphos})(\mathrm{Ph})\left(\mathrm{PMeIs}\left(\mathrm{CH}_{2} \mathrm{Ph}\right)\right)\right]\left[\mathrm{BF}_{4}\right]$ with excess $\left[\mathrm{N}(\mathrm{Oct})_{4}\right][\mathrm{Br}]$. A} solution of $\left[\mathrm{N}(\mathrm{Oct})_{4}\right][\mathrm{Br}](41 \mathrm{mg}, 0.075 \mathrm{mmol}, 5$ equiv) in $0.3 \mathrm{~mL}$ of toluene was added to a slurry of $\left[\mathrm{Pt}((\mathrm{R}, \mathrm{R})-\mathrm{Me}-\mathrm{Duphos})(\mathrm{Ph})\left(\mathrm{PMeIs}\left(\mathrm{CH}_{2} \mathrm{Ph}\right)\right)\right]\left[\mathrm{BF}_{4}\right]$ (15 mg, $\left.0.015 \mathrm{mmol}\right)$, highly diastereomerically enriched, in toluene $(0.2 \mathrm{~mL})$. The mixture became a colorless homogeneous solution immediately. It was transferred into an NMR tube, and monitored by ${ }^{31} \mathrm{P}$ NMR spectroscopy. After $30 \mathrm{~min}, \mathrm{Pt}((\mathrm{R}, \mathrm{R})-\mathrm{Me}-$ Duphos $)(\mathrm{Ph})(\mathrm{Br})$ and $\mathrm{PMeIs}\left(\mathrm{CH}_{2} \mathrm{Ph}\right)$ were the only components of the mixture.

\section{${ }^{31} \mathrm{P}$ NMR Monitoring of the catalytic reaction of benzyl bromide with PHMe(Is). To PHMe(Is)} $(150 \mathrm{mg}, 0.6 \mathrm{mmol})$ in $0.2 \mathrm{~mL}$ of toluene was added $\mathrm{NaOSiMe}_{3}(67.3 \mathrm{mg}, 0.6 \mathrm{mmol})$ suspended in $0.2 \mathrm{~mL}$ of toluene. The mixture was added to $\mathrm{Pt}(\mathrm{Me}-\mathrm{Duphos})(\mathrm{Ph})(\mathrm{Cl})(18 \mathrm{mg}, 0.03 \mathrm{mmol})$ as the catalyst precursor $(5 \mathrm{~mol} \%)$ in $0.1 \mathrm{~mL}$ of toluene. The reaction mixture was transferred to an NMR tube. Benzyl 
bromide $(71 \mu \mathrm{L}, 103 \mathrm{mg}, 0.6 \mathrm{mmol})$ was added via microliter syringe, and the reaction mixture was monitored by ${ }^{31} \mathrm{P}$ NMR spectroscopy. After $5 \mathrm{~min}$, $\left[\mathrm{Pt}(\mathrm{Me}-\mathrm{Duphos})(\mathrm{Ph})\left(\mathrm{PMeIs}\left(\mathrm{CH}_{2} \mathrm{Ph}\right)\right)\right][\mathrm{Br}]$ was observed as the resting state of the catalyst. After $1.5 \mathrm{~h}(\sim 10 \%$ conversion), the resting state of the catalyst was the same. An increasing amount of white precipitate was observed as the reaction progressed. The reaction was complete after $18 \mathrm{~h}$, when the Pt species observed by ${ }^{31} \mathrm{P}$ NMR spectroscopy was $\mathrm{Pt}(\mathrm{Me}-$ Duphos $)(\mathrm{Ph})(\mathrm{Br})$ along with several other unidentified species. The catalyst and $\mathrm{NaBr}$ were removed from the reaction mixture on a silica column ( $5 \mathrm{~cm}$ height, $0.6 \mathrm{~cm}$ diameter), using a 9:1 petroleum ether:THF mixture as eluent. The catalyst and $\mathrm{NaBr}$ did not elute. The solvent was removed under vacuum, yielding 95 mg (47\% yield) of tertiary phosphine.

$\left[\operatorname{Pt}(\right.$ Me-Duphos $\left.)(\mathbf{P h})\left(\mathbf{P M e I s}\left(\mathrm{CH}_{2} \mathbf{P h}\right)\right)\right][\mathrm{Br}] .{ }^{31} \mathrm{P}\left\{{ }^{1} \mathrm{H}\right\}$ NMR (toluene): diastereomer a: $\delta 64.5\left(\mathrm{~J}_{\mathrm{Pt}-\mathrm{P}}\right.$ $=1692), 58.1\left(\mathrm{~d}, \mathrm{~J}=369, \mathrm{~J}_{\mathrm{Pt}-\mathrm{P}}=2498\right),-0.2\left(\mathrm{~d}, \mathrm{~J}=369, \mathrm{~J}_{\mathrm{Pt}-\mathrm{P}}=2507\right)$; diastereomer b: $\delta 58.5$ (broad), 58.2 $\left(\mathrm{d}, \mathrm{J}=369, \mathrm{~J}_{\mathrm{Pt}-\mathrm{P}}=2436\right),-6.1(\mathrm{~d}, \mathrm{~J}=369)$.

\section{Stoichiometric reaction of $\left.\left[\operatorname{Pt}((\mathrm{R}, \mathrm{R})-\mathrm{Me}-\mathrm{Duphos})(\mathrm{Ph})\left(\mathrm{PMeIs}\left(\mathrm{CH}_{2} \mathrm{Ph}\right)\right)\right]\right]\left[\mathrm{BF}_{4}\right]$ with}

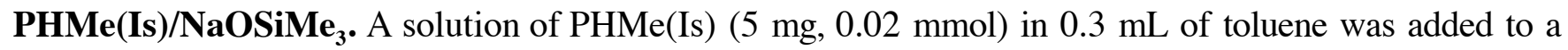
slurry of $\left.\left[\mathrm{Pt}((\mathrm{R}, \mathrm{R})-\mathrm{Me}-\mathrm{Duphos})(\mathrm{Ph})\left(\mathrm{PMeIs}\left(\mathrm{CH}_{2} \mathrm{Ph}\right)\right)\right]\right]\left[\mathrm{BF}_{4}\right](20 \mathrm{mg}, \quad 0.02 \mathrm{mmol}$, highly diastereomerically enriched) in toluene $(0.2 \mathrm{~mL})$. The mixture was transferred into an NMR tube, and monitored by ${ }^{31} \mathrm{P}$ NMR spectroscopy. The cation was soluble enough to give weak NMR signals. A very small amount of PMeIs $\left(\mathrm{CH}_{2} \mathrm{Ph}\right)$ was observed after 2 days. The solution, which contained mostly PHMe(Is), was decanted and the solid was dried under vacuum, yielding $\sim 8 \mathrm{mg}$ of white powder, which was dissolved in $0.5 \mathrm{~mL}$ of $\mathrm{CH}_{2} \mathrm{Cl}_{2}$. The solution was transferred into an NMR tube; it consisted of unreacted $\left[\mathrm{Pt}((\mathrm{R}, \mathrm{R})-\mathrm{Me}-\mathrm{Duphos})(\mathrm{Ph})\left(\mathrm{PMeIs}\left(\mathrm{CH}_{2} \mathrm{Ph}\right)\right)\right]\left[\mathrm{BF}_{4}\right]$ and $\mathrm{PHMe}(\mathrm{Is})$, according to ${ }^{31} \mathrm{P}$ NMR spectroscopy. No reaction was observed after 4 days. PHMe(Is) ( $5 \mathrm{mg}, 0.02 \mathrm{mmol}$ ) was added to the mixture, and the solvent was removed under vacuum, yielding a viscous colorless residue. To this mixture was added a slurry of $\mathrm{NaOSiMe}_{3}(2 \mathrm{mg}, 0.02 \mathrm{mmol})$ in toluene $(0.5 \mathrm{~mL})$. The mixture turned yellow in $\sim 30$ sec. The new mixture was transferred into an NMR tube and monitored by ${ }^{31} \mathrm{P}$ NMR spectroscopy. After $1 \mathrm{~h} \mathrm{Pt}((\mathrm{R}, \mathrm{R})-\mathrm{Me}-\mathrm{Duphos})(\mathrm{Ph})(\mathrm{PMeIs})$ was the only Pt species observed, along with $\mathrm{PMeIsCH}_{2} \mathrm{Ph}$ and unreacted PHMe(Is), indicating that there was an excess of PHMeIs in the system.

Stoichiometric reaction of $\mathrm{Pt}((\mathrm{R}, \mathrm{R})-\mathrm{Me}-\mathrm{Duphos})(\mathrm{Ph})(\mathrm{Br})$ with $\mathrm{PHMe}(\mathrm{Is}), \mathrm{PMeIs}\left(\mathrm{CH}_{2} \mathrm{Ph}\right)$, and $\mathrm{NaOSiMe}_{3}$. A solution of PHMe(Is) $(10 \mathrm{mg}, 0.04 \mathrm{mmol})$ in $0.3 \mathrm{~mL}$ of toluene was added to a solution of 
$\operatorname{Pt}((\mathrm{R}, \mathrm{R})-\mathrm{Me}-\mathrm{Duphos})(\mathrm{Ph})(\mathrm{Br})(26.3 \mathrm{mg}, 0.04 \mathrm{mmol})$ in toluene $(0.2 \mathrm{~mL})$. The mixture was transferred into an NMR tube, and monitored by ${ }^{31} \mathrm{P}$ NMR spectroscopy. No reaction was observed after $1 \mathrm{~h}$, the only species present in the mixture being the starting materials. The solution was added to $\mathrm{PMeIs}\left(\mathrm{CH}_{2} \mathrm{Ph}\right)$ (13.6 mg, $0.04 \mathrm{mmol}$ ), and the mixture was transferred into an NMR tube. Monitoring by ${ }^{31} \mathrm{P}$ NMR spectroscopy showed no reaction, even after $1 \mathrm{~d}$. The mixture was then added to $\mathrm{NaOSiMe}_{3}(4.5 \mathrm{mg}, 0.04$ mmol). The color of the solution turned yellow immediately. After 5 min the only Pt species observed by

${ }^{31} \mathrm{P}$ NMR spectroscopy was $\mathrm{Pt}((\mathrm{R}, \mathrm{R})-\mathrm{Me}-\mathrm{Duphos})(\mathrm{Ph})(\mathrm{PMeIs})$. The ratio $\mathrm{PHMe}(\mathrm{Is}): \mathrm{PMeIs}\left(\mathrm{CH}_{2} \mathrm{Ph}\right)$ was $\sim 1: 2.6$, indicating that there was an excess of PHMe(Is) in the system.

Reaction of Benzyl Chloride with PHMe(Is) in the Absence of a Catalyst To PHMe(Is) (25 mg, $0.1 \mathrm{mmol})$ in $0.2 \mathrm{~mL}$ of toluene was added $\mathrm{NaOSiMe}_{3}(11.2 \mathrm{mg}, 0.1 \mathrm{mmol})$ suspended in $0.3 \mathrm{~mL}$ of toluene. The reaction mixture was transferred to an NMR tube. Benzyl chloride (12 $\mu \mathrm{L}, 13 \mathrm{mg}, 0.1 \mathrm{mmol})$ was added via microliter syringe, and the reaction mixture was monitored by ${ }^{31} \mathrm{P}$ NMR spectroscopy. Formation of a white precipitate was observed as the reaction progressed. After 1 month conversion was $\sim 20 \%$. In addition to the product PMeIs $\left(\mathrm{CH}_{2} \mathrm{Ph}\right)(\delta-41.6)$, another peak $(\delta 40.8)$ was observed, with selectivity $69 \%$.

\section{Catalytic Reaction of Benzyl Chloride with PHMe(Is) for the Synthesis of PMeIs(CH$\left(\mathrm{CH}_{2} \mathrm{Ph}\right.$ (5)} To PHMe(Is) $(25 \mathrm{mg}, 0.1 \mathrm{mmol})$ in $0.2 \mathrm{~mL}$ of toluene was added $\mathrm{NaOSiMe}_{3}(11.2 \mathrm{mg}, 0.1 \mathrm{mmol})$ suspended in $0.2 \mathrm{~mL}$ of toluene. The mixture was added to $\mathrm{Pt}(\mathrm{Me}-\mathrm{Duphos})(\mathrm{Ph})(\mathrm{PMeIs})(4.1 \mathrm{mg}, 0.005$ $\mathrm{mmol}$ ) as the catalyst precursor $(5 \mathrm{~mol} \%)$ in $0.1 \mathrm{~mL}$ of toluene. The reaction mixture was transferred to an NMR tube. Benzyl chloride (12 $\mu \mathrm{L}, 13 \mathrm{mg}, 0.1 \mathrm{mmol})$ was added via microliter syringe, and the reaction mixture was monitored by ${ }^{31} \mathrm{P}$ NMR spectroscopy. An increasing amount of white precipitate was observed as the reaction progressed. The reaction went to completion in $\sim 1$ month. The catalyst and $\mathrm{NaCl}$ were removed from the reaction mixture on a silica column $(14 \mathrm{~cm}$ height, $1 \mathrm{~cm}$ diameter $)$, using a 9:1 petroleum ether:THF mixture as eluent. The catalyst and $\mathrm{NaCl}$ did not elute. The solvent was removed under vacuum and $34 \mathrm{mg}$ (99\% yield) of a colorless oil (70\% ee) was obtained. The tertiary phosphine was dissolved in $0.5 \mathrm{~mL}$ of $\mathrm{C}_{6} \mathrm{D}_{6}$ for spectroscopic characterization.

HRMS m/z calcd. for $\mathrm{C}_{23} \mathrm{H}_{34} \mathrm{P}^{+}\left(\mathrm{MH}^{+}\right)$341.2398. Found, 341.2400. ${ }^{31} \mathrm{P}\left\{{ }^{1} \mathrm{H}\right\}$ NMR $\left(\mathrm{C}_{6} \mathrm{D}_{6}\right): \delta-40.0$ (selectivity 100\%). ${ }^{1} \mathrm{H}$ NMR $\left(\mathrm{C}_{6} \mathrm{D}_{6}\right): \delta 7.18$ (broad, 1H, Ar), 7.16 (broad, 1H, Ar), 7.13 (d, J = 2, 2H, Is), 7.09 (t, J = 7, 2H, Ar), 7.03-6.99 (m, 1H, Ar), 4.15-4.08 (m, 2H, CH), 3.27 (d, J = 14, 1H, $\left.\mathrm{CH}_{2}\right), 3.15(\mathrm{~d}, \mathrm{~J}$ 
$\left.=14,1 \mathrm{H}, \mathrm{CH}_{2}\right), 2.79-2.73(\mathrm{~m}, 1 \mathrm{H}, \mathrm{CH}), 1.41\left(\mathrm{~d}, \mathrm{~J}=7,3 \mathrm{H}, \mathrm{P}-\mathrm{CH}_{3}\right), 1.33\left(\mathrm{~d}, \mathrm{~J}=7,6 \mathrm{H}, \mathrm{CH}_{3}, i-\mathrm{Pr}\right), 1.21(\mathrm{~d}$, $\left.\mathrm{J}=7,6 \mathrm{H}, \mathrm{CH}_{3}, i-\mathrm{Pr}\right), 1.20\left(\mathrm{~d}, \mathrm{~J}=7,6 \mathrm{H}, \mathrm{CH}_{3}, i-\operatorname{Pr}\right) .{ }^{13} \mathrm{C}\left\{{ }^{1} \mathrm{H}\right\} \mathrm{NMR}\left(\mathrm{C}_{6} \mathrm{D}_{6}\right): \delta 156.3(\mathrm{~d}, \mathrm{~J}=14$, quat $), 150.9$ (d, $\mathrm{J}=1$, quat), 140.4 (d, $\mathrm{J}=11$, quat), $131.0(\mathrm{~d}, \mathrm{~J}=26$, quat), 129.8 (d, $\mathrm{J}=6, \operatorname{Ar}), 129.0(\mathrm{~d}, \mathrm{~J}=2, \operatorname{Ar})$, 126.3 (d, J = 3, Ar), 122.7 (d, J = 4, Is), 37.2 (d, J = 18, CH, $i$-Pr), 35.0 (CH, i-Pr), 31.9 (d, J = 21, $\mathrm{CH}_{2}$ ), $25.5\left(2 \mathrm{CH}_{3}\right.$, Is), $25.3\left(2 \mathrm{CH}_{3}\right.$, Is), $24.4\left(2 \mathrm{CH}_{3}, \mathrm{Is}\right), 12.0$ (d, J = 21, $\left.\mathrm{P}-\mathrm{CH}_{3}\right)$.

Reaction of Benzyl Bromide with PHMe(Is) in the Absence of Catalyst To PHMe(Is) (25 mg, $0.1 \mathrm{mmol}$ ) in $0.2 \mathrm{~mL}$ of solvent (toluene or THF) was added $\mathrm{NaOSiMe}_{3}(11.2 \mathrm{mg}, 0.1 \mathrm{mmol}$ ) suspended in $0.3 \mathrm{~mL}$ of solvent. The reaction mixture was transferred to an NMR tube. Benzyl bromide (12 $\mu \mathrm{L}, 17$ $\mathrm{mg}, 0.1 \mathrm{mmol}$ ) was added via microliter syringe, and the reaction mixture was monitored by ${ }^{31} \mathrm{P}$ NMR spectroscopy. Formation of a white precipitate was observed as the reaction progressed. In toluene, after 3 weeks, conversion was $\sim 20 \%$ and selectivity $41 \%$ (other peaks $\delta 35.7,35.5,-55.1,-58.4,-83.9$ ). In THF, after 2 weeks conversion was $\sim 33 \%$ and selectivity $49 \%$ (other peaks $\delta 30.7,-59.4,-62.6,-88.9,-111.5$ ).

\section{Catalytic Reaction of Benzyl Bromide with PHMe(Is) Using Different Catalyst Precursors To} PHMe(Is) (25 mg, $0.1 \mathrm{mmol}$ ) in $0.2 \mathrm{~mL}$ of solvent (toluene or THF) was added $\mathrm{NaOSiMe}_{3}(11.2 \mathrm{mg}, 0.1$ mmol) suspended in $0.2 \mathrm{~mL}$ of solvent. The mixture was added to $\operatorname{Pt}(\mathrm{Duphos})(\mathrm{Y})(\mathrm{Z})$ or $\operatorname{Pd}(\mathrm{Me}-$ Duphos $)\left(\mathrm{C}_{6} \mathrm{~F}_{5}\right)(\mathrm{I})(0.005 \mathrm{mmol}$; Table 4$)$ as the catalyst precursor $(5 \mathrm{~mol} \%)$ in $0.1 \mathrm{~mL}$ of solvent. The reaction mixture was transferred to an NMR tube. Benzyl bromide (12 $\mu \mathrm{L}, 17 \mathrm{mg}, 0.1 \mathrm{mmol})$ was added via microliter syringe, and the reaction mixture was monitored by ${ }^{31} \mathrm{P}$ NMR spectroscopy. An increasing amount of white precipitate was observed as the reaction progressed. The catalyst and $\mathrm{NaBr}$ were removed from the reaction mixture on a silica column (14 cm height, $1 \mathrm{~cm}$ diameter), using a 9:1 petroleum ether:THF mixture as eluent. The catalyst and $\mathrm{NaBr}$ did not elute. The solvent was removed under vacuum, and the tertiary phosphine was dissolved in $0.5 \mathrm{~mL}$ of $\mathrm{C}_{6} \mathrm{D}_{6}$ for spectroscopic characterization. 
Table 2. Catalytic asymmetric alkylation of PHMe(Is) with benzyl halides

\begin{tabular}{|c|c|c|c|c|}
\hline Catalyst Precursor & $\begin{array}{l}\text { A mount oun } \\
\text { Catalyst (mg) }\end{array}$ & Time & $\begin{array}{l}\text { Yield } \\
(\%)\end{array}$ & $\begin{array}{l}\mathrm{ee} \\
(\%)\end{array}$ \\
\hline $\mathrm{Pt}(\mathrm{Me}-\mathrm{Duphos})(\mathrm{Ph})(\mathrm{PMeIs})^{b}$ & 4.1 & $3 \mathrm{~h}$ & 99 & 77 \\
\hline 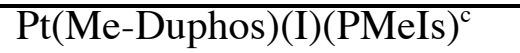 & 4.4 & $4 \mathrm{~h}$ & 92 & 31 \\
\hline $\mathrm{Pt}(\mathrm{Me}-\mathrm{Duphos})(\mathrm{PMeIs})_{2}^{\mathrm{c}, \mathrm{d}}$ & 2.5 & $20 \mathrm{~h}$ & 98 & 24 \\
\hline 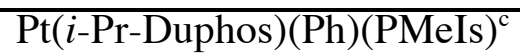 & 4.7 & $24 \mathrm{~h}$ & 99 & -49 \\
\hline $\mathrm{Pt}(\mathrm{Me}-\mathrm{Duphos})(\mathrm{Ph})(\mathrm{Cl})^{\mathrm{c}}$ & 3.1 & $1 \mathrm{~h}$ & 95 & 75 \\
\hline $\mathrm{Pt}(\mathrm{Me}-\mathrm{Duphos})(\mathrm{Ph})(\mathrm{Cl})^{\mathrm{c}, \mathrm{e}}$ & 3.1 & $24 \mathrm{~h}$ & 94 & 83 \\
\hline$\overline{\mathrm{Pt}}(i-\mathrm{Pr}-\mathrm{Duphos})(\mathrm{Ph})(\mathrm{Cl})^{\mathrm{c}}$ & 3.6 & $4 \mathrm{~h}$ & 87 & -45 \\
\hline $\mathrm{Pt}(\mathrm{Me}-\mathrm{Duphos})(\mathrm{Me})(\mathrm{Cl})^{\mathrm{c}}$ & 2.8 & $15 \mathrm{~min}$ & 79 & 38 \\
\hline $\mathrm{Pt}(\mathrm{Me}-\mathrm{Duphos}) \mathrm{Cl}_{2}^{\mathrm{c}, \mathrm{d}}$ & 1.4 & $<20 \mathrm{~h}$ & 85 & 22 \\
\hline $\begin{array}{l}\mathrm{Pt}(\text { Tol-Binap })(\mathrm{Ph})(\mathrm{Cl})^{\mathrm{c}} \\
\end{array}$ & 4.9 & $24 \mathrm{~h}$ & 90 & 61 \\
\hline$\frac{\mathrm{Pt}(\text { Tol-Binap })(\mathrm{Me})(\mathrm{Cl})^{\mathrm{c}}}{}$ & 4.6 & $24 \mathrm{~h}$ & 63 & 52 \\
\hline $\mathrm{Pd}(\mathrm{Me}-$ Duphos $)\left(\mathrm{C}_{6} \mathrm{~F}_{5}\right)(\mathrm{I})^{\mathrm{c}}$ & 3.5 & $24 \mathrm{~h}$ & 85 & 43 \\
\hline
\end{tabular}

${ }^{a}$ General procedure for the reactions was 5 mol\% catalyst loading, 1 equiv of benzyl bromide and $\mathrm{NaOSiMe}_{3}$ per phosphine. Time for completion of the reaction (as determined by ${ }^{31} \mathrm{P}$ NMR monitoring) is reported in $\mathrm{h}$ (hours) or min (min). ${ }^{\mathrm{b}}$ In toluene. ${ }^{\mathrm{c}}$ In THF. ${ }^{\mathrm{d}} 2.5 \mathrm{~mol} \%$ catalyst. ${ }^{\mathrm{e}}$ Reagents were combined at $-10{ }^{\circ} \mathrm{C}$ and, after 1 hour, the reaction was carried out at $-25^{\circ} \mathrm{C}$.

\section{Reaction of 2-Iodobenzyl Bromide with PHMe(Is) in the Absence of Catalyst To PHMe(Is) (25} $\mathrm{mg}, 0.1 \mathrm{mmol})$ in $0.2 \mathrm{~mL}$ of toluene was added $\mathrm{NaOSiMe}_{3}(11.2 \mathrm{mg}, 0.1 \mathrm{mmol})$ suspended in $0.2 \mathrm{~mL}$ of toluene. The mixture was added to $\mathrm{C}_{6} \mathrm{H}_{4}\left(\mathrm{CH}_{2} \mathrm{Br}\right)(o-\mathrm{I})(29.7 \mathrm{mg}, 0.1 \mathrm{mmol})$ in $0.1 \mathrm{~mL}$ of toluene. The reaction mixture was transferred to an NMR tube and monitored by ${ }^{31} \mathrm{P}$ NMR spectroscopy. An increasing amount of white precipitate was observed as the reaction progressed. After $2 \mathrm{~d}$ the conversion was $48 \%$ and selectivity $82 \%$ (other peaks $\delta 41.1,-53.1,-56.4,-88.3$ ).

Catalytic Reaction of 2-Iodobenzyl Bromide with PHMe(Is) To PHMe(Is) (25 mg, $0.1 \mathrm{mmol}$ ) in $0.1 \mathrm{~mL}$ of toluene was added $\mathrm{NaOSiMe}_{3}(11.2 \mathrm{mg}, 0.1 \mathrm{mmol})$ suspended in $0.2 \mathrm{~mL}$ of toluene. The mixture was added to $\mathrm{Pt}(\mathrm{Me}-\mathrm{Duphos})(\mathrm{Ph})(\mathrm{PMeIs})(4.1 \mathrm{mg}, 0.005 \mathrm{mmol})$ as the catalyst precursor (5 $\mathrm{mol} \%)$ in $0.1 \mathrm{~mL}$ of toluene and to $\mathrm{C}_{6} \mathrm{H}_{4}\left(\mathrm{CH}_{2} \mathrm{Br}\right)(o-\mathrm{I})(29.7 \mathrm{mg}, 0.1 \mathrm{mmol})$ in $0.1 \mathrm{~mL}$ of toluene. The reaction mixture was transferred to an NMR tube and monitored by ${ }^{31} \mathrm{P}$ NMR spectroscopy. An increasing 
amount of white precipitate was observed as the reaction progressed. The reaction went to completion in $\sim 1$ d. The catalyst and $\mathrm{NaBr}$ were removed from the reaction mixture on a silica column $(14 \mathrm{~cm}$ height, $1 \mathrm{~cm}$ diameter), using a 9:1 petroleum ether:THF mixture as eluent. The catalyst and $\mathrm{NaBr}$ did not elute. The solvent was removed under vacuum and $41 \mathrm{mg}$ ( $88 \%$ yield) of white crystals $(55 \%$ ee) was obtained. The tertiary phosphine was dissolved in $0.5 \mathrm{~mL}$ of $\mathrm{C}_{6} \mathrm{D}_{6}$ for spectroscopic characterization.

HRMS m/z calcd. for $\mathrm{C}_{23} \mathrm{H}_{33} \mathrm{PI}^{+}\left(\mathrm{MH}^{+}\right)$466.1365. Found, 467.1361. ${ }^{31} \mathrm{P}\left\{{ }^{1} \mathrm{H}\right\} \mathrm{NMR}\left(\mathrm{C}_{6} \mathrm{D}_{6}\right): \delta-40.1$ (selectivity 97\%, other peak -53.3). ${ }^{1} \mathrm{H}$ NMR $\left(\mathrm{C}_{6} \mathrm{D}_{6}\right): \delta 7.70($ broad d, J = 8, 1H, Ar), $7.16(\mathrm{~d}, \mathrm{~J}=2,2 \mathrm{H}$, Is), 6.95 (dt, J = 8, 2, 1H, Ar), 6.82 (broad t, J = 8, 2H, Ar), $6.46($ broad t, J = 8, 1H, Ar), 4.22-4.15 (m, 2H, $\mathrm{CH}, i-\operatorname{Pr}), 3.55\left(\mathrm{~d}, \mathrm{~J}=13,1 \mathrm{H}, \mathrm{CH}_{2}\right), 3.35\left(\mathrm{~d}, \mathrm{~J}=13,1 \mathrm{H}, \mathrm{CH}_{2}\right), 2.79-2.74(\mathrm{~m}, 1 \mathrm{H}, \mathrm{CH}, i-\operatorname{Pr}), 1.48(\mathrm{~d}, \mathrm{~J}=8$, $3 \mathrm{H}, \mathrm{P}-\mathrm{CH}_{3}$ ), 1.34 (d, J = 7, 6H, $\left.\mathrm{CH}_{3}, i-\mathrm{Pr}\right), 1.27$ (d, J = 7, 6H, $\left.\mathrm{CH}_{3}, i-\operatorname{Pr}\right), 1.21$ (d, J = 7, 6H, $\mathrm{CH}_{3}, i-\operatorname{Pr}$ ). ${ }^{13} \mathrm{C}\left\{{ }^{1} \mathrm{H}\right\} \operatorname{NMR}\left(\mathrm{C}_{6} \mathrm{D}_{6}\right): \delta 156.3(\mathrm{~d}, \mathrm{~J}=14$, quat), $151.1(\mathrm{~d}, \mathrm{~J}=1$, quat), $143.6(\mathrm{~d}, \mathrm{~J}=12$, quat), $140.2(\mathrm{~d}, \mathrm{~J}$ = 2, quat), 130.5 (d, J = 8, Ar), 128.7 (m, Ar, obscured by $\mathrm{C}_{6} \mathrm{D}_{6}$ peaks), $128.0(\mathrm{~d}, \mathrm{~J}=3, \mathrm{Ar}), 122.8(\mathrm{~d}, \mathrm{~J}=4$, Is), 102.2 (d, J = 6, C-I), 41.9 (CH, $i$-Pr), 41.7 (CH, $i$-Pr), $35.0\left(\mathrm{CH}, i\right.$-Pr), 32.0 (d, J = 21, $\mathrm{CH}_{2}$ ), 25.7 $\left(2 \mathrm{CH}_{3}, \mathrm{Is}\right), 25.3\left(2 \mathrm{CH}_{3}, \mathrm{Is}\right), 24.4\left(2 \mathrm{CH}_{3}, \mathrm{Is}\right), 11.9$ (d, J = 21, $\left.\mathrm{P}_{-} \mathrm{CH}_{3}\right)$.

\section{Reaction of 2-cyanobenzyl bromide with PHMe(Is) in the Absence of a Catalyst To PHMe(Is)} (25 mg, $0.1 \mathrm{mmol}$ ) in $0.2 \mathrm{~mL}$ of THF was added $\mathrm{NaOSiMe}_{3}(11.2 \mathrm{mg}, 0.1 \mathrm{mmol})$ suspended in $0.2 \mathrm{~mL}$ of THF. The mixture was added to 2-(bromomethyl)benzonitrile (19.6 mg, $0.1 \mathrm{mmol}$ ) in $0.1 \mathrm{~mL}$ of THF. The reaction mixture was transferred to an NMR tube and monitored by ${ }^{31} \mathrm{P}$ NMR spectroscopy. An increasing amount of white precipitate was observed as the reaction progressed. After $20 \mathrm{~h}$ the conversion was $78 \%$ and selectivity $71 \%$ (other peaks $\delta 35.6,28.8,-53.8,-84.6$ ).

Catalytic Reaction of 2-cyanobenzyl bromide with PHMe(Is) To PHMe(Is) (25 mg, $0.1 \mathrm{mmol})$ in $0.1 \mathrm{~mL}$ of THF was added $\mathrm{NaOSiMe}_{3}(11.2 \mathrm{mg}, 0.1 \mathrm{mmol})$ suspended in $0.2 \mathrm{~mL}$ of THF. The mixture was added to $\mathrm{Pt}(\mathrm{Me}-\mathrm{Duphos})(\mathrm{Ph})(\mathrm{Cl})(3.1 \mathrm{mg}, 0.005 \mathrm{mmol})$ as the catalyst precursor $(5 \mathrm{~mol} \%)$ in $0.1 \mathrm{~mL}$ of THF and to 2-(bromomethyl)benzonitrile (19.6 mg, $0.1 \mathrm{mmol})$ in $0.1 \mathrm{~mL}$ of THF. The reaction mixture was transferred to an NMR tube and monitored by ${ }^{31} \mathrm{P}$ NMR spectroscopy. An increasing amount of white precipitate was observed as the reaction progressed. The reaction went to completion in $\sim 15 \mathrm{~min}$. The catalyst and $\mathrm{NaBr}$ were removed from the reaction mixture on a silica column $(5 \mathrm{~cm}$ height, $0.6 \mathrm{~cm}$ diameter), using a 9:1 petroleum ether:THF mixture as eluent. The catalyst and $\mathrm{NaBr}$ did not elute. The 
solvent was removed under vacuum and $31 \mathrm{mg}$ (86\% yield) of colorless liquid ( $50 \%$ ee, see Table 1$)$ was obtained. The tertiary phosphine was dissolved in $0.5 \mathrm{~mL}$ of $\mathrm{C}_{6} \mathrm{D}_{6}$ for spectroscopic characterization.

HRMS m/z calcd. for $\mathrm{C}_{24} \mathrm{H}_{33} \mathrm{NP}^{+}\left(\mathrm{MH}^{+}\right)$366.2351. Found, 366.2339. ${ }^{31} \mathrm{P}\left\{{ }^{1} \mathrm{H}\right\} \mathrm{NMR}\left(\mathrm{C}_{6} \mathrm{D}_{6}\right): \delta-35.6$ (selectivity 100\%). ${ }^{1} \mathrm{H}$ NMR $\left(\mathrm{C}_{6} \mathrm{D}_{6}\right): \delta 7.15(\mathrm{~d}, \mathrm{~J}=3,2 \mathrm{H}, \mathrm{Is}), 7.08(\mathrm{dd}, \mathrm{J}=8,1,1 \mathrm{H}, \mathrm{Ar}), 6.89$ (broad d, J = 8, 1H, Ar), $6.80(\mathrm{td}, \mathrm{J}=8,2,1 \mathrm{H}$, Ar), $6.57(\operatorname{broad} \mathrm{t}, \mathrm{J}=8,1 \mathrm{H}$, Ar), 4.22-4.12 (m, 2H, CH, $i-\operatorname{Pr}), 3.66(\mathrm{~d}, \mathrm{~J}=$ $\left.13,1 \mathrm{H}, \mathrm{CH}_{2}\right), 3.18\left(\mathrm{dd}, \mathrm{J}_{\mathrm{HH}}=13, \mathrm{~J}_{\mathrm{PH}}=2,1 \mathrm{H}, \mathrm{CH}_{2}\right), 2.78-2.71(\mathrm{~m}, 1 \mathrm{H}, \mathrm{CH}, i-\mathrm{Pr}), 1.44\left(\mathrm{~d}, \mathrm{~J}_{\mathrm{PH}}=7,3 \mathrm{H}, \mathrm{P}-\right.$ $\left.\mathrm{CH}_{3}\right), 1.37\left(\mathrm{~d}, \mathrm{~J}=7,6 \mathrm{H}, \mathrm{CH}_{3}, i-\mathrm{Pr}\right), 1.28\left(\mathrm{~d}, \mathrm{~J}=7,6 \mathrm{H}, \mathrm{CH}_{3}, i-\mathrm{Pr}\right), 1.20\left(\mathrm{~d}, \mathrm{~J}=7,6 \mathrm{H}, \mathrm{CH}_{3}, i-\operatorname{Pr}\right) .{ }^{13} \mathrm{C}\left\{{ }^{1} \mathrm{H}\right\}$ $\operatorname{NMR}\left(\mathrm{C}_{6} \mathrm{D}_{6}\right): \delta 156.4(\mathrm{~d}, \mathrm{~J}=14$, quat), $151.4(\mathrm{~d}, \mathrm{~J}=1$, quat), $144.8(\mathrm{~d}, \mathrm{~J}=11$, quat), 133.1 (d, $\mathrm{J}=2, \operatorname{Ar})$, 132.5 (d, J = 2, Ar), 130.4 (d, J = 7, Ar), 126.5 (d, J = 3, Ar), 122.9 (d, J = 4, Is), 113.7 (d, J = 5, CN), 35.4 $\left(\mathrm{d}, \mathrm{J}=21,2 \mathrm{CH}, i\right.$-Pr), $35.0\left(\mathrm{CH}, i\right.$-Pr), $32.0\left(\mathrm{~d}, \mathrm{~J}=21, \mathrm{CH}_{2}\right), 25.6\left(2 \mathrm{CH}_{3}, \mathrm{Is}\right), 25.3\left(2 \mathrm{CH}_{3}, \mathrm{Is}\right), 24.4\left(2 \mathrm{CH}_{3}\right.$, Is), $11.6\left(\mathrm{~d}, \mathrm{~J}=21, \mathrm{P}-\mathrm{CH}_{3}\right)$.

\section{Reaction of 9-Chloromethyl Anthracene with PHMe(Is) in the Absence of a Catalyst To} PHMe(Is) (25 mg, $0.1 \mathrm{mmol})$ in $0.1 \mathrm{~mL}$ of toluene was added $\mathrm{NaOSiMe}_{3}(11.2 \mathrm{mg}, 0.1 \mathrm{mmol})$ suspended in $0.2 \mathrm{~mL}$ of toluene and 9-chloromethyl anthracene $(22.6 \mathrm{mg}, 0.1 \mathrm{mmol})$ in $0.1 \mathrm{~mL}$ of toluene. The reaction mixture was transferred to an NMR tube and monitored by ${ }^{31} \mathrm{P}$ NMR spectroscopy. Formation of a white precipitate was observed as the reaction progressed. After 1 week, conversion was $\sim 36 \%$ and selectivity $72 \%$ (other peaks $\delta 36.9$ (major), $-22.4,-51.9,-53.2,-55.3,-55.5,-56.5,-84.7$ ).

Catalytic Reaction of 9-Chloromethyl Anthracene with PHMe(Is) To PHMe(Is) (25 mg, 0.1 mmol) in $0.1 \mathrm{~mL}$ of toluene was added $\mathrm{NaOSiMe}_{3}(11.2 \mathrm{mg}, 0.1 \mathrm{mmol})$ suspended in $0.2 \mathrm{~mL}$ of toluene. The mixture was added to $\mathrm{Pt}(\mathrm{Me}-\mathrm{Duphos})(\mathrm{Ph})(\mathrm{PMeIs})(4.1 \mathrm{mg}, 0.005 \mathrm{mmol})$ as the catalyst precursor (5 $\mathrm{mol} \%$ ) in $0.1 \mathrm{~mL}$ of toluene and 9-chloromethyl anthracene $(22.6 \mathrm{mg}, 0.1 \mathrm{mmol})$ in $0.1 \mathrm{~mL}$ of toluene. The reaction mixture was transferred to an NMR tube, and the reaction mixture was monitored by ${ }^{31} \mathrm{P}$ NMR spectroscopy. An increasing amount of white precipitate was observed as the reaction progressed. The reaction went to completion in 1 week. The catalyst and $\mathrm{NaCl}$ were removed from the reaction mixture on a silica column (14 cm height, $1 \mathrm{~cm}$ diameter), using a 9:1 petroleum ether:THF mixture as eluent. The catalyst and $\mathrm{NaCl}$ did not elute. The solvent was removed under vacuum to give the tertiary phosphine as a yellow solid (34 mg, 77\% yield, 66\% ee). It was dissolved in $0.5 \mathrm{~mL}$ of $\mathrm{C}_{6} \mathrm{D}_{6}$ for spectroscopic characterization. 
HRMS m/z calcd. for $\mathrm{C}_{31} \mathrm{H}_{38} \mathrm{P}^{+}\left(\mathrm{MH}^{+}\right)$441.2711. Found, 441.2691. ${ }^{31} \mathrm{P}\left\{{ }^{1} \mathrm{H}\right\} \mathrm{NMR}\left(\mathrm{C}_{6} \mathrm{D}_{6}\right): \delta-36.2$ (selectivity 98\%, other peak -53.3). ${ }^{1} \mathrm{H}$ NMR $\left(\mathrm{C}_{6} \mathrm{D}_{6}\right)$ : $\delta 8.27$ (broad, 1H, Ar), 8.26 (broad, 1H, Ar), 8.12 (broad, 1H, Ar), 7.84 (broad, 1H, Ar), 7.82 (m, 1H, Ar), 7.30-7.23 (m, 4H, Ar), 7.21 (d, J = 3, 2H, Is), 4.43 $\left(\mathrm{d}, \mathrm{J}=14, \mathrm{~J}_{\mathrm{P}-\mathrm{H}}=3,1 \mathrm{H}, \mathrm{CH}_{2}\right), 4.27-4.19(\mathrm{~m}, 2 \mathrm{H}, i-\mathrm{Pr}), 4.16\left(\mathrm{~d}, \mathrm{~J}=14,1 \mathrm{H}, \mathrm{CH}_{2}\right), 2.84-2.79(\mathrm{~m}, 1 \mathrm{H}, \mathrm{CH}, i-$ $\operatorname{Pr}), 1.53\left(\mathrm{~d}, \mathrm{~J}=8,3 \mathrm{H}, \mathrm{P}-\mathrm{CH}_{3}\right), 1.34\left(\mathrm{~d}, \mathrm{~J}=7,6 \mathrm{H}, \mathrm{CH}_{3}, i\right.$-Pr), $1.27\left(\mathrm{~d}, \mathrm{~J}=7,6 \mathrm{H}, \mathrm{CH}_{3}, i\right.$-Pr), $1.26(\mathrm{~d}, \mathrm{~J}=7$, $6 \mathrm{H}, \mathrm{CH}_{3}, i$-Pr). ${ }^{13} \mathrm{C}\left\{{ }^{1} \mathrm{H}\right\} \operatorname{NMR}\left(\mathrm{C}_{6} \mathrm{D}_{6}\right): \delta 156.1$ (d, J = 14, quat, P-Is), $151.2(\mathrm{~d}, \mathrm{~J}=1$, quat), $134.2(\mathrm{~d}, \mathrm{~J}=$ 11, quat), 132.8 (d, $\mathrm{J}=28$, quat), 132.7 (d, $\mathrm{J}=3$, quat), 130.6 (d, $\mathrm{J}=5$, quat), 130.0 (Ar), 126.61-125.58 (m), 125.8 (d, J = 1, Ar), 125.79 (Ar), 125.5 (Ar), 122.9 (d, J = 4, Is), $35.1\left(\mathrm{CH}, i\right.$-Pr), 32.3 (d, J = 22, $\mathrm{CH}_{2}$ ), 29.4 (d, J = 21, CH, $i$-Pr), $25.8\left(2 \mathrm{CH}_{3}\right.$, Is $), 25.3\left(2 \mathrm{CH}_{3}, \mathrm{Is}\right), 24.5\left(2 \mathrm{CH}_{3}, \mathrm{Is}\right), 13.4$ (d, J = 23, P- $\left.\mathrm{CH}_{3}\right)$.

Reaction of Benzyl Bromide with PHMe(Phes) in the Absence of a Catalyst To PHMe(Phes) (35.2 mg, $0.1 \mathrm{mmol})$ in $0.2 \mathrm{~mL}$ of THF was added $\mathrm{NaOSiMe}_{3}(11.2 \mathrm{mg}, 0.1 \mathrm{mmol})$ suspended in $0.3 \mathrm{~mL}$ of THF. The reaction mixture was transferred to an NMR tube. Benzyl bromide (12 $\mu \mathrm{L}, 17 \mathrm{mg}, 0.1 \mathrm{mmol})$ was added via microliter syringe, and the reaction mixture was monitored by ${ }^{31} \mathrm{P}$ NMR spectroscopy. No reaction was observed after $30 \mathrm{~min}$.

Catalytic Reaction of Benzyl Bromide with PHMe(Phes) To PHMe(Phes) (35.2 mg, $0.1 \mathrm{mmol})$ in $0.1 \mathrm{~mL}$ of THF was added $\mathrm{NaOSiMe}_{3}(11.2 \mathrm{mg}, 0.1 \mathrm{mmol})$ suspended in $0.2 \mathrm{~mL}$ of THF. The mixture was added to $\mathrm{Pt}(\mathrm{Me}-\mathrm{Duphos})(\mathrm{Ph})(\mathrm{Cl})(3.1 \mathrm{mg}, 0.005 \mathrm{mmol})$ as the catalyst precursor $(5 \mathrm{~mol} \%)$ in $0.1 \mathrm{~mL}$ of THF. The reaction mixture was transferred to an NMR tube. Benzyl bromide (12 $\mu \mathrm{L}, 17 \mathrm{mg}, 0.1 \mathrm{mmol})$ was added via microliter syringe, and the reaction mixture was monitored by ${ }^{31} \mathrm{P}$ NMR spectroscopy. An increasing amount of white precipitate was observed as the reaction progressed. The reaction went to completion in $\sim 30 \mathrm{~min}$. The catalyst and $\mathrm{NaBr}$ were removed from the reaction mixture on a silica column ( $5 \mathrm{~cm}$ height, $0.6 \mathrm{~cm}$ diameter), using a 9:1 petroleum ether:THF mixture as eluent. The catalyst and $\mathrm{NaBr}$ did not elute. The solvent was removed under vacuum and $38 \mathrm{mg}$ ( $86 \%$ yield) of colorless liquid (81\% ee) was obtained. The tertiary phosphine was dissolved in $0.5 \mathrm{~mL}$ of $\mathrm{C}_{6} \mathrm{D}_{6}$ for spectroscopic characterization.

HRMS m/z calcd. for $\mathrm{C}_{32} \mathrm{H}_{28} \mathrm{PO}^{+}\left(\mathrm{MOH}^{+}\right)$459.1878. Found, 459.1860. ${ }^{31} \mathrm{P}\left\{{ }^{1} \mathrm{H}\right\} \mathrm{NMR}\left(\mathrm{C}_{6} \mathrm{D}_{6}\right): \delta$ -22.2 (selectivity 100\%). ${ }^{1} \mathrm{H}$ NMR $\left(\mathrm{C}_{6} \mathrm{D}_{6}\right): \delta 7.50(\mathrm{~d}, \mathrm{~J}=2,2 \mathrm{H}, \mathrm{Ar}), 7.41-7.38(\mathrm{~m}, 5 \mathrm{H}, \mathrm{Ar}), 7.20-7.10$ (m, 10H, Ar), 6.99-6.96 (m, 2H, Ar), $6.92(\mathrm{~d}, \mathrm{~J}=8,1 \mathrm{H}, \operatorname{Ar}), 6.82(\mathrm{~d}, \mathrm{~J}=8,2 \mathrm{H}, \operatorname{Ar}), 2.92\left(\mathrm{dd}, \mathrm{J}=13, \mathrm{~J}_{\mathrm{PH}}=4\right.$, $\left.1 \mathrm{H}, \mathrm{CH}_{2}\right), 2.56\left(\mathrm{dd}, \mathrm{J}=13, \mathrm{~J}_{\mathrm{PH}}=2,1 \mathrm{H}, \mathrm{CH}_{2}\right), 0.66\left(\mathrm{~d}, \mathrm{~J}_{\mathrm{PH}}=6,3 \mathrm{H}, \mathrm{P}-\mathrm{CH}_{3}\right) \cdot{ }^{13} \mathrm{C}\left\{{ }^{1} \mathrm{H}\right\} \mathrm{NMR}\left(\mathrm{C}_{6} \mathrm{D}_{6}\right): \delta$ $150.1(\mathrm{~d}, \mathrm{~J}=14$, quat), $144.3(\mathrm{~d}, \mathrm{~J}=4$, quat), 140.8, 140.6, $139.4(\mathrm{~d}, \mathrm{~J}=8), 135.9(\mathrm{~d}, \mathrm{~J}=35), 130.7(\mathrm{~d}, \mathrm{~J}=$ 
3, Ar), 130.3, 129.9 (d, J = 6, Ar), 129.47, 129.35 (d, J = 1, Ar), 128.8 (d, J = 1), 128.7 (d, J = 3), 128.4, $127.8(\mathrm{~d}, \mathrm{~J}=5), 126.2(\mathrm{~d}, \mathrm{~J}=3, \mathrm{Ar}), 37.8\left(\mathrm{~d}, \mathrm{~J}=19, \mathrm{CH}_{2}\right), 11.6\left(\mathrm{~d}, \mathrm{~J}=20, \mathrm{P}-\mathrm{CH}_{3}\right)$.

Reaction of Benzyl Bromide with PHMe(Mes) in the Absence of a Catalyst To PHMe(Mes) (17 $\mathrm{mg}, 0.1 \mathrm{mmol})$ in $0.2 \mathrm{~mL}$ of THF was added $\mathrm{NaOSiMe}_{3}(11.2 \mathrm{mg}, 0.1 \mathrm{mmol})$ suspended in $0.3 \mathrm{~mL}$ of THF. The reaction mixture was transferred to an NMR tube. Benzyl bromide (12 $\mu \mathrm{L}, 17 \mathrm{mg}, 0.1 \mathrm{mmol})$ was added via microliter syringe, and the reaction mixture was monitored by ${ }^{31} \mathrm{P}$ NMR spectroscopy. No reaction was observed after $30 \mathrm{~min}$.

Catalytic Reaction of Benzyl Bromide with PHMe(Mes) To PHMe(Mes) (17 mg, $0.1 \mathrm{mmol})$ in $0.1 \mathrm{~mL}$ of THF was added $\mathrm{NaOSiMe}_{3}(11.2 \mathrm{mg}, 0.1 \mathrm{mmol})$ suspended in $0.2 \mathrm{~mL}$ of THF. The mixture was added to $\mathrm{Pt}(\mathrm{Me}-\mathrm{Duphos})(\mathrm{Ph})(\mathrm{Cl})(3.1 \mathrm{mg}, 0.005 \mathrm{mmol})$ as the catalyst precursor $(5 \mathrm{~mol} \%)$ in $0.1 \mathrm{~mL}$ of THF. The reaction mixture was transferred to an NMR tube. Benzyl bromide (12 $\mu \mathrm{L}, 17 \mathrm{mg}, 0.1 \mathrm{mmol})$ was added via microliter syringe, and the reaction mixture was monitored by ${ }^{31} \mathrm{P}$ NMR spectroscopy. An increasing amount of white precipitate was observed as the reaction progressed. The reaction went to completion in $\sim 30 \mathrm{~min}$. The catalyst and $\mathrm{NaBr}$ were removed from the reaction mixture on a silica column ( $5 \mathrm{~cm}$ height, $0.6 \mathrm{~cm}$ diameter), using a 9:1 petroleum ether:THF mixture as eluent. The catalyst and $\mathrm{NaBr}$ did not elute. The solvent was removed under vacuum and $22 \mathrm{mg}$ (86\% yield) of colorless liquid (69\% ee) was obtained. The tertiary phosphine was dissolved in $0.5 \mathrm{~mL}$ of $\mathrm{C}_{6} \mathrm{D}_{6}$ for spectroscopic characterization.

HRMS m/z calcd. for $\mathrm{C}_{17} \mathrm{H}_{22} \mathrm{P}^{+}\left(\mathrm{MH}^{+}\right)$257.1459. Found, 257.1441. ${ }^{31} \mathrm{P}\left\{{ }^{1} \mathrm{H}\right\} \mathrm{NMR}\left(\mathrm{C}_{6} \mathrm{D}_{6}\right): \delta-33.5$ (selectivity 98\%; other peaks $\delta 28.5,-14.0) .{ }^{1} \mathrm{H}$ NMR $\left(\mathrm{C}_{6} \mathrm{D}_{6}\right): \delta 7.10-6.98(\mathrm{~m}, 5 \mathrm{H}, \mathrm{Ar}), 6.71$ (broad, $2 \mathrm{H}$, $\operatorname{Ar}), 3.12\left(\mathrm{dd}, \mathrm{J}=13, \mathrm{~J}_{\mathrm{PH}}=1,1 \mathrm{H}, \mathrm{CH}_{2}\right), 3.02\left(\mathrm{dd}, \mathrm{J}=13, \mathrm{~J}_{\mathrm{PH}}=3,1 \mathrm{H}, \mathrm{CH}_{2}\right), 2.44\left(6 \mathrm{H}, \mathrm{CH}_{3}\right), 2.07(3 \mathrm{H}$, $\left.\mathrm{CH}_{3}\right), 1.30\left(\mathrm{~d}, \mathrm{~J}_{\mathrm{PH}}=6,3 \mathrm{H}, \mathrm{P}-\mathrm{CH}_{3}\right) .{ }^{13} \mathrm{C}\left\{{ }^{1} \mathrm{H}\right\} \mathrm{NMR}\left(\mathrm{C}_{6} \mathrm{D}_{6}\right): \delta 144.9(\mathrm{~d}, \mathrm{~J}=15$, quat $), 139.9(\mathrm{~d}, \mathrm{~J}=8$, quat$)$, 139.1 (d, J = 1, quat), 131.5 (d, J = 26, Ar), 130.5 (d, J = 4, Ar), 129.7 (d, J = 6, Ar), 128.8 (d, J = 2, Ar), $126.2(\mathrm{~d}, \mathrm{~J}=3, \mathrm{Ar}), 35.7\left(\mathrm{~d}, \mathrm{~J}=17, \mathrm{CH}_{2}\right), 23.8\left(\mathrm{~d}, \mathrm{~J}=19,2 \mathrm{CH}_{3}\right), 21.3\left(\mathrm{CH}_{3}\right), 10.9\left(\mathrm{~d}, \mathrm{~J}=19, \mathrm{P}-\mathrm{CH}_{3}\right)$.

\section{Reaction of Benzyl Bromide with PHMe(Ph) in the Absence of a Catalyst To $\mathrm{PHMe}(\mathrm{Ph})(12.4$} $\mathrm{mg}, 0.1 \mathrm{mmol})$ in $0.2 \mathrm{~mL}$ of THF was added $\mathrm{NaOSiMe}_{3}(11.2 \mathrm{mg}, 0.1 \mathrm{mmol})$ suspended in $0.3 \mathrm{~mL}$ of THF. The reaction mixture was transferred to an NMR tube. Benzyl bromide (12 $\mu \mathrm{L}, 17 \mathrm{mg}, 0.1 \mathrm{mmol})$ was added via microliter syringe, and the reaction mixture was monitored by ${ }^{31} \mathrm{P}$ NMR spectroscopy. Formation of a white precipitate was observed as the reaction progressed. After $1 \mathrm{~d}$ the conversion was $97 \%$ and the selectivity $60 \%$ (other peaks $\delta 27.4,-39.7,-43.2$ ). 
Catalytic Reaction of Benzyl Bromide with PHMe(Ph) To PHMe(Ph) (12.4 mg, $0.1 \mathrm{mmol})$ in 0.2 $\mathrm{mL}$ of THF was added $\mathrm{NaOSiMe}_{3}(11.2 \mathrm{mg}, 0.1 \mathrm{mmol})$ suspended in $0.2 \mathrm{~mL}$ of THF. The mixture was added to $\mathrm{Pt}(\mathrm{Me}-\mathrm{Duphos})(\mathrm{Ph})(\mathrm{Cl})(3.1 \mathrm{mg}, 0.005 \mathrm{mmol})$ as the catalyst precursor $(5 \mathrm{~mol} \%)$ in $0.1 \mathrm{~mL}$ of THF. The reaction mixture was transferred to an NMR tube. Benzyl bromide (12 $\mu \mathrm{L}, 17 \mathrm{mg}, 0.1 \mathrm{mmol})$ was added via microliter syringe, and the reaction mixture was monitored by ${ }^{31} \mathrm{P}$ NMR spectroscopy. An increasing amount of white precipitate was observed as the reaction progressed. The reaction went to completion in less than $30 \mathrm{~min}$. The catalyst and $\mathrm{NaBr}$ were removed from the reaction mixture on a silica column (14 cm height, $1 \mathrm{~cm}$ diameter), using a 9:1 petroleum ether:THF mixture as eluent. The catalyst and $\mathrm{NaBr}$ did not elute. The solvent was removed under vacuum and $18 \mathrm{mg}$ (84\% yield) of a colorless oil (35\% ee) was obtained. The tertiary phosphine was dissolved in $0.5 \mathrm{~mL}$ of $\mathrm{C}_{6} \mathrm{D}_{6}$ for spectroscopic characterization.

${ }^{31} \mathrm{P}\left\{{ }^{1} \mathrm{H}\right\}$ NMR $\left(\mathrm{C}_{6} \mathrm{D}_{6}\right): \delta-29.1 .{ }^{13} \mathrm{C}\left\{{ }^{1} \mathrm{H}\right\} \operatorname{NMR}\left(\mathrm{C}_{6} \mathrm{D}_{6}\right): \delta 140.8(\mathrm{~d}, \mathrm{~J}=17$, quat Ar), $138.4(\mathrm{~d}, \mathrm{~J}=5$, quat Ar), 132.3 (d, J = 18, Ar), 129.8 (d, J = 5, Ar), 128.9 (d, J = 15, Ar), 128.82 (Ar), 128.81 (Ar), 126.3 $(\mathrm{d}, \mathrm{J}=2), 39.0\left(\mathrm{~d}, \mathrm{~J}=17, \mathrm{CH}_{2}\right), 10.8(\mathrm{~d}, \mathrm{~J}=17, \mathrm{P}-\mathrm{Me}) .{ }^{1} \mathrm{H}$ NMR $\left(\mathrm{C}_{6} \mathrm{D}_{6}\right): \delta$ 7.34-7.30 (m, 2H, Ar), 7.13$7.06(\mathrm{~m}, 5 \mathrm{H}, \mathrm{Ar}), 7.02-6.99$ (m, 1H, Ar), 6.96-6.94 (m, 2H, Ar), $2.89\left(\mathrm{dd}, \mathrm{J}=13,3,1 \mathrm{H}, \mathrm{CH}_{2}\right), 2.72(\mathrm{~d}, \mathrm{~J}=$ 13, $\left.1 \mathrm{H}, \mathrm{CH}_{2}\right), 1.02(\mathrm{~d}, \mathrm{~J}=4, \mathrm{Me})$. These NMR data were consistent with the literature reports for this phosphine. ${ }^{15}$

Reaction of Benzyl Bromide with PHMe(Men) in the Absence of a Catalyst To PHMe(Men) (9.3 $\mathrm{mg}, 0.05 \mathrm{mmol})$ in $0.2 \mathrm{~mL}$ of THF was added $\mathrm{NaOSiMe}_{3}(5.6 \mathrm{mg}, 0.05 \mathrm{mmol})$ suspended in $0.3 \mathrm{~mL}$ of THF. The reaction mixture was transferred to an NMR tube. Benzyl bromide ( $6 \mu \mathrm{L}, 17 \mathrm{mg}, 0.05 \mathrm{mmol})$ was added via microliter syringe, and the reaction mixture was monitored by ${ }^{31} \mathrm{P}$ NMR spectroscopy. Formation of a white precipitate was observed as the reaction progressed. After $30 \mathrm{~min}$ the conversion was $8 \%$.

Catalytic Reaction of Benzyl Bromide with PHMe(Men) To PHMe(Men) (18.6 mg, $0.1 \mathrm{mmol})$ in $0.1 \mathrm{~mL}$ of THF was added $\mathrm{NaOSiMe}_{3}(11.2 \mathrm{mg}, 0.1 \mathrm{mmol})$ suspended in $0.2 \mathrm{~mL}$ of THF. The mixture was added to $\mathrm{Pt}(\mathrm{Me}-\mathrm{Duphos})(\mathrm{Ph})(\mathrm{Cl})(3.1 \mathrm{mg}, 0.005 \mathrm{mmol})$ as the catalyst precursor $(5 \mathrm{~mol} \%)$ in $0.1 \mathrm{~mL}$ of THF. The reaction mixture was transferred to an NMR tube. Benzyl bromide (12 $\mu \mathrm{L}, 17 \mathrm{mg}, 0.1 \mathrm{mmol})$ was added via microliter syringe, and the reaction mixture was monitored by ${ }^{31} \mathrm{P}$ NMR spectroscopy. An increasing amount of white precipitate was observed as the reaction progressed. The reaction went to 
completion in $\sim 10 \mathrm{~min}$. The catalyst and $\mathrm{NaBr}$ were removed from the reaction mixture on a silica column ( $5 \mathrm{~cm}$ height, $0.6 \mathrm{~cm}$ diameter), using a 9:1 petroleum ether:THF mixture as eluent. The catalyst and $\mathrm{NaBr}$ did not elute. The solvent was removed under vacuum and $24 \mathrm{mg}$ ( $87 \%$ yield) of colorless liquid (56\% de) was obtained. The tertiary phosphine was dissolved in $0.5 \mathrm{~mL}$ of $\mathrm{C}_{6} \mathrm{D}_{6}$ for spectroscopic characterization.

HRMS m/z calcd. for $\mathrm{C}_{18} \mathrm{H}_{30} \mathrm{PO}^{+}\left(\mathrm{MOH}^{+}\right)$293.2034. Found, 293.2022. The following NMR spectra are reported as a mixture of two diastereomers a and $\mathrm{b}(\mathrm{a}: \mathrm{b}=3.5: 1,56 \%$ de $)$ unless otherwise indicated.

${ }^{31} \mathrm{P}\left\{{ }^{1} \mathrm{H}\right\}$ NMR $\left(\mathrm{C}_{6} \mathrm{D}_{6}\right): \delta-30.7(\mathrm{~b}),-31.0$ (a) (selectivity $\left.100 \%\right) .{ }^{1} \mathrm{H}$ NMR $\left(\mathrm{C}_{6} \mathrm{D}_{6}\right): \delta 7.23-7.19$ (broad $\mathrm{m}, 2 \mathrm{H}, \mathrm{Ar}), 7.16-7.11(\mathrm{~m}, 2 \mathrm{H}, \mathrm{Ar}), 7.05-7.00(\operatorname{broad} \mathrm{m}, 1 \mathrm{H}, \mathrm{Ar}), 2.73\left(\mathrm{dd}, \mathrm{J}=13, \mathrm{~J}_{\mathrm{PH}}=3,1 \mathrm{H}, \mathrm{CH}_{2}, \mathrm{a}\right)$, 2.72-2.66 (m, 1H, CH), $2.64\left(\mathrm{~d}, \mathrm{~J}=13,1 \mathrm{H}, \mathrm{CH}_{2}, \mathrm{~b}\right), 2.57\left(\mathrm{~d}, \mathrm{~J}=13,1 \mathrm{H}, \mathrm{CH}_{2}, \mathrm{~b}\right), 2.41\left(\mathrm{dd}, \mathrm{J}=13, \mathrm{~J}_{\mathrm{PH}}=3\right.$, $\left.1 \mathrm{H}, \mathrm{CH}_{2}, \mathrm{a}\right), 1.80-1.76(\mathrm{~m}, 1 \mathrm{H}, \mathrm{CH}, \mathrm{a}), 1.75-1.71$ (m, 1H, CH, b), 1.69-1.64 (m, 1H, CH), 1.64-1.59 (m, $1 \mathrm{H}, \mathrm{CH}), 1.27-1.21\left(\mathrm{~m}, 1 \mathrm{H}, \mathrm{CH}_{2}\right), 1.19-1.10\left(\mathrm{~m}, 1 \mathrm{H}, \mathrm{CH}_{2}\right), 1.09-1.02\left(\mathrm{~m}, 1 \mathrm{H}, \mathrm{CH}_{2}\right), 1.01-0.93(\mathrm{~m}, 1 \mathrm{H}$, $\left.\mathrm{CH}_{2}\right), 0.92\left(\mathrm{~d}, \mathrm{~J}=7,3 \mathrm{H}, \mathrm{CH}_{3}, \mathrm{a}\right), 0.91\left(\mathrm{~d}, \mathrm{~J}=7,3 \mathrm{H}, \mathrm{CH}_{3}, \mathrm{~b}\right), 0.88\left(\mathrm{~d}, \mathrm{~J}=8,1 \mathrm{H}, \mathrm{CH}_{2}\right), 0.85\left(\mathrm{dd}, \mathrm{J}=7, \mathrm{~J}_{\mathrm{PH}}=\right.$ $\left.1,3 \mathrm{H}, \mathrm{CH}_{3}\right), 0.84\left(\mathrm{dd}, \mathrm{J}=7, \mathrm{~J}_{\mathrm{PH}}=1,3 \mathrm{H}, \mathrm{CH}_{3}\right), 0.80\left(\mathrm{~d}, \mathrm{~J}_{\mathrm{PH}}=5,3 \mathrm{H}, \mathrm{P}-\mathrm{CH}_{3}\right) \cdot{ }^{13} \mathrm{C}\left\{{ }^{1} \mathrm{H}\right\} \mathrm{NMR}\left(\mathrm{C}_{6} \mathrm{D}_{6}\right): \delta$ 140.1 (d, J = 8, quat), 129.96 (d, J = 6, Ar, a), 129.85 (d, J = 6, Ar, b), 128.99 (d, J = 1, Ar, b), 128.96 (d, J $=1, \operatorname{Ar}, a), 126.3(d, J=2, A r, b), 126.2(d, J=2, A r, a), 45.8(d, J=9, C H, a), 45.6(d, J=11, C H, b), 39.6$ $\left(\mathrm{CH}_{2}, \mathrm{a}\right), 39.4\left(\mathrm{CH}_{2}, \mathrm{~b}\right), 35.9(\mathrm{CH}, \mathrm{a}), 35.8(\mathrm{CH}, \mathrm{b}), 35.10\left(\mathrm{~d}, \mathrm{~J}=4, \mathrm{CH}_{2}, \mathrm{a}\right), 35.05\left(\mathrm{~d}, \mathrm{~J} \sim 5, \mathrm{CH}_{2}, \mathrm{~b}\right.$, overlapping the 35.10 peak), $34.3(\mathrm{~d}, \mathrm{~J}=1, \mathrm{CH}, \mathrm{a}), 34.1(\mathrm{CH}, \mathrm{b}), 31.9\left(\mathrm{~d}, \mathrm{~J}=20, \mathrm{P}_{-} \mathrm{CH}_{2}\right), 28.25(\mathrm{~d}, \mathrm{~J}=21$, $\mathrm{CH}, \mathrm{a}), 28.14$ (d, J = 22, CH, b), 26.2 (d, J = 6, $\left.\mathrm{CH}_{2}, \mathrm{a}\right), 26.1$ (d, J = 7, $\left.\mathrm{CH}_{2}, \mathrm{~b}\right), 23.32\left(\mathrm{CH}_{3}, i-\mathrm{Pr}, \mathrm{b}\right), 23.28$ $\left(\mathrm{CH}_{3}, i\right.$-Pr, a), $22.12\left(\mathrm{CH}_{3}, i-\mathrm{Pr}, \mathrm{b}\right), 22.05\left(\mathrm{CH}_{3}, i-\mathrm{Pr}, \mathrm{a}\right), 15.8\left(\mathrm{~d}, \mathrm{~J}=2, \mathrm{CH}_{3}, \mathrm{a}\right), 15.7\left(\mathrm{~d}, \mathrm{~J}=2, \mathrm{CH}_{3}, \mathrm{~b}\right), 9.1$ $\left(\mathrm{d}, \mathrm{J}=20, \mathrm{P}-\mathrm{CH}_{3}, \mathrm{a}\right), 5.5\left(\mathrm{~d}, \mathrm{~J}=23, \mathrm{P}-\mathrm{CH}_{3}, \mathrm{~b}\right)$.

\section{Reaction of Benzyl Bromide with PHPh(Cy) in the Absence of a Catalyst To $\mathrm{PHPh}(\mathrm{Cy})(19 \mathrm{mg}$,} $0.1 \mathrm{mmol})$ in $0.2 \mathrm{~mL}$ of THF was added $\mathrm{NaOSiMe}_{3}(11.2 \mathrm{mg}, 0.1 \mathrm{mmol})$ suspended in $0.3 \mathrm{~mL}$ of THF. The reaction mixture was transferred to an NMR tube. Benzyl bromide (12 $\mu \mathrm{L}, 17 \mathrm{mg}, 0.1 \mathrm{mmol}$ ) was added via microliter syringe, and the reaction mixture was monitored by ${ }^{31} \mathrm{P}$ NMR spectroscopy. Formation of a white precipitate was observed as the reaction progressed. After $2 \mathrm{~d}$ the conversion was $45 \%$ and the selectivity $65 \%$ (in addition to $\mathrm{PPh}(\mathrm{Cy})\left(\mathrm{CH}_{2} \mathrm{Ph}\right.$ ), another peak at $34 \mathrm{ppm}$ was observed).

Catalytic Reaction of Benzyl Bromide with PHPh(Cy) To $\mathrm{PHPh}(\mathrm{Cy})(19 \mathrm{mg}, 0.1 \mathrm{mmol})$ in $0.2 \mathrm{~mL}$ of THF was added $\mathrm{NaOSiMe}_{3}(11.2 \mathrm{mg}, 0.1 \mathrm{mmol})$ suspended in $0.2 \mathrm{~mL}$ of THF. The mixture was added to $\mathrm{M}(\mathrm{Me}-\mathrm{Duphos})(\mathrm{Y})(\mathrm{Z})(0.005 \mathrm{mmol}$; Table 3$)$ as the catalyst precursor $(5 \mathrm{~mol} \%)$ in $0.1 \mathrm{~mL}$ of $\mathrm{THF}$. 
The reaction mixture was transferred to an NMR tube. Benzyl bromide (12 $\mu \mathrm{L}, 17 \mathrm{mg}, 0.1 \mathrm{mmol})$ was added via microliter syringe, and the reaction mixture was monitored by ${ }^{31} \mathrm{P}$ NMR spectroscopy. An increasing amount of white precipitate was observed as the reaction progressed. The catalyst and $\mathrm{NaBr}$ were removed from the reaction mixture on a silica column (14 cm height, $1 \mathrm{~cm}$ diameter), using a 9:1 petroleum ether:THF mixture as eluent. The catalyst and $\mathrm{NaBr}$ did not elute. The solvent was removed under vacuum and the tertiary phosphine was dissolved in $0.5 \mathrm{~mL}$ of $\mathrm{C}_{6} \mathrm{D}_{6}$ for spectroscopic characterization.

Table 3. Catalytic asymmetric benzylation of $\mathrm{PHPh}(\mathrm{Cy})$

\begin{tabular}{|l|l|l|l|l|l|}
\hline Catalyst precursor & Mass (mg) & Time & Selectivity (\%) & Yield (\%) & ee (\%) \\
\hline $\operatorname{Pt}($ Me-Duphos $)(\mathrm{Ph})(\mathrm{Cl})$ & 3.1 & 1 hour & $\begin{array}{l}99, \text { other peaks } \\
\delta-12.1,53.9\end{array}$ & 93 & 48 \\
\hline $\operatorname{Pd}(\mathrm{Me}-$ Duphos $)\left(\mathrm{C}_{6} \mathrm{~F}_{5}\right)(\mathrm{I})$ & 3.5 & $1 \mathrm{~d}$ & $\begin{array}{l}49, \text { other peaks } \\
\delta-14.9,-23.3\end{array}$ & 90 & -18 \\
\hline
\end{tabular}

The phosphine $\mathrm{PPh}(\mathrm{Cy})\left(\mathrm{CH}_{2} \mathrm{Ph}\right)$ is a known compound and ${ }^{31} \mathrm{P}\left(\delta-4.2\left(\mathrm{C}_{6} \mathrm{D}_{6}\right.\right.$, lit. $\left.-6.1\left(\mathrm{CDCl}_{3}\right)\right)$, ${ }^{1} \mathrm{H}$, and ${ }^{13} \mathrm{C}$ NMR data were consistent with those reported in a different solvent. ${ }^{16}$ The ee was determined by the general method: ${ }^{31} \mathrm{P}\left\{{ }^{1} \mathrm{H}\right\}$ NMR $\left(\mathrm{C}_{6} \mathrm{D}_{6}\right): \delta 51.1,46.6$, (48\% ee). The solvent was removed from this sample under vacuum, and the residue was redissolved in $\mathrm{CDCl}_{3}$ for direct comparison to the literature ${ }^{31} \mathrm{P}$ NMR chemical shifts: $\delta 47.3\left(R_{C}, S_{P}\right), 43.3\left(R_{C}, R_{P}\right)$. The major diastereomer produced here showed the $47.3 \mathrm{ppm}$ shift, but since the $\mathrm{S}_{\mathrm{C}}$-form of the Pd reagent was used, this corresponds to the $S_{C}, R_{P}$ diastereomer, and the major enantiomer of the phosphine formed in this catalytic reaction is $R_{\mathrm{P}}$. Note that the $\mathrm{S}_{\mathrm{P}}$-enantiomer was favored with the Pd catalyst.

Reaction of Benzyl Bromide with PHPh(t-Bu) in the Absence of a Catalyst To $\mathrm{PHPh}(\mathrm{t}-\mathrm{Bu})(16.6$ $\mathrm{mg}, 0.1 \mathrm{mmol})$ in $0.2 \mathrm{~mL}$ of THF was added $\mathrm{NaOSiMe}_{3}(11.2 \mathrm{mg}, 0.1 \mathrm{mmol})$ suspended in $0.3 \mathrm{~mL}$ of THF. The reaction mixture was transferred to an NMR tube. Benzyl bromide (12 $\mu \mathrm{L}, 17 \mathrm{mg}, 0.1 \mathrm{mmol})$ was added via microliter syringe, and the reaction mixture was monitored by ${ }^{31} \mathrm{P}$ NMR spectroscopy. Formation of a white precipitate was observed as the reaction progressed. After $1 \mathrm{~d}$ the conversion was $4 \%$.

Catalytic Reaction of Benzyl Bromide with PHPh(t-Bu) To PHPh(t-Bu) (16.6 mg, $0.1 \mathrm{mmol})$ in $0.1 \mathrm{~mL}$ of THF was added $\mathrm{NaOSiMe}_{3}(11.2 \mathrm{mg}, 0.1 \mathrm{mmol})$ suspended in $0.2 \mathrm{~mL}$ of THF. The mixture 
was added to $\mathrm{Pt}(\mathrm{Me}-\mathrm{Duphos})(\mathrm{Ph})(\mathrm{Cl})(3.1 \mathrm{mg}, 0.005 \mathrm{mmol})$ as the catalyst precursor $(5 \mathrm{~mol} \%)$ in $0.1 \mathrm{~mL}$ of THF. The reaction mixture was transferred to an NMR tube. Benzyl bromide (12 $\mu \mathrm{L}, 17 \mathrm{mg}, 0.1 \mathrm{mmol})$ was added via microliter syringe, and the reaction mixture was monitored by ${ }^{31} \mathrm{P}$ NMR spectroscopy. An increasing amount of white precipitate was observed as the reaction progressed. The reaction went to completion in less than $1 \mathrm{~d}$. The catalyst and $\mathrm{NaBr}$ were removed from the reaction mixture on a silica column (5 cm height, $0.6 \mathrm{~cm}$ diameter), using a 9:1 petroleum ether:THF mixture as eluent. The catalyst and $\mathrm{NaBr}$ did not elute. The solvent was removed under vacuum and $23 \mathrm{mg}$ (90\% yield) of colorless liquid was obtained $\left(42 \%\right.$ ee). The tertiary phosphine was dissolved in $0.5 \mathrm{~mL}$ of $\mathrm{C}_{6} \mathrm{D}_{6}$ for spectroscopic characterization.

HRMS m/z calcd. for $\mathrm{C}_{17} \mathrm{H}_{22} \mathrm{P}^{+}\left(\mathrm{MH}^{+}\right)$257.1459. Found, 257.1454. ${ }^{31} \mathrm{P}\left\{{ }^{1} \mathrm{H}\right\} \mathrm{NMR}\left(\mathrm{C}_{6} \mathrm{D}_{6}\right): \delta 10.7$ (selectivity 100\%). ${ }^{1} \mathrm{H}$ NMR $\left(\mathrm{C}_{6} \mathrm{D}_{6}\right): \delta$ 7.52-7.48 (m, 2H, Ar), 7.28 (broad d, J = 8, 2H, Ar), 7.15-7.04 (m, 4H, Ar), 7.02-6.97 (m, 1H, Ar), 6.95-6.92 (m, 1H, Ar), 3.16 (dd, J = 14, J $\left.\mathrm{PH}_{1}=3,1 \mathrm{H}, \mathrm{CH}_{2}\right), 2.96(\mathrm{dd}, \mathrm{J}=14$,

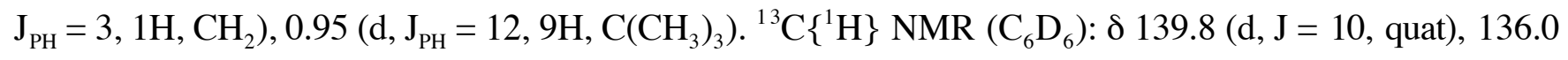
(d, J = 23, quat), 135.2 (d, J = 20, Ar), 130.2 (d, J = 7, Ar), 129.5 (d, J = 1, Ar), 128.9 (d, J = 1, Ar), 128.3 $(\mathrm{d}, \mathrm{J}=10, \operatorname{Ar}), 126.3$ (d, J = 2, Ar), $29.8\left(\mathrm{~d}, \mathrm{~J}=15, \mathrm{P}-\mathrm{CMe}_{3}\right), 29.4\left(\mathrm{~d}, \mathrm{~J}=20, \mathrm{CH}_{2}\right), 27.9\left(\mathrm{~d}, \mathrm{~J}=14, \mathrm{CH}_{3}\right)$.

Reaction of Benzyl Bromide with $\operatorname{PHPh}(o-A n)$ in the Absence of a Catalyst To $\operatorname{PHPh}(o-\mathrm{An})$ $(21.6 \mathrm{mg}, 0.1 \mathrm{mmol})$ in $0.2 \mathrm{~mL}$ of THF was added $\mathrm{NaOSiMe}_{3}(11.2 \mathrm{mg}, 0.1 \mathrm{mmol})$ suspended in $0.3 \mathrm{~mL}$ of THF. The reaction mixture was transferred to an NMR tube. Benzyl bromide (12 $\mu \mathrm{L}, 17 \mathrm{mg}, 0.1 \mathrm{mmol})$ was added via microliter syringe, and the reaction mixture was monitored by ${ }^{31} \mathrm{P}$ NMR spectroscopy. Formation of a white precipitate was observed as the reaction progressed. After $30 \mathrm{~min}$ the conversion was $24 \%$ and the selectivity $69 \%$ (other peaks at $\delta 22.4$ and 7.8 were also observed).

Catalytic Reaction of Benzyl Bromide with PHPh(o-An) To PHPh(o-An) (21.6 mg, $0.1 \mathrm{mmol})$ in $0.1 \mathrm{~mL}$ of THF was added $\mathrm{NaOSiMe}_{3}(11.2 \mathrm{mg}, 0.1 \mathrm{mmol})$ suspended in $0.2 \mathrm{~mL}$ of THF. The mixture was added to $\mathrm{Pt}(\mathrm{Me}-\mathrm{Duphos})(\mathrm{Ph})(\mathrm{Cl})(3.1 \mathrm{mg}, 0.005 \mathrm{mmol})$ as the catalyst precursor $(5 \mathrm{~mol} \%)$ in $0.1 \mathrm{~mL}$ of THF. The reaction mixture was transferred to an NMR tube. Benzyl bromide (12 $\mu \mathrm{L}, 17 \mathrm{mg}, 0.1 \mathrm{mmol})$ was added via microliter syringe, and the reaction mixture was monitored by ${ }^{31} \mathrm{P}$ NMR spectroscopy. An increasing amount of white precipitate was observed as the reaction progressed. The reaction went to completion in $\sim 15 \mathrm{~min}$. The catalyst and $\mathrm{NaBr}$ were removed from the reaction mixture on a silica column (5 cm height, $0.6 \mathrm{~cm}$ diameter), using a 9:1 petroleum ether:THF mixture as eluent. The catalyst and $\mathrm{NaBr}$ 
did not elute. The solvent was removed under vacuum and $26 \mathrm{mg}$ (85\% yield) of colorless liquid (9\% ee) was obtained. The tertiary phosphine was dissolved in $0.5 \mathrm{~mL}$ of $\mathrm{C}_{6} \mathrm{D}_{6}$ for spectroscopic characterization.

HRMS m/z calcd. for $\mathrm{C}_{20} \mathrm{H}_{20} \mathrm{OP}^{+}\left(\mathrm{MH}^{+}\right)$307.1252. Found, 307.1244. The protonated phosphine oxide was also observed: $\mathrm{m} / \mathrm{z}$ calcd. for $\mathrm{C}_{20} \mathrm{H}_{20} \mathrm{O}_{2} \mathrm{P}^{+}\left(\mathrm{M}(\mathrm{O}) \mathrm{H}^{+}\right)$323.1201. Found, 323.1194. ${ }^{31} \mathrm{P}\left\{{ }^{1} \mathrm{H}\right\} \mathrm{NMR}$ $\left(\mathrm{C}_{6} \mathrm{D}_{6}\right): \delta$-17.7 (selectivity 97\%, other peak -17.3). ${ }^{1} \mathrm{H}$ NMR $\left(\mathrm{C}_{6} \mathrm{D}_{6}\right): \delta$ 7.55-7.52 (m, 2H, Ar), 7.38 (ddd, $\mathrm{J}=8,2, \mathrm{~J}_{\mathrm{PH}}=5,1 \mathrm{H}$, Ar), 7.25 (broad, 1H, Ar), 7.24 (broad, 1H, Ar), 7.20 (ddd, $\mathrm{J}=9,8,1,1 \mathrm{H}$, Ar), 7.16$7.12(\mathrm{~m}, 5 \mathrm{H}, \mathrm{Ar}), 7.07-7.04(\mathrm{~m}, 1 \mathrm{H}, \mathrm{Ar}), 6.91\left(\mathrm{dtd}, \mathrm{J}=8,1, \mathrm{~J}_{\mathrm{PH}}=1,1 \mathrm{H}, \mathrm{Ar}\right), 6.54\left(\mathrm{ddd}, \mathrm{J}=9,1, \mathrm{~J}_{\mathrm{PH}}=4\right.$, $1 \mathrm{H}, \mathrm{Ar}), 3.64\left(\mathrm{dd}, \mathrm{J}=14, \mathrm{~J}_{\mathrm{PH}}=1,1 \mathrm{H}, \mathrm{CH}_{2}\right), 3.35\left(\mathrm{dd}, \mathrm{J}=14,1 \mathrm{H}, \mathrm{CH}_{2}\right), 3.23\left(3 \mathrm{H}, \mathrm{OCH}_{3}\right) .{ }^{13} \mathrm{C}\left\{{ }^{1} \mathrm{H}\right\} \mathrm{NMR}$ $\left(\mathrm{C}_{6} \mathrm{D}_{6}\right): \delta 162.0(\mathrm{~d}, \mathrm{~J}=12$, quat), 139.1 (d, $\mathrm{J}=9$, quat), 138.9 (d, $\mathrm{J}=17$, quat), 134.1 (d, $\mathrm{J}=20$, Ar), 133.4 $(\mathrm{d}, \mathrm{J}=7, \operatorname{Ar}), 130.6,130.2,130.1,129.0,128.8(\mathrm{~d}, \mathrm{~J}=2, \operatorname{Ar}), 128.7(\mathrm{~d}, \mathrm{~J}=7, \operatorname{Ar}), 126.3(\mathrm{~d}, \mathrm{~J}=3, \operatorname{Ar})$, $121.5(\mathrm{~d}, \mathrm{~J}=2, \mathrm{Ar}), 111.0(\mathrm{~d}, \mathrm{~J}=1, \mathrm{Ar}), 55.4\left(\mathrm{OCH}_{3}\right), 35.1\left(\mathrm{~d}, \mathrm{~J}=17, \mathrm{CH}_{2}\right)$.

Reaction of Benzyl Bromide with 1,2-bis(phenylphosphino)ethane $\left(\operatorname{PHPh}\left(\mathrm{CH}_{2}\right)_{2} \mathrm{PHPh}\right)$ in the Absence of a Catalyst To 1,2-bis(phenylphosphino)ethane $(12.3 \mathrm{mg}, 0.05 \mathrm{mmol})$ in $0.2 \mathrm{~mL}$ of THF was added $\mathrm{NaOSiMe}_{3}(11.2 \mathrm{mg}, 0.1 \mathrm{mmol})$ suspended in $0.3 \mathrm{~mL}$ of THF. The reaction mixture was transferred to an NMR tube. Benzyl bromide $(12 \mu \mathrm{L}, 17 \mathrm{mg}, 0.1 \mathrm{mmol})$ was added via microliter syringe, and the reaction mixture was monitored by ${ }^{31} \mathrm{P}$ NMR spectroscopy. No reaction occurred after $30 \mathrm{~min}$.

\section{Catalytic Reaction of Benzyl Bromide with 1,2-bis(phenylphosphino)ethane} $\left(\mathbf{P H P h}\left(\mathbf{C H}_{2}\right)_{2} \mathbf{P H P h}\right)$ To 1,2-bis(phenylphosphino)ethane $(24.6 \mathrm{mg}, 0.1 \mathrm{mmol})$ in $0.1 \mathrm{~mL}$ of $\mathrm{THF}$ was added $\mathrm{NaOSiMe}_{3}(22.4 \mathrm{mg}, 0.2 \mathrm{mmol})$ suspended in $0.2 \mathrm{~mL}$ of THF. The mixture was added to $\mathrm{Pt}((\mathrm{R}, \mathrm{R})-$ i-Pr-Duphos $)(\mathrm{Ph})(\mathrm{Cl})(7.3 \mathrm{mg}, 0.01 \mathrm{mmol})$ as the catalyst precursor $(5 \mathrm{~mol} \%)$ in $0.1 \mathrm{~mL}$ of $\mathrm{THF}$ and the mixture was transferred to an NMR tube fitted with a septum. Benzyl bromide (34 mg, $24 \mu \mathrm{L}, 0.1 \mathrm{mmol})$ was added via a microliter syringe. The reaction mixture was monitored by ${ }^{31} \mathrm{P}$ NMR spectroscopy. An increasing amount of white precipitate was observed as the reaction progressed. The reaction went to completion in less than $5 \mathrm{~min}$. The catalyst and $\mathrm{NaBr}$ were removed from the reaction mixture on a silica column ( $5 \mathrm{~cm}$ height, $0.6 \mathrm{~cm}$ diameter), using a 9:1 petroleum ether:THF mixture as eluent. The catalyst and $\mathrm{NaBr}$ did not elute. The solvent was removed under vacuum and a colorless viscous liquid was obtained (40 mg, 98\% yield, 98\% selectivity (other peaks $=-11.0(\mathrm{~d}, \mathrm{~J}=38), 32.4(\mathrm{~d}, \mathrm{~J}=38)$ ); 48\% de (1:2.8 meso:rac ratio), $86 \%$ ee for the rac isomer. Results with the catalyst precursor $\operatorname{Pt}((\mathrm{R}, \mathrm{R})-\mathrm{Me}-$ 
Duphos $)(\mathrm{Ph})(\mathrm{Cl})$ were similar, but gave the opposite hand of the rac product preferentially. An example of this catalysis at reduced temperature is described below.

Catalytic reaction of benzyl bromide with 1,2-bis(phenylphosphino)ethane at reduced temperature. A Schlenk flask was loaded with1,2-bis(phenylphosphino)ethane (74 mg, $0.3 \mathrm{mmol})$ in 1 mL of THF, $\mathrm{NaOSiMe}_{3}(67 \mathrm{mg}, 0.6 \mathrm{mmol})$ suspended in $1 \mathrm{~mL}$ of THF and $\mathrm{Pt}(\mathrm{Me}-\mathrm{Duphos})(\mathrm{Ph})(\mathrm{Cl})(9.4$ $\mathrm{mg}, 0.015 \mathrm{mmol})$ as the catalyst precursor $(2.5 \mathrm{~mol} \%)$ in $1 \mathrm{~mL}$ of THF, with stirring. The flask was placed into a $\mathrm{NaCl} /$ ice bath at $-5{ }^{\circ} \mathrm{C}$. Benzyl bromide $(103 \mathrm{mg}, 71 \mu \mathrm{L}, 0.6 \mathrm{mmol})$ was added to the reaction mixture via a microliter syringe. An increasing amount of white precipitate was observed as the reaction progressed. After $4 \mathrm{~h}$ the flask was placed in a refrigerator at $-15^{\circ} \mathrm{C}$. After $4 \mathrm{~d}$, the reaction was complete as determined by ${ }^{31} \mathrm{P}$ NMR spectroscopy. The catalyst and $\mathrm{NaBr}$ were removed from the reaction mixture on a silica column ( $5 \mathrm{~cm}$ height, $0.6 \mathrm{~cm}$ diameter), using a 9:1 petroleum ether:THF mixture as eluent. The catalyst and $\mathrm{NaBr}$ did not elute. The solvent was removed under vacuum and $104 \mathrm{mg}$ (81\% yield) of a colorless liquid was obtained. The tertiary phosphine as a mixture of 2 diastereomers $\mathbf{a}$ and $\mathbf{b}$ (ratio $\mathbf{a}: \mathbf{b}=$ 1:2.8) was dissolved in $0.5 \mathrm{~mL}$ of $\mathrm{C}_{6} \mathrm{D}_{6}$ for spectroscopic characterization.

The product is a known compound for which we report additional characterization data. ${ }^{17} \mathrm{HRMS} \mathrm{m} / \mathrm{z}$ calcd. for $\mathrm{C}_{28} \mathrm{H}_{29} \mathrm{O}_{2} \mathrm{P}_{2}^{+}\left(\mathrm{MO}_{2} \mathrm{H}^{+}\right)$459.1643. Found, 459.1626. ${ }^{31} \mathrm{P}\left\{{ }^{1} \mathrm{H}\right\} \mathrm{NMR}\left(\mathrm{C}_{6} \mathrm{D}_{6}\right): \delta-13.8(\mathbf{a}),-14.2$ (b) (ratio a:b = 1:2.8, de = 47\%). ${ }^{1} \mathrm{H}$ NMR $\left(\mathrm{C}_{6} \mathrm{D}_{6}\right)$ : $\delta$ 7.32-7.24 (m, 4H, Ar), 7.12-7.00 (m, 10H, Ar), 6.97 (t, J = 7, 2H, Ar), 6.95-6.89 (m, 4H, Ar), 2.81 (AB pattern, $\left.\mathrm{J}=14,2 \mathrm{H}, \mathrm{CH}_{2}, \mathbf{a}\right), 2.78$ (AB pattern, $\mathrm{J}=14$, 2H, $\left.\mathrm{CH}_{2}, \mathbf{b}\right), 2.77\left(\mathrm{AB}\right.$ pattern, $\left.\mathrm{J}=14,2 \mathrm{H}, \mathrm{CH}_{2}, \mathbf{a}\right), 2.76\left(\mathrm{AB}\right.$ pattern, $\left.\mathrm{J}=14,2 \mathrm{H}, \mathrm{CH}_{2}, \mathbf{b}\right), 1.78-1.65(\mathrm{~m}$, $2 \mathrm{H}, \mathrm{CH}_{2}$ ) overlapping with $1.67\left(\mathrm{t}, \mathrm{J}_{\mathrm{P}-\mathrm{H}}=4,2 \mathrm{H}, \mathrm{CH}_{2}\right) \cdot{ }^{13} \mathrm{C}\left\{{ }^{1} \mathrm{H}\right\} \mathrm{NMR}\left(\mathrm{C}_{6} \mathrm{D}_{6}\right): \delta$ 138.7-138.4 (m, quat), 133.7-133.2 (m, Ar), 129.84-129.78 (m, Ar), 129.49 (b), 129.46 (a), 129.0-128.8 (m, Ar), 126.4-126.3 (m, Ar), $37.0\left(\mathrm{dd}, \mathrm{J}=18,11, \mathrm{CH}_{2}, \mathbf{b}\right), 36.6\left(\mathrm{dd}, \mathrm{J}=18,10, \mathrm{CH}_{2}, \mathbf{a}\right), 23.89-23.8\left(\mathrm{~m}, \mathrm{CH}_{2}, \mathbf{a}\right), 23.8-23.7\left(\mathrm{~m}, \mathrm{CH}_{2}\right.$, b).

The ee of the diphosphine could be determined using (S)- $\left\{\mathrm{Pd}\left[\mathrm{NMe}_{2} \mathrm{CH}(\mathrm{Me})\left(\mathrm{C}_{6} \mathrm{H}_{4}\right)\right](\mu-\mathrm{Cl})\right\}_{2}$ (see Table 1) or the naphthyl analogue $(\mathrm{S})-\left\{\mathrm{Pd}\left[\mathrm{NMe}_{2} \mathrm{CH}(\mathrm{Me})\left(\mathrm{C}_{10} \mathrm{H}_{6}\right)\right](\mu-\mathrm{Cl})\right\}_{2}$. For example, when the latter was used, $(\mathrm{Ph})\left(\mathrm{PhCH}_{2}\right) \mathrm{PCH}_{2} \mathrm{CH}_{2} \mathrm{P}(\mathrm{Ph})\left(\mathrm{CH}_{2} \mathrm{Ph}\right)(13 \mathrm{mg}, 0.03 \mathrm{mmol})$ and the naphthylamine-Pd complex (20 $\mathrm{mg}, 0.03 \mathrm{~mol})$ were dissolved in $0.5 \mathrm{~mL}$ of $\mathrm{CD}_{2} \mathrm{Cl}_{2} \cdot{ }^{31} \mathrm{P}\left\{{ }^{1} \mathrm{H}\right\}$ NMR $\left(\mathrm{CD}_{2} \mathrm{Cl}_{2}\right): \delta 37.5\left(\mathbf{b}_{1}\right), 35.5$ (overlapping $\left.\mathbf{a}_{\mathbf{1}}+\mathbf{a}_{2}\right), 35.2\left(\mathbf{b}_{2}\right)$, ratio $\mathbf{a}: \mathbf{b}=1: 2.7$, where $\mathbf{a}$ is the meso diastereomer; ratio $\mathbf{b}_{\mathbf{1}}: \mathbf{b}_{2}=1: 22.3$, $91 \%$ ee for $\mathbf{b}))$. 


\section{Reaction of Benzyl Bromide with 1,2-bis(phenylphosphino)propane $\left(\mathrm{PHPh}\left(\mathrm{CH}_{2}\right)_{3} \mathrm{PHPh}\right)$ in}

the Absence of a Catalyst To 1,2-bis(phenylphosphino)propane (13 mg, $0.05 \mathrm{mmol}$ ) in $0.2 \mathrm{~mL}$ of THF was added $\mathrm{NaOSiMe}_{3}(11.2 \mathrm{mg}, 0.1 \mathrm{mmol})$ suspended in $0.3 \mathrm{~mL}$ of THF. The reaction mixture was transferred to an NMR tube. Benzyl bromide (12 $\mu \mathrm{L}, 17 \mathrm{mg}, 0.1 \mathrm{mmol})$ was added via microliter syringe, and the reaction mixture was monitored by ${ }^{31} \mathrm{P}$ NMR spectroscopy. Formation of a white precipitate was observed as the reaction progressed. After $30 \mathrm{~min}$ the conversion was $11 \%$ and the selectivity $24 \%$ (other peak $\delta$-10.8).

\section{Catalytic Reaction of Benzyl Bromide with 1,2-bis(phenylphosphino)propane} $\left(\mathbf{P H P h}\left(\mathbf{C H}_{2}\right)_{3} \mathbf{P H P h}\right)$ To 1,2-bis(phenylphosphino)propane (26 mg, $\left.0.1 \mathrm{mmol}\right)$ in $0.1 \mathrm{~mL}$ of THF was added $\mathrm{NaOSiMe}_{3}(22.4 \mathrm{mg}, 0.2 \mathrm{mmol})$ suspended in $0.2 \mathrm{~mL}$ of THF. The mixture was added to $\mathrm{Pt}(\mathrm{Me}-$ Duphos $)(\mathrm{Ph})(\mathrm{Cl})(6.2 \mathrm{mg}, 0.01 \mathrm{mmol})$ as the catalyst precursor $(5 \mathrm{~mol} \%)$ in $0.1 \mathrm{~mL}$ of THF. The reaction mixture was transferred to an NMR tube. Benzyl bromide (34 mg, $24 \mu \mathrm{L}, 0.2 \mathrm{mmol}$ ) was added via a microliter syringe. The reaction mixture was monitored by ${ }^{31} \mathrm{P} \mathrm{NMR}$ spectroscopy. An increasing amount of white precipitate was observed as the reaction progressed. The reaction went to completion in less than 5 min. The catalyst and $\mathrm{NaBr}$ were removed from the reaction mixture on a silica column $(5 \mathrm{~cm}$ height, 0.6 cm diameter), using a 9:1 petroleum ether:THF mixture as eluent. The catalyst and $\mathrm{NaBr}$ did not elute. The solvent was removed under vacuum and $39 \mathrm{mg}$ (87\% yield) of a colorless liquid was obtained. The tertiary phosphine as a mixture of 2 diastereomers $\mathbf{a}$ and $\mathbf{b}$ (ratio a:b (meso/rac) $=1: 3.9)$ was dissolved in $0.5 \mathrm{~mL}$ of $\mathrm{C}_{6} \mathrm{D}_{6}$ for spectroscopic characterization.

The product is a known compound for which we report additional characterization data. ${ }^{18} \quad{ }^{31} \mathrm{P}\left\{{ }^{1} \mathrm{H}\right\}$ $\operatorname{NMR}\left(\mathrm{C}_{6} \mathrm{D}_{6}\right): \delta-19.0(\mathbf{a}),-19.2$ (b) (lit. $\left.-18.6,-19.4\right)$; ratio a:b = 1:3.9, de = 59\%) (selectivity $\left.100 \%\right)$. ${ }^{13} \mathrm{C}\left\{{ }^{1} \mathrm{H}\right\} \operatorname{NMR}\left(\mathrm{C}_{6} \mathrm{D}_{6}\right): \delta 139.1(\mathrm{~d}, \mathrm{~J}=18$, meso), $139.0(\mathrm{~d}, \mathrm{~J}=19$, rac), 138.6 (d, J = 5, overlapping rac/meso), $133.31(\mathrm{~d}, \mathrm{~J}=19, \mathrm{rac}), 133.30$ ( $\mathrm{d}, \mathrm{J}=19$, meso), $129.8(\mathrm{~d}, \mathrm{~J}=6$, overlapping rac/meso), 129.4 (meso), 129.3 (rac), 128.9-128.8 (m, overlapping rac/meso), 126.4-126.3 (m, overlapping rac/meso), 37.0 (d, J = 17, $\mathrm{P}-\mathrm{CH}_{2} \mathrm{Ph}, \mathrm{rac}$ ), 36.9 (d, J = 17, P- $\mathrm{CH}_{2} \mathrm{Ph}$, meso), 29.3-29.1 (m, $\mathrm{P}-\mathrm{CH}_{2}$, overlapping rac/meso), $23.0\left(\mathrm{t}, \mathrm{J}=16, \mathrm{CH}_{2}\right.$, overlapping rac/meso). ${ }^{1} \mathrm{H}$ NMR $\left(\mathrm{C}_{6} \mathrm{D}_{6}\right): \delta$ 7.35-7.29 (m, 4H), 7.09-7.05 (m, 10H), 7.00-6.95 (m, 6H), $2.84\left(1 \mathrm{H}, \mathrm{AB}\right.$ pattern, $\left.\mathrm{J}=13, \mathrm{CH}_{2} \mathrm{Ph}, \mathrm{rac}\right), 2.79\left(1 \mathrm{H}, \mathrm{AB}\right.$ pattern, $\left.\mathrm{J}=13, \mathrm{CH}_{2} \mathrm{Ph}, \mathrm{rac}\right)$, $2.82\left(1 \mathrm{H}, \mathrm{AB}\right.$ pattern, $\mathrm{J}=14, \mathrm{CH}_{2} \mathrm{Ph}$, meso), $2.79\left(1 \mathrm{H}, \mathrm{AB}\right.$ pattern, $\mathrm{J}=14, \mathrm{CH}_{2} \mathrm{Ph}$, meso), 1.69-1.53 (m, $\left.4 \mathrm{H}, \mathrm{CH}_{2}, \mathrm{rac}+\mathrm{meso}\right), 1.50-1.42\left(\mathrm{~m}, 2 \mathrm{H}, \mathrm{CH}_{2}, \mathrm{rac}+\mathrm{meso}\right)$. 
The ee was determined using the general method $\left({ }^{31} \mathrm{P}\left\{{ }^{1} \mathrm{H}\right\} \operatorname{NMR}\left(\mathrm{C}_{6} \mathrm{D}_{6}\right): \delta 35.3\left(\mathbf{b}_{1}\right), 34.9\left(\mathbf{a}_{1}\right), 31.3\right.$ $\left(\mathbf{a}_{2}\right), 28.3\left(\mathbf{b}_{\mathbf{2}}\right)$, ratio $\mathbf{a}: \mathbf{b}=1: 4$, ratio $\mathbf{a}_{1}: \mathbf{a}_{2}=1.1: 1$, a-meso diastereomer, ratio $\mathbf{b}_{1}: \mathbf{b}_{2}=1: 25.7,93 \%$ ee for b)).

\section{Reaction of $\alpha, \alpha^{\prime}$-Dibromo-m-xylene with PHMe(Is) in the Absence of a Catalyst To PHMe(Is)} (50 mg, $0.2 \mathrm{mmol})$ in $0.1 \mathrm{~mL}$ of toluene was added $\mathrm{NaOSiMe}_{3}(22.4 \mathrm{mg}, 0.2 \mathrm{mmol})$ suspended in $0.2 \mathrm{~mL}$ of toluene and $\alpha, \alpha$ '-dibromo- $m$-xylene $(26.3 \mathrm{mg}, 0.1 \mathrm{mmol})$ in $0.1 \mathrm{~mL}$ of toluene. The reaction mixture was transferred to an NMR tube and monitored by ${ }^{31} \mathrm{P}$ NMR spectroscopy. Formation of a white precipitate was observed as the reaction progressed. After 1 week, conversion was $\sim 49 \%$ and selectivity $45 \%$ (other peaks $\delta 35.4,34.7,34.6,34.5,-53.2,-55.4,-58.7,-83.6,-84.2$ ).

Catalytic Reaction of $\boldsymbol{\alpha}, \boldsymbol{\alpha}^{\prime}$-Dibromo-m-xylene with PHMe(Is). To PHMe(Is) (50 mg, 0.2 mmol) in $0.1 \mathrm{~mL}$ of toluene was added $\mathrm{NaOSiMe}_{3}(22.4 \mathrm{mg}, 0.2 \mathrm{mmol})$ suspended in $0.2 \mathrm{~mL}$ of toluene. The mixture was added to $\mathrm{Pt}(\mathrm{Me}-\mathrm{Duphos})(\mathrm{Ph})(\mathrm{PMeIs})(8.3 \mathrm{mg}, 0.01 \mathrm{mmol})$ as the catalyst precursor (5 $\mathrm{mol} \%)$ in $0.1 \mathrm{~mL}$ of toluene and $\alpha, \alpha^{\prime}$-dibromo- $m$-xylene $(26.3 \mathrm{mg}, 0.1 \mathrm{mmol})$ in $0.1 \mathrm{~mL}$ of toluene. The reaction mixture was transferred to an NMR tube, and the reaction mixture was monitored by ${ }^{31} \mathrm{P}$ NMR spectroscopy. An increasing amount of white precipitate was observed as the reaction progressed. The reaction went to completion in $\sim 24 \mathrm{~h}$. In addition to the desired product, peaks due to impurities were observed at $\delta 41.4,40.2,38.9,-39.9,-40.1$, and -40.5 .

The catalyst, $\mathrm{NaBr}$ and some of the impurities were removed from the reaction mixture on a silica column (14 cm height, $1 \mathrm{~cm}$ diameter), using a 9:1 petroleum ether:THF mixture as eluent. The catalyst, $\mathrm{NaBr}$ and some of the impurities did not elute. The solvent was removed under vacuum, and $52 \mathrm{mg}(86 \%$ yield) of a colorless liquid was obtained. It was dissolved in $0.5 \mathrm{~mL}$ of $\mathrm{C}_{6} \mathrm{D}_{6}$ for spectroscopic characterization.

HRMS m/z calcd. for $\mathrm{C}_{40} \mathrm{H}_{61} \mathrm{P}_{2}^{+}\left(\mathrm{MH}^{+}\right)$603.4249. Found, 603.4227. The following NMR spectra are reported as a mixture of two diastereomers $\mathbf{a}$ and $\mathbf{b}(\mathbf{a}: \mathbf{b}$ (rac:meso) $=3.4: 1,55 \%$ de) unless otherwise indicated. ${ }^{31} \mathrm{P}\left\{{ }^{1} \mathrm{H}\right\}$ NMR $\left(\mathrm{C}_{6} \mathrm{D}_{6}\right): \delta-40.3(\mathbf{a}),-40.6$ (b) (selectivity 87\%, other peaks $\delta-39.7,-40.5$ (major impurity, ca. $10 \%$ of the mixture $),-41.0) .{ }^{1} \mathrm{H}$ NMR $\left(\mathrm{C}_{6} \mathrm{D}_{6}\right): \delta 7.08-7.06(\mathrm{~m}, 1 \mathrm{H}, \mathrm{Ar}), 7.05\left(\mathrm{~d}, \mathrm{~J}_{\mathrm{P}-\mathrm{H}}=2,4 \mathrm{H}\right.$, Is, b), $7.04\left(\mathrm{~d}, \mathrm{~J}_{\mathrm{P}-\mathrm{H}}=2,4 \mathrm{H}, \mathrm{Is}, \mathbf{a}\right), 6.98(\mathrm{~d}, \mathrm{~J}=1,2 \mathrm{H}, \mathrm{Ar}, \mathbf{a}), 6.96(\mathrm{~d}, \mathrm{~J}=2,2 \mathrm{H}, \mathrm{Ar}, \mathbf{b}), 6.93(\mathrm{~d}, \mathrm{~J}=2,1 \mathrm{H}, \mathrm{Ar}$, a), $6.91(1 \mathrm{H}, \mathrm{Ar}, \mathbf{b}), 4.10-4.00(\mathrm{~m}, 4 \mathrm{H}, \mathrm{CH}, i-\mathrm{Pr}), 3.20\left(\mathrm{dd}, \mathrm{J}_{\mathrm{P}-\mathrm{H}}=2, \mathrm{~J}=14,1 \mathrm{H}, \mathrm{CH}_{2}, \mathbf{b}\right), 3.16\left(\mathrm{dd}, \mathrm{J}_{\mathrm{P}-\mathrm{H}}=2\right.$, $\left.\mathrm{J}=14,1 \mathrm{H}, \mathrm{CH}_{2}, \mathbf{a}\right), 3.10\left(\mathrm{~d}, \mathrm{~J}=14,1 \mathrm{H}, \mathrm{CH}_{2}, \mathbf{a}+\mathbf{b}\right.$ overlapping), 2.75-2.64 (m, 2H, CH, $\left.i-\mathrm{Pr}\right), 1.34\left(\mathrm{~d}, \mathrm{~J}_{\mathrm{P}-\mathrm{H}}\right.$ 
$=7,6 \mathrm{H}, \mathrm{P}-\mathrm{Me}, \mathbf{b}), 1.30\left(\mathrm{~d}, \mathrm{~J}_{\mathrm{P}-\mathrm{H}}=7,6 \mathrm{H}, \mathrm{P}-\mathrm{Me}, \mathbf{a}\right), 1.26\left(\mathrm{~d}, \mathrm{~J}=7,12 \mathrm{H}, \mathrm{CH}_{3}, \mathbf{b}\right), 1.25\left(\mathrm{~d}, \mathrm{~J}=7,12 \mathrm{H}, \mathrm{CH}_{3}, \mathbf{a}\right)$, $1.16\left(\mathrm{~d}, \mathrm{~J}=7,12 \mathrm{H}, \mathrm{CH}_{3}, \mathbf{b}\right), 1.15\left(\mathrm{~d}, \mathrm{~J}=7,12 \mathrm{H}, \mathrm{CH}_{3}, \mathbf{a}\right), 1.12-1.10\left(\mathrm{~m}, 12 \mathrm{H}, \mathrm{CH}_{3}, \mathbf{a}+\mathbf{b}\right) .{ }^{13} \mathrm{C}\left\{{ }^{1} \mathrm{H}\right\} \mathrm{NMR}$ $\left(\mathrm{C}_{6} \mathrm{D}_{6}\right): \delta 156.3$ (d, $\mathrm{J}=13$, quat, b), 156.2 (d, $\mathrm{J}=14$, quat, b), 150.8 (quat), 140.3 (dd, $\mathrm{J}=10,3$, quat, Ar), $131.2(\mathrm{~d}, \mathrm{~J}=26, \mathbf{b}), 131.1$ (d, J = 26, a), 130.7 (t, J = 6, Ar), 130.6 (d, J = 7, Ar), 129.1 (m, Ar), 128.9 (m, Ar), 127.3-127.2 (m, Ar), 126.9 (d, J = 6, Ar), 122.8 (Ar), 122.6 (d, J = 4, Is), 37.2 (d, J = 19, CH, $i-\operatorname{Pr}, \mathbf{a})$, $37.1(\mathrm{~d}, \mathrm{~J}=19, \mathrm{CH}, i-\operatorname{Pr}, \mathbf{b}), 35.01(\mathrm{CH}, i-\mathrm{Pr}, \mathbf{b}), 34.99(\mathrm{CH}, i-\operatorname{Pr}, \mathbf{a}), 31.9\left(\mathrm{~d}, \mathrm{~J}=21, \mathrm{CH}_{2}, \mathbf{b}\right), 31.8(\mathrm{~d}, \mathrm{~J}=$ 21, $\left.\mathrm{CH}_{2}, \mathbf{a}\right), 25.50\left(\mathrm{CH}_{3}, \mathbf{b}\right), 25.49\left(\mathrm{CH}_{3}, \mathbf{a}\right), 25.4\left(\mathrm{CH}_{3}, \mathbf{a}\right), 24.8\left(\mathrm{CH}_{3}, \mathbf{b}\right), 24.44\left(\mathrm{CH}_{3}, \mathbf{a}\right), 24.45\left(\mathrm{CH}_{3}, \mathbf{b}\right)$, 11.92 (d, J = 22, P-Me, b), 11.88 (d, J = 21, P-Me, a). The ee was determined using the general method $\left({ }^{31} \mathrm{P}\left\{{ }^{1} \mathrm{H}\right\} \operatorname{NMR}\left(\mathrm{C}_{6} \mathrm{D}_{6}\right): \delta 15.0\left(\mathbf{b}_{1}\right), 14.1\left(\mathbf{b}_{2}\right), 14.0\left(\mathbf{a}_{1}\right), 12.2\left(\mathbf{a}_{2}\right)\right.$, ratio a:b = 3.8:1, ratio $\mathbf{a}_{1}: \mathbf{a}_{2}=1: 5.4$, $69 \%$ ee for $\mathbf{a}, \mathbf{b}$-meso diastereomer, ratio $\left.\mathbf{b}_{1}: \mathbf{b}_{2}=1: 1\right)$.

Reaction of 2,6-bis(bromomethyl)pyridine with PHMe(Is) in the absence of a catalyst. To PHMe(Is) (25 mg, $0.1 \mathrm{mmol})$ in $0.1 \mathrm{~mL}$ of toluene was added $\mathrm{NaOSiMe}_{3}(11.2 \mathrm{mg}, 0.1 \mathrm{mmol})$ suspended in $0.2 \mathrm{~mL}$ of toluene and 2,6-bis(bromomethyl)pyridine $(13.2 \mathrm{mg}, 0.05 \mathrm{mmol})$ in $0.1 \mathrm{~mL}$ of toluene. The reaction mixture was transferred to an NMR tube and monitored by ${ }^{31} \mathrm{P}$ NMR spectroscopy. Formation of a white precipitate was observed as the reaction progressed. After 4 d, conversion was ca. $22 \%$ and selectivity $52 \%$ (other peaks $\delta 38.4,-40.6,-41.4,-53.1,-56.2$ ).

Catalytic reaction of 2,6-bis(bromomethyl)pyridine with PHMe(Is). To PHMe(Is) (50 mg, 0.2 mmol) in $0.1 \mathrm{~mL}$ of toluene was added $\mathrm{NaOSiMe}_{3}(22.4 \mathrm{mg}, 0.2 \mathrm{mmol})$ suspended in $0.2 \mathrm{~mL}$ of toluene. The mixture was added to $\mathrm{Pt}(\mathrm{Me}-\mathrm{Duphos})(\mathrm{Ph})(\mathrm{PMeIs})(8.3 \mathrm{mg}, 0.01 \mathrm{mmol})$ as the catalyst precursor $(5$ $\mathrm{mol} \%$ ) in $0.1 \mathrm{~mL}$ of toluene and 2,6-bis(bromomethyl)pyridine (26.4 mg, $0.1 \mathrm{mmol})$ in $0.1 \mathrm{~mL}$ of toluene. The reaction mixture was transferred to an NMR tube and monitored by ${ }^{31} \mathrm{P}$ NMR spectroscopy. An increasing amount of white precipitate was observed as the reaction progressed. The reaction went to completion in $\sim 1 \mathrm{~d}$. Formation of impurities ( $\delta 40.3,40.1,39.9,39.7,38.9,38.4,13 \%$ total) was observed. The catalyst, impurities and $\mathrm{NaBr}$ were removed from the reaction mixture on a silica column $(5 \mathrm{~cm}$ height, $0.6 \mathrm{~cm}$ diameter), using a 9:1 petroleum ether:THF mixture as eluent. The catalyst, impurities, and $\mathrm{NaBr}$ did not elute. The solvent was removed under vacuum and $55 \mathrm{mg}$ (90\% yield) of colorless liquid was obtained. The phosphine was dissolved in $0.5 \mathrm{~mL}$ of $\mathrm{C}_{6} \mathrm{D}_{6}$ for spectroscopic characterization.

HRMS m/z calcd. for $\mathrm{C}_{39} \mathrm{H}_{60} \mathrm{NP}_{2} \mathrm{O}_{2}{ }^{+}\left(\mathrm{MO}_{2} \mathrm{H}^{+}\right)$636.4099. Found, 636.4083. The mono-oxidized and protonated product was also observed: $\mathrm{m} / \mathrm{z} 620.4127$ (calcd. for $\mathrm{C}_{39} \mathrm{H}_{60} \mathrm{NP}_{2} \mathrm{O}^{+}\left(\mathrm{MOH}^{+}\right)$620.4150). 
The following NMR spectra are reported as a mixture of two diastereomers $\mathbf{a}$ and $\mathbf{b}(\mathbf{a}: \mathbf{b}=1.4: 1$ (rac/meso), $17 \%$ de) unless otherwise indicated. ${ }^{31} \mathrm{P}\left\{{ }^{1} \mathrm{H}\right\}$ NMR $\left(\mathrm{C}_{6} \mathrm{D}_{6}\right): \delta-40.8(\mathbf{a}),-40.9$ (b) (selectivity $90 \%$, other peak $\delta-41.4) .{ }^{1} \mathrm{H}$ NMR $\left(\mathrm{C}_{6} \mathrm{D}_{6}\right): \delta 7.12\left(\mathrm{~d}, \mathrm{~J}_{\mathrm{P}-\mathrm{H}}=2,4 \mathrm{H}, \mathrm{Is}, \mathbf{b}\right), 7.10\left(\mathrm{~d}, \mathrm{~J}_{\mathrm{P}-\mathrm{H}}=2,4 \mathrm{H}, \mathrm{Is}, \mathbf{a}\right), 7.03-$ $6.94(\mathrm{~m}, 1 \mathrm{H}, \mathrm{Ar}), 6.83\left(\mathrm{t}, \mathrm{J}_{\mathrm{P}-\mathrm{H}}=1,1 \mathrm{H}, \mathrm{Ar}, \mathbf{a}\right), 6.81\left(\mathrm{t}, \mathrm{J}_{\mathrm{P}-\mathrm{H}}=2,1 \mathrm{H}, \mathrm{Ar}, \mathbf{b}\right), 6.77\left(\mathrm{t}, \mathrm{J}_{\mathrm{P}-\mathrm{H}}=2,1 \mathrm{H}, \mathrm{Ar}, \mathbf{a}\right), 6.75(\mathrm{t}$, $\left.\mathrm{J}_{\mathrm{P}-\mathrm{H}}=2,1 \mathrm{H}, \mathrm{Ar}, \mathbf{b}\right), 4.22-4.14\left(\mathrm{~m}, 4 \mathrm{H}, \mathrm{CH}, i\right.$-Pr), $3.65\left(\mathrm{~d}, \mathrm{~J}=13,1 \mathrm{H}, \mathrm{CH}_{2}, \mathbf{b}\right), 3.59$ (d, J = 13, 1H, $\left.\mathrm{CH}_{2}, \mathbf{a}\right)$, $3.37\left(\mathrm{dd}, \mathrm{J}=13, \mathrm{~J}_{\mathrm{PH}}=2,1 \mathrm{H}, \mathrm{CH}_{2}, \mathbf{a}\right), 3.32\left(\mathrm{dd}, \mathrm{J}=13, \mathrm{~J}_{\mathrm{PH}}=2,1 \mathrm{H}, \mathrm{CH}_{2}, \mathbf{b}\right), 2.82-2.70(\mathrm{~m}, 2 \mathrm{H}, \mathrm{CH}, i-\mathrm{Pr})$, $1.58\left(\mathrm{~d}, \mathrm{~J}=7,3 \mathrm{H}, \mathrm{P}-\mathrm{CH}_{3}, \mathbf{b}\right), 1.45\left(\mathrm{~d}, \mathrm{~J}=7,3 \mathrm{H}, \mathrm{P}_{-} \mathrm{CH}_{3}, \mathbf{a}\right), 1.33\left(\mathrm{~d}, \mathrm{~J}=7,12 \mathrm{H}, \mathrm{CH}_{3}, \mathbf{a}\right), 1.32(\mathrm{~d}, \mathrm{~J}=7$, $\left.12 \mathrm{H}, \mathrm{CH}_{3}, \mathbf{b}\right), 1.26-1.21\left(\mathrm{~m}, 12 \mathrm{H}, \mathrm{CH}_{3}\right), 1.18\left(\mathrm{~d}, \mathrm{~J}=7,12 \mathrm{H}, \mathrm{CH}_{3}, \mathbf{b}\right), 1.17\left(\mathrm{~d}, \mathrm{~J}=7,12 \mathrm{H}, \mathrm{CH}_{3}, \mathbf{a}\right)$. ${ }^{13} \mathrm{C}\left\{{ }^{1} \mathrm{H}\right\} \operatorname{NMR}\left(\mathrm{C}_{6} \mathrm{D}_{6}\right): \delta 160.4(\mathrm{~d}, \mathrm{~J}=11$, quat, b), $160.3(\mathrm{~d}, \mathrm{~J}=12$, quat, a), $156.2(\mathrm{~d}, \mathrm{~J}=14$, quat, $\mathbf{a}+\mathbf{b}$ overlapping), 150.8 (dd, J = 5, 1, quat), 136.7 (m, Ar), 136.5 (Ar), 131.7 (d, J = 26, Ar), 131.5 (d, J = 26, Ar), 122.7 (Ar), 122.6 (d, J = 4, Is), 120.8-120.6 (m, Ar), 120.5-120.4 (m, Ar), 39.7 (d, J = 19, CH, $i$-Pr, a), 39.6 (d, J = 19, CH, $i$-Pr, b), 35.1 (CH, $i$-Pr, b), 35.0 (d, J = 3, CH, $i$-Pr, a), 31.92 (d, J = 22, $\left.\mathrm{CH}_{2}, \mathbf{b}\right), 31.88$ $\left(\mathrm{d}, \mathrm{J}=22, \mathrm{CH}_{2}, \mathbf{a}\right), 25.52\left(\mathrm{CH}_{3}, \mathbf{b}\right), 25.51\left(\mathrm{CH}_{3}, \mathbf{a}\right), 25.4\left(\mathrm{CH}_{3}, \mathbf{a}\right), 25.39\left(\mathrm{CH}_{3}, \mathbf{b}\right), 24.8\left(\mathrm{CH}_{3}, \mathbf{b}\right), 24.4$ $\left(\mathrm{CH}_{3}, \mathbf{a}\right), 12.1$ (d, J = 21, P-Me, b), 12.0 (d, J = 21, P-Me, a).

The ee was determined using the general method: $\left({ }^{31} \mathrm{P}\left\{{ }^{1} \mathrm{H}\right\} \operatorname{NMR}\left(\mathrm{C}_{6} \mathrm{D}_{6}\right): \delta 14.3\left(\mathbf{a}_{1}\right), 13.3\left(\mathbf{a}_{\mathbf{2}}\right), 12.5\right.$ $\left(\mathbf{b}_{1}\right), 12.2\left(\mathbf{b}_{2}\right)$, ratio $\mathbf{a}: \mathbf{b}=1.4: 1$, ratio $\mathbf{a}_{1}: \mathbf{a}_{2}=6.2: 1,72 \%$ ee for $\mathbf{a}, \mathbf{b}$-meso diastereomer, ratio $\mathbf{b}_{1}: \mathbf{b}_{2}=$ $1.1: 1)$.

\section{References}

1. Pangborn, A. B.; Giardello, M. A.; Grubbs, R. H.; Rosen, R. K.; Timmers, F. J. Organometallics 1996, $15,1518-1520$.

2. Clark, H. C.; Manzer, L. E. J. Organomet. Chem. 1973, 59, 411-428.

3. Wicht, D. K.; Zhuravel, M. A.; Gregush, R. V.; Glueck, D. S.; Guzei, I. A.; Liable-Sands, L. M.; Rheingold, A. L. Organometallics 1998, 17, 1412-1419. 
4. Brunker, T. J.; Blank, N. F.; Moncarz, J. R.; Scriban, C.; Anderson, B. J.; Glueck, D. S.; Zakharov, L. N.; Golen, J. A.; Sommer, R. D.; Incarvito, C. D.; Rheingold, A. L. Organometallics 2005, 24, 2730-2746.

5. Scriban, C.; Wicht, D. K.; Glueck, D. S.; Zakharov, L. N.; Rheingold, A. L., submitted for publication.

6. Wicht, D. K.; Kovacik, I.; Glueck, D. S.; Liable-Sands, L. M.; Incarvito, C. D.; Rheingold, A. L. Organometallics 1999, 18, 5141-5151.

7. Otsuka, S.; Nakamura, A.; Kano, T.; Tani, K. J. Am. Chem. Soc. 1971, 93, 4301-4303.

8. Drago, D.; Pregosin, P. S. Organometallics 2002, 21, 1208-1215.

9. Brauer, D. J.; Bitterer, F.; Dorrenbach, F.; Hessler, G.; Stelzer, O.; Kruger, C.; Lutz, F. Z. Naturforsch. B 1996, 51, 1183-1196.

10. Vedejs, E.; Donde, Y. J. Am. Chem. Soc. 1997, 119, 9293-9294.

11. Ishiyama, T.; Mizuta, T.; Miyoshi, K.; Nakazawa, H. Organometallics 2003, 22, 1096-1105.

12. Blank, N. F. Ph.D. thesis, Dartmouth College, 2005.

13. Kovacik, I.; Wicht, D. K.; Grewal, N. S.; Glueck, D. S.; Incarvito, C. D.; Guzei, I. A.; Rheingold, A. L. Organometallics 2000, 19, 950-953.

14. For protonation of air-sensitive phosphines to give more readily handled air-stable phosphonium salts, see: Netherton, M. R.; Fu, G. C. Org. Lett. 2001, 3, 4295-4298. For related terminal phosphido complexes which could not be isolated in analytically pure form, see: Giner Planas, J.; Hampel, F.; Gladysz, J. A. Chem. Eur. J. 2005, 11, 1402-1416.

15. Payne, N. C.; Stephan, D. W. Can. J. Chem. 1980, 58, 15-21.

16. Albert, J.; Cadena, J. M.; Granell, J.; Muller, G.; Ordinas, J. I.; Panyella, D.; Puerta, C.; Sañudo, C.; Valerga, P. Organometallics 1999, 18, 3511-3518. 
17. Hinton, R. C.; Mann, F. G. J. Chem. Soc. 1959, 2835-2843.

18. (a) Yeh, J. T.; Avens, L. R.; Mills, J. L. Phosphorus, Sulfur and Silicon and the Related Elements 1990, 47, 319-323. (b) Yeh, T.-L. J. Ph.D. Thesis, Texas Tech University, 1987. 